\title{
A Revision of the Sphaeriidae of North America (Mollusca: Pelecypoda)
}

BY

H. B. HERRINGTON

Westbrook, Ontario 


\section{MISCELLANEOUS PUBLICATIONS \\ MUSEUM OF ZOOLOGY, UNIVERSITY OF MICHIGAN}

The publications of the Museum of Zoology, University of Michigan, consist of two series-the Occasional Papers and the Miscellaneous Publications. Both series were founded by Dr. Bryant Walker, Mr. Bradshaw H. Swales, and Dr. W. W. Newcomb.

The Occasional Papers, publication of which was begun in 1913, serve as a medium for original studies based principally upon the collections in the Museum. They are issued separately. When a sufficient number of pages has been printed to make a volume, a title page, table of contents, and an index are supplied to libraries and individuals on the mailing list for the series.

The Miscellaneous Publications, which include papers on field and museum techniques, monographic studies, and other contributions not within the scope of the Occasional Papers, are published separately. It is not intended that they be grouped into volumes. Each number has a title page and, when necessary, a table of contents.

A complete list of publications on Birds, Fishes, Insects, Mammals, Mollusks, and Reptiles and Amphibians is available. Address inquiries to the Director, Museum of Zoology, Ann Arbor, Michigan.

\section{List of Miscellaneous Publications on Mollusks}

No. 6. A synopsis of the classification of the fresh-water Mollusca of North America, North of Mexico, and a catalogue of the more recently described species, with notes. By Bryant Walker. (1918) 213 pp., 1 pl.,

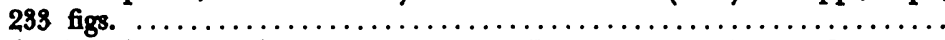

No. 7. The Anculosae of the Alabama River Drainage. By Calvin Goodrick. (1922) 57 pp., 8 pls. . . . . . . . . . $\ldots \ldots \ldots \ldots \ldots \ldots \ldots \ldots \ldots \ldots . \$ 0.75$

No. 12. The genus Gyrotoma. By CAlvin Goodrich. (1924) 29 pp., 2 pls. ..... $\$ 0.50$

No. 18. The terrestrial shell-bearing Mollusca of Alabama. By BRYANT Warker.

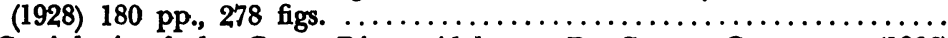

No. 31. Goniobasis of the Coosa River, Alabama. By CALvin Goodrich. (1936)

No. 34. Mollusca of Petén and North Alta Vera Paz, Guatemala. By CALvin GOOdrich and HenRY VAN der Schalme (1937) 50 pp., 1 pl., 1 fig.,

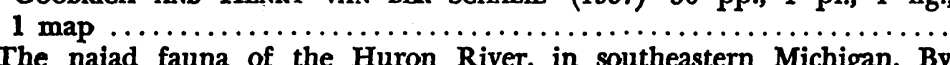

No. 40. The naiad fauna of the Huron River, in southeastern Michigan. By HenRY VAN DER Schalie. (1938) 83 pp., 12 pls., 28 figs., 18 maps ........

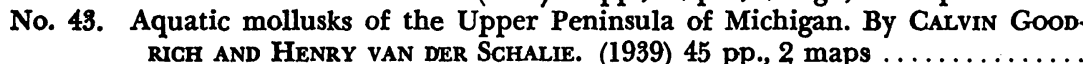

No. 57. The Amnicolidae of Michigan: distribution, ecology, and taxonomy. By EL.MER G. BERRY. (1943) 68 pp., 9 pls., 10 figs., 10 maps .............

No. 60. The fresh-water triclads of Michigan. By Roman Kenk. (1944) 44 pp.,

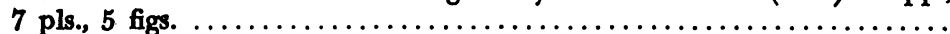

No. 64. Goniobasis livescens of Michigan. By CALvin Goodrich. (1945) 36 pp.,

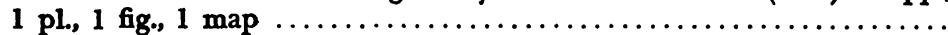

No. 70. The land and fresh-water mollusks of Puerto Rico. By HeNRY van DER Schalre. (1948) 184 pp., 15 pls., 4 figs., 64 maps .................

No. 70. The land and fresh-water mollusks of Puerto Rico. By HENRY VAN DER Schal.w. (1948) 134 pp., 15 pls., 4 figs., 64 maps .................

No. 71. The animal life of temporary and permanent ponds in southern Michigan. By Roman Kenk. (1949) 66 pp., 8 pls., 7 figs., 1 map ..............

No. 89. Anatomy, life history, and evolution of the mites parasitizing fresh-water mussels. By Roger D. Mrtchell. (1955) 28 pp., 6 figs. .............

No. 100. Aspects of the biology of Pomatiopsis lapidaria (Say) (Mollusca: Gastropoda: Prosobranchia). By DEE SAUnders Dunder. (1957) $65 \mathrm{pp}$.,

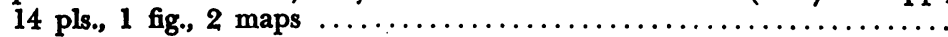

No. 108. The Anatomy of Laevapex fuscus, a freshwater limpet (Gastropoda: Pulmonata). By Paul F. Basch. (1959) 56 pp., 15 figs. .............

No. 118. A Revision of the Sphaeriidae of North America (Mollusca: Pelecypoda). By H. B. Herrington. (1962) 74 pp, 7 plates, 2 figures ............. 


\section{A Revision of the Sphaeriidae of North America (Mollusca: Pelecypoda)}

BY

H. B. HERRINGTON

Westbrook, Ontario 


\section{CONTENTS}

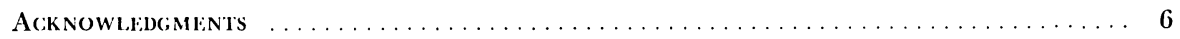

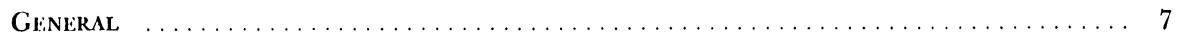

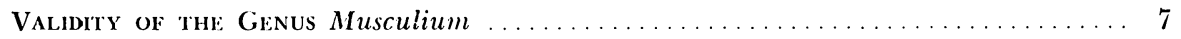

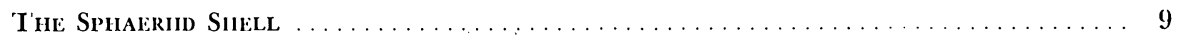

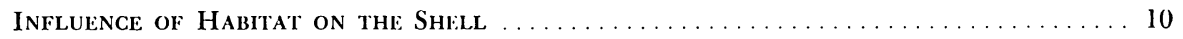

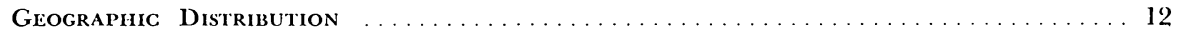

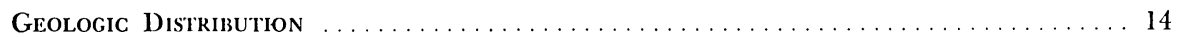

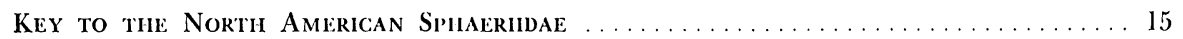

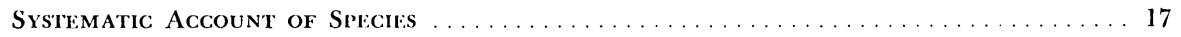

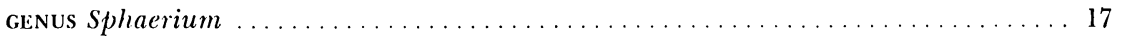

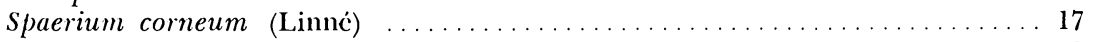

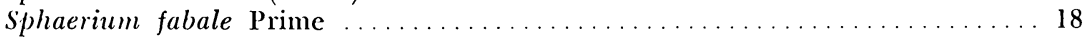

Sphaerium lacustre (Müller) $\ldots \ldots \ldots \ldots \ldots \ldots \ldots \ldots \ldots \ldots \ldots \ldots \ldots \ldots \ldots \ldots \ldots \ldots$

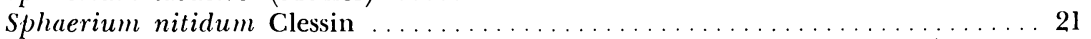

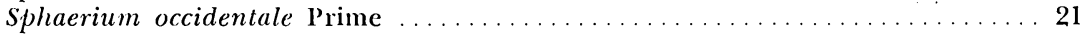

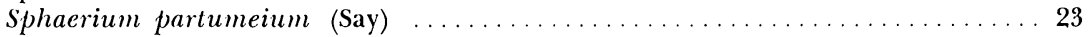

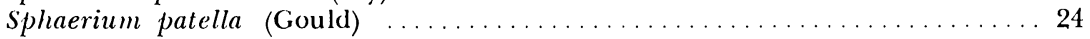

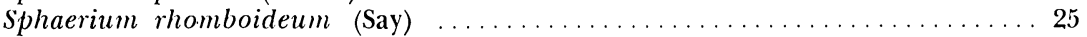

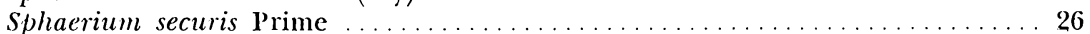

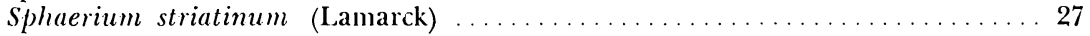

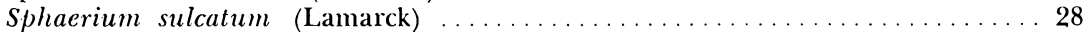

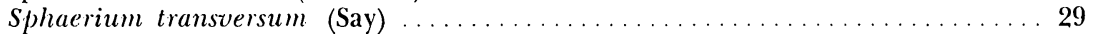

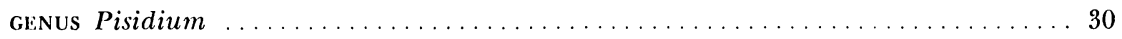

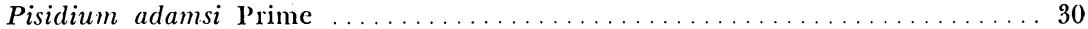

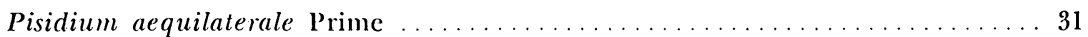

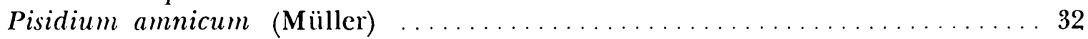

Pisidium casertanum (Poli) ........................... 33

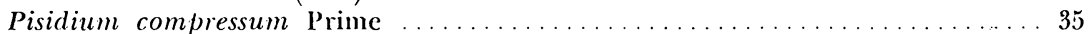

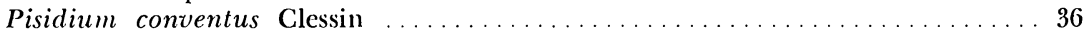

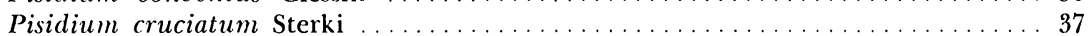

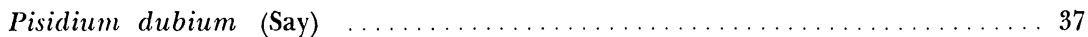

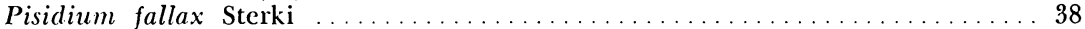

Pisidium ferrugineum Prime ........................... 39

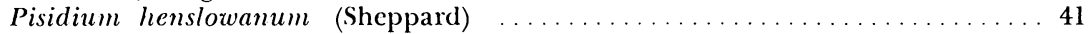

Pisidium idahoense Roper ..............................42

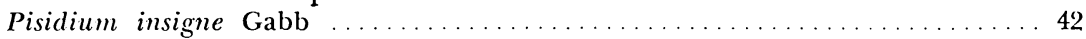

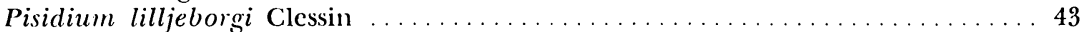

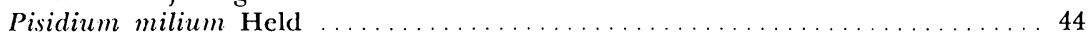

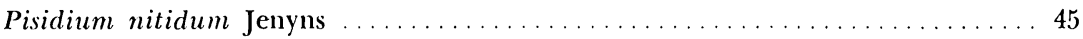

Pisidium obtusale Pfeiffer ..............................46

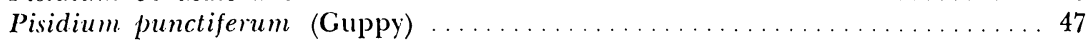

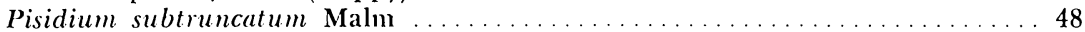

Pisidium ultramontanum Prime ........................49

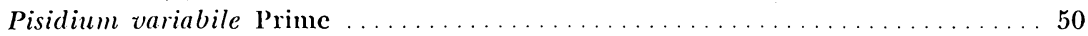

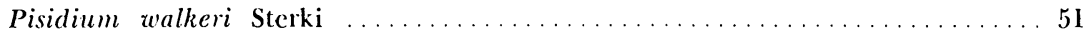

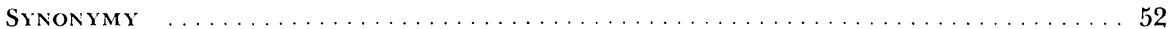

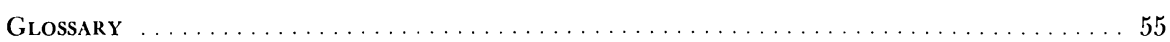

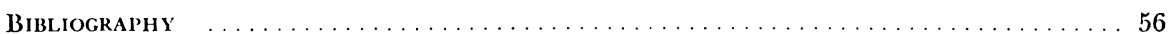




\title{
ILLUSTRATIONS
}

\author{
PLATES
}

(Plates I-VII follow page 74)

I-II. Shells of Sphaerium.

III-VI. Hinges of Pisidium.

VII. Cardinal tecth of Pisidium.

\section{FIGURES IN TEXT}

FIGURE

1. Shells of Sphaerium and Pisidium

2. Hinge teeth terminology 


\section{A REVISION OF THE SPHAERIIDAE OF NORTH AMERICA (MOLLUSCA: PELECYPODA)}

Although the present taxonomy of many groups of North American freshwater mollusks bears evidence of badly needing revision, the systematics of none is in a more chaotic state than that of the sphaeriid clams. These small clams are abundant and widespread, but an understanding of their relationships has been encumbered by the great variation within species and the many names applied to these variants. Because of the existing confusion, identifications are difficult or impossible. Clear-cut descriptions of diagnostic characters which take into account ranges of variation, comparisons of related species, and adequate illustrations are rare, or, more usually, lacking altogether. Furthermore, much of the scattered literature is often inaccessible to many students of mollusks. It is hoped that this publication will not only serve as a long overdue taxonomic revision, but will help make identification a simple matter.

The events and experiences leading up to this publication are as follows: In 1938 the author went to the Royal Ontario Museum of Zoology in Toronto to compare specimens in his personal collection with those the museum had received from Chief Justice Latchford. Most of the specimens in the Latchford collection had been examined, and determinations corroborated, by Victor Sterki, a past authority on these small clams. John Oughton, then at the Royal Ontario Museum, encouraged the author's interest in the sphaeriids, and in 1940 began sending him numerous sets from the Latchford collection.

My contacts with people interested in sphaeriid clams and with museums housing them grew. In 1942 I spent a week studying Sterki's collection at the Carnegie Museum in Pittsburgh. In 1948 ten days were devoted to the Temple Prime (Sterki's predecessor as a sphaeriid authority) collection in the Museum of Comparative Zoology at Harvard University. In 1950 I visited A. W. Stelfox in Dublin, Ireland, and accepted his fine collection for the Museum of Zoology, University of Michigan. While in the British Isles, a month was taken to go over the sphaeriid collection in the British Museum (Natural History). In 1954 a month was devoted to studying the collection in the Academy of Natural Sciences of Philadelphia as an American Philosophical Society Fellow, and in 1959 a month was spent as a consultant in the Museum of Zoology, University of Michigan.

I not only visited these various museums, but also received generous loans from most of them, especially from the Carnegie Museum (Sterki's collection) and from the Museum of Zoology, University of Michigan. 
Specimens were exchanged with a number of collectors, including W. J. Eyerdam, Seattle, Washington, A. E. Ellis, England, J. G. J. Kuiper, the Netherlands, Jules Favre, Geneva, Switzerland, and others. Moreover, many specimens, sent by collectors for determination, from Canada as well as from the United States, were compared with my own extensive collections made in both these countries during the past twenty years.

Consequently, 128 named species, until now commonly arranged under three genera, are consolidated into 34 species under two genera; 13 distinct, apparently ecological, forms are recognized for North America.

The impetus for presenting the present exposition on sphaeriid systematics has been furnished by the many malacologists and students who have encouraged me to publish the assembled information with my ideas on species, relationships, and synonomies in this group of mollusks.

A considerable part of the material on which this investigation is based (the author's own collection, that of Stelfox, and that of the Royal Ontario Museum of Zoology, incorporating Latchford's) have recently been transferred to the Museum of Zoology, University of Michigan. The UMMZ catalog numbers have been quoted in the descriptions of the species.

\section{ACKNOWLEDGMENTS}

Grateful acknowledgment is made to Dr. John Oughton, Department of Entomology and Zoology, Ontario Agricultural College, for guidance and many helpful suggestions during the course of this study, and to Dr. Henry van der Schalie and Dr. John B. Burch, Museum of Zoology, University of Michigan, for encouragement and many kindnesses. The latter prepared the keys and many of the figures, and gave much time and assistance in the preparation of the manuscript. I am also greatly indebted to the several museums and agencies, and the many people who have kindly offered their help during the twenty-odd years I have studied sphaeriid clams. In particular, I wish to acknowledge the cooperation of the Royal Ontario Museum of Zoology and Palaeontology, Toronto; the Museum of Zoology, University of Michigan; the Carnegie Museum, Pittsburgh, Pennsylvania; the Museum of Comparative Zoology, Cambridge, Massachusetts; the British Museum (Natural History), London; the Academy of Natural Sciences of Philadelphia; the National Research Council of Canada; and the American Philosophical Society. Further, I have received assistance from the late Stanley T. Brooks, C. P. Castell, William J. Clench, J. R. Dymond, A. E. Ellis, the late Jules Favre, Robin Fluke, William H. Heard, J. G. J. Kuiper, A. Byron Leonard, Gordon K. MacMillan, Nils $\mathrm{Hj}$. Odhner, Juan Parodiz, the late H. A. Pilsbry, W. J. Rees, Ernest J. Roscoe, A. W. Stelfox, Dwight 
W. Taylor, F. A. Urquart, the late Guy L. Wilkins, and Charles B. Wurtz. Acknowledgment is also due to Arthur Cushman for the illustrations in text Figure 1 and Plate VI, to Herbert Wienert for all photographs, and to Mrs. Anne Gismann for help in editing the manuscript.

\section{GENERAL}

The purpose of this study is to revise the family Sphaeriidae (commonly referred to as fingernail and pea clams) of North America, north of Mexico, using as a basis characters of the shell. While it is desirable to include characters of the soft anatomy of the animals, too little is known at present in a comparative way to utilize such information. Indeed, anatomical characters may in the future change, or strengthen, many of the species concepts presented here. But this revision is desirable, or even necessary, to lay a foundation for such future studies.

The Sphaeriidae have been divided into five genera: Sphaerium, Musculium, Pisidium, Byssanodonta, and Eupera. Most authors, in the past, have considered Eupera to be a synonym of the earlier Byssanodonta. However, according to Klappenbach (1960) these two genera are distinct and well defined, the main characteristic of Byssanodonta being an entirely smooth hinge and the total absence of teeth. Since this genus appears to be limited to South America it does not fall within the scope of this study. Eupera, although records exist for the occurrence of one species in the southern United States, is rare and has not been well studied. For this reason it will not be considered in any detail in this monograph. Instead, I shall deal with the remaining three cosmopolitan genera, the species of which constitute the principal North American sphaeriid fauna. The validity of one genus (Musculium) is questioned and will be discussed in the following section.

Sphaerium and Pisidium are clearly marked genera conchologically and anatomically. In Sphaerium the posterior end of the shell is longer than the anterior end, while in Pisidium just the reverse is true, the anterior end usually being decidedly longer than the posterior (Fig. 1). Sphaerium has a distinct anal and branchial siphon, but in Pisidium only the anal siphon is developed; the branchial siphon is represented by a cleft in the mantle. The siphonal characters of Pisidium were used by Baker (1928) to distinguish a subfamily Pisidiinae from the Sphaeridiinae (comprizing Sphaerium, Musculium, and Eupera).

\section{VALIDITY OF THE GENUS MUSGULIUM}

The genus Musculium is not as clearly defined as Sphaerium and Pisidium. Morphologically it is like Sphaerium and hence the posterior end 


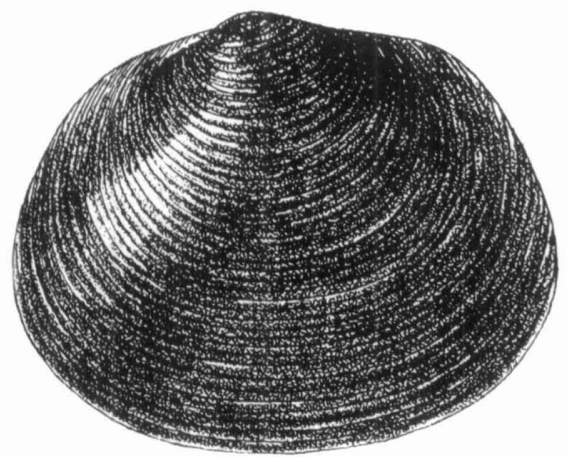

A

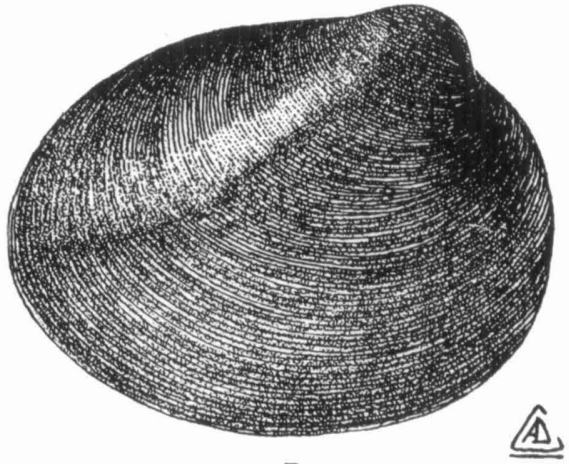

B

Fig. 1. Shells of Sphaerium (A) and Pisidium (B).

of the shell is longer. Spaeriids with such features fall naturally into five groups: (1) striatinum (Lamarck) and sulcatum (Lamarck); (2) corneum (Linné), nitidum Clessin and rhomboideum (Say); (3) patella (Gould) and fabale Prime; (4) occidentale Prime; and (5) lacustre (Müller), partumeium (Say), securis Prime, and transi'ersum (Say).

Group 5 has been given the status of a genus under the name Musculium Link (1807) by various autho!s for the following reasons: their shells have thin walls; the beaks are capped (calyculate); the cardinal teeth are small; and the adults carry a greater number of embryos. However, the species of groups 2 and 4 also have thin walls; the thickness of the shells of Sphaerium nitidum and $S$. occidentale is like that of the average Musculium. Many $M$. partumeium from the southern United States have heavier shells than any $S$. corneum, $S$. nitidum, $S$. occidentale, or $S$. rhomboideum I have ever seen, and heavier than some Michigan S. sulcatum.

All four species of the Musculium group have specimens with capped beaks, but my observations agree with Sterki's diagnosis concerning this character. In 1909 he wrote $(1909 b)$ : “These mussels [Musculium] are described as having their beaks calyculate, or 'capped', and the genus has been established mainly on that feature. But in most and probably in all species, specimens and forms are found with slightly or non-calyculate beaks, and such are the rule rather than the exception in $M$. transversum Say. By the way, it may be said that calyculate beaks are found occasionally in specimens of Pisidium and Sphaerium." Capped beaks are found on some specimens of $P$. casertanum from creeks that dry up in summer. I have frequently found $P$. obtusale form rotundatum with capped beaks. They are common on $S$. nitidum and not uncommon on S. corneum.

The small size of the cardinal teeth of Musculium is in general a con- 
stant character. This feature is associated with narrowness of the hinge. plate. Specimens with a heavy hinge-plate have heavier cardinals. For example, some $M$. partumeium of the southern states have heavier cardinals than I have ever seen in any Sphaerium corneum, S. nitidum, or S. occidentale, and as heavy as in some $S$. sulcatum from northern Michigan or $S$. striatinum from Lake Winnipeg, Manitoba.

Van Cleave, Wright, and Nixon (1947) compared the number of embryos found in Musculium partumeium (8 to 18) with that found in $M$. truncatum (= partumeium) (24; Gilmore, 1917) and Sphaerium solidulum (=striatinum) (2 to 4; Foster, 1932). They concluded that this supported the generic status of Musculium. But my experience shows that the number of embryos in each species of the Musculium group needs to be compared with the number in such species as $S$. corneum, $S$. occidentale, and $S$. rhomboideum before this approach can have much bearing on the validity of Musculium as a genus.

Furthermore, it should be stated here that the shells of the members of each of the groups 1,2, and 3 above are closer in appearance to the other members of their respective group than is Musculium securis to M. transversum.

Therefore, it is my opinion that the so-called genus Musculium is in reality a division of the genus Sphaerium, and cannot be separated on the basis of present information from that genus. In this respect I am in harmony with earlier American and European opinion. If species of the Musculium complex are proven to comprise a distinct group worthy of generic rank it will surely have to be done by a study of the anatomy of the animals. In the meantime it is my intention to treat all the species (four) of this group as Sphaerium.

\section{THE SPHAERIID SHELL}

The shell of sphaeriids as compared with the shells of larger freshwater mussels (Unionidae) is small, often minute, and generally thin. The ligament holding the two valves together is short and not well developed. The pallial line, formed where the mantle attaches to the shell, is indistinct. The muscle scars are also usually obscure. The hinge (Fig. 2) consists of two sets of lateral teeth, one on each valve, and a more or less centrally placed set of cardinal teeth, a set signifying a tongue and groove arrangement, with one pair of teeth on one valve and a single tooth on the opposite valve, to prevent displacement of the valves. There are two pairs of lateral teeth in the right valve and two single laterals in the left, while just the opposite is true concerning the cardinal teeth-two cardinals in the left valve, one in the right. In some specimens the arrangement of teeth is 
reversed; there may be double laterals and a single cardinal in the left valve, and single laterals and two cardinals in the right valve. A more common arrangement in individuals with reversed hinge teeth, however, is to have two laterals at the posterior end of the right valve and one at the anterior end. Other irregularities are also known to occur.

Earlier writers, e.g., Baudon (1857), Prime. (1865), Clessin (1879), Westerlund (1886-90), claimed that Pisidium amnicum and/or P. dubium had two cardinal teeth in each valve, and Clessin established the group Fluminina mainly on the strength of this character. But Sterki (1911) pointed out the error in this concept, and in 1922 elaborated on it: "But it (double cardinals in the right valve) was a misconception, due to careless examination ... this mistaken view has been applied indiscriminately to all species of Pisidium by some authors, e.g., T. Prime, and even to all Sphaeriidae (Prime, '65, pp. 2, 33, 36, etc.), and it was copied, evidently without examining a specimen, by some American writers, e.g. R. E. Call (1900, p. 438 etc.)." This mistake is still being perpetuated (e.g., Clench, 1959).

In order to simplify discussion it has been customary since the time of Bernard (1895-97) to use symbols, especially for the cardinal and lateral teeth, when describing sphaeriid shell characters. These symbols are illustrated in Figure 2.

The various characters of the shell have different values in regard to their usefulness for systematic purposes. In the genus Pisidium the hinge is the most important character to consider. The characteristic outlines of the hingeplates in the various pisidia are shown in Plates III-VI and the shapes of the cardinal teeth in Plate VII. In Sphaerium, however, there is little variation in the hinge between most species. In the latter group the shape of the shell and degree of striation is of prime importance (Pls. I-II). Although the important characters of some species vary but little between individuals and populations, in other species the variation is considerable. In regard to variation, I have usually had in mind the average or typical in describing the diagnostic characters of species treated in the Systematic Account of Species. The descriptive terms used are defined in the glossary, p. 55.

\section{INFLUENCE OF HABITAT ON THE SHELL}

Some information has been gathered on the influence of habitat on such characters as degree of dullness or gloss, coarseness of striae, and size and shape of the shell. In a small creek a few yards above where it empties into Hughes Lake, Lennox and Addington Co., Ontario, Pisidium adamsi has the usual size and shape, but the periostracum is very dull and almost colorless. This may result from a pulpy mass of decaying vegetable matter 
including rotting wood in the bottom of this creek. At the outlet of Irvine Lake into the Mississippi River (seven miles south of the above station) the vegetation for several rods is of rank growth on a hard sandy bottom. Here I collected $P$. adamsi that ranged from the average shape to the short form which Sterki named $P$. sargenti. These were rather dark in color. About four miles farther down stream, in soft sand and vegetable growth, is found the common, dark colored P. adamsi. About a mile below this spot is Mazinaw Lake (I found a depth of 325 feet, and one of 650 feet has been reported) with cool shore water after a strong wind. The bottom near shore is rocky or sandy with a minimum of vegetation. Here $P$. adamsi ranges in size and shape from very close to the average to the small stunted form that Sterki named $P$. deflexum.

I have found that type of bottom affects other species. For example, the specimens of $P$. ferrugineum collected on the sandy bottoms of lakes always,

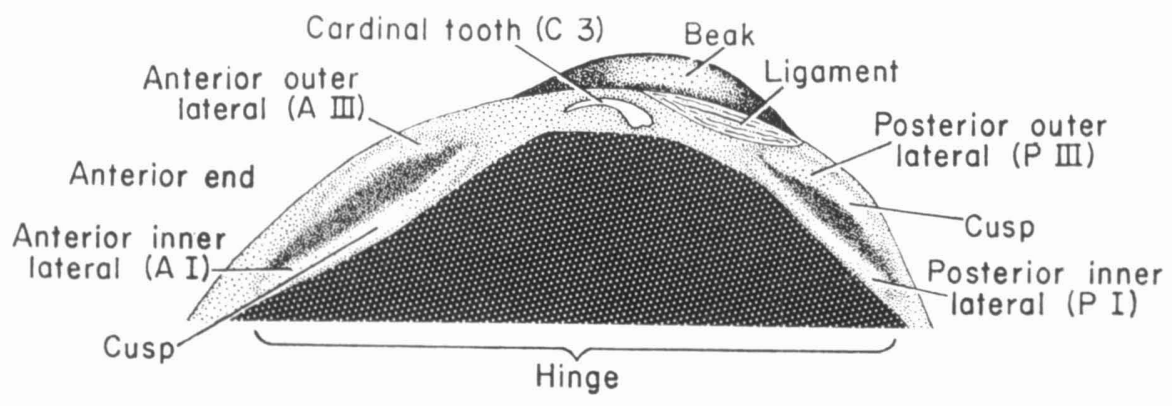

RIGHT VALVE

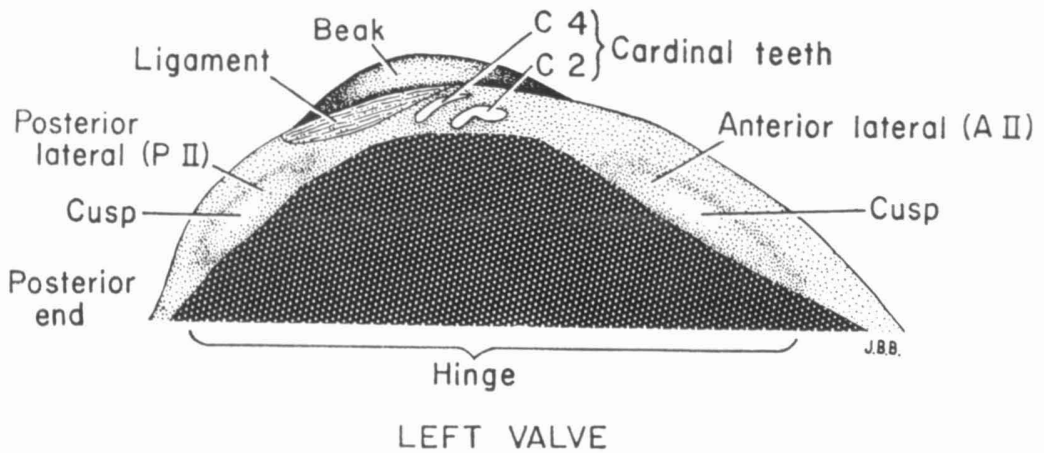

FIG. 2. Hinge teeth terminology. 
or nearly always, have been the typical form with the tubercular beaks and moderately heavy striae. But the specimens found in a lake that is filling up with marl, or other soft material, tend to be more inflated (perhaps to keep them from sinking into the bottom) and have less prominent striae; their beaks, although high and swollen, are closer in appearance to those found in other species.

\section{GEOGRAPHIC DISTRIBUTION}

The distribution of the North American sphaeriids has not been fully studied. In Canada, aside from the older settled parts of the Province of Ontario, relatively little collecting has been done; even in Ontario, only a few counties have been collected thoroughly. D. S. Rawson has collected mollusks in the course of fisheries investigations in Saskatchewan, including Lake Athabaska, and also in Great Slave Lake in the Northwest Territories. Throughout the rest of the country the collecting has been very spotty. There are only a few records from Newfoundland, New Brunswick, Quebec, Manitoba, and Alberta. Similar gaps in collecting are also found in large portions of the United State. No doubt there are in museums and private collections many unidentified sphaeriid specimens from parts of North America from which, as yet, we have no printed records. If these specimens could be studied and the species represented were published, our knowledge of the geographic distribution of these little clams could be considerably increased.

The Sphaeriidae, as presently understood by the author, are represented in North America by 35 species, 12 of which belong to the genus Sphaerium, 22 to Pisidium, and one to Eupera. These species are listed below. 


Sphaerium
S. corneum (Linné) ${ }^{1}$
S. fabale Prime
S. lacustre (Müller)1,3
S. nitidum Clessin ${ }^{1}$
S. occidentale Prime
S. partumeium (Say)
S. patella (Gould)
S. rhomboideum (Say)
S. securis Prime
S. striatinum (Lamarck)4
S. sulcatum (Lamarck)
S. transversum (Say) ${ }^{1}$
Eupera ${ }^{5}$
E. singleyi Pilsbry

\author{
Pisidium \\ $P$. adamsi Prime \\ $P$. aequilaterale Prime \\ $P$. amnicum (Müller)1,2 \\ P. casertanum (Poli) 1,2,3,4 \\ P. compressum Prime \\ $P$. conventus Clessin 1 \\ P. cruciatum Sterki \\ P. dubium (Say) \\ $P$. fallax Sterki \\ $P$. ferrugineum Prime ${ }^{1}$ \\ $P$. henslowanum (Sheppard) 1 \\ P. idahoense Roper \\ $P$. insigne Gabb \\ P. lilljeborgi Clessin1 \\ $P$. milium Held1 \\ P. nitidum Jenyns 1,2 \\ $P$. obtusale Pfeiffer ${ }^{1}$ \\ $P$. punctiferum Guppy1 \\ P. subtruncatum Malm 1 \\ P. ultramontanum Prime \\ $P$. variabile Prime \\ P. walkeri Sterki
}

Nineteen of the species listed are confined to the North American continent, whereas 15 are found in both North America and Eurasia. The limited geographic distribution of Sphaerium corneum, Pisidium amnicum, and $P$. henslowanum in North America indicates that they may have been introduced from Europe, probably since the coming of the white man. Sphaerium transversum, on the other hand, appears to have been introduced to England from North America, perhaps during the first half of the 19 th century.

Most of the named forms of Pisidium casertanum, $P$. conventus, $P$. lilljeborgi, $P$. milium, $P$. nitidum and P. subtruncatum, as well as Sphaerium lacustre and $S$. nitidum found in North America are also found in Eurasia. However, the following forms are peculiar to North America, or are but rarely found in Eurasia: $P$. ferrugineum, $P$. ferrugineum form medianum,

\footnotetext{
1 Found also in Eurasia.

2 Known from Africa.

3 Known from Australasia.

4 Known from Central and/or South America.

s Outside of North America the genus is reported to occur in the West Indies, Central and South America, and in Africa. The range of the species $E$. singleyi (under the name of Byssanodonta singleyi) is given as northern Florida, Georgia, west into Texas, and south into México (Clench and Turner, 1956:218).
} 
P. ferrugineum form costatum, P. lilljeborgi form cristatum, P. nitidum form pauperculum, $P$. nitidum form contortum, $P$. obtusale form rotundatum, and $P$. obtusale form ventricosum. The only North American species not found in Eurasia that appears to be related to a Eurasian species is $S$. rhomboideum, which belongs to the $S$. corneum group.

Some species show a distributional pattern that appears to be correlated with general climatic conditions, while others appear to be influenced more by local environmental factors. I have found that $S$. partumeium thrives in the United States, but reaches only the southern border of Canada. $P$. idahoense extends from Great Bear Lake in the north to the Great Lakes in the south, except in mountainous areas where its southward extension is greater. Temperature seems to be the influencing factor here. This also applies to $P$. conventus, which is found only in mountainous areas, or in deep water when as far south as the Great Lakes. The influence of local environmental conditions shows up in the case of $P$. obtusale. 'The form rotundatum is found most frequently in the shallow water of ponds and lagoons, among grass and leaves. The form ventricosum thrives in small or large lakes and in rivers.

A number of species, such as Pisidium compressum, $P$. nitidum, $P$. obtusale, and Sphaerium striatinum, are known to occur in México also.

Some species, e.g., P. casertanum, are scattered over much of the earth's surface, but $S$. patella is limited to the northwestern United States. $P$. ultramontanum is also limited to a small part of this area, and apparently has survived in it or in contiguous areas since at least early Pliocene times. It is quite unlike other American species, but may be closely related to $P$. chankense Shadin from Lake Khanka, Manchuria-Primorye.

More detailed data on distribution in North America and some available indications on occurrence elsewhere are given with each species.

\section{GEOLOGIC DISTRIBUTION}

Very little information is available on the geologic range of the Recent North American Sphaeriidae. Most of what is reliably known is available in publications by Herrington and Taylor (1958), Taylor (1957, 1960a,b), and Hibbard and Taylor (1960), dealing mainly with the High Plains region (southwest Kansas and northwest Oklahoma) and also the northwestern U. S. A. Additional unpublished information was also provided by Taylor.

Many or most of the Recent American species of Sphaeriidae probably have some antiquity. The earliest record for Pisidium casertanum, $P$. nitidum, and $P$. ultramontanum are from the Early Pliocene; for $P$. com- 
pressum, the Middle Pliocene; and for $P$. henslowanum form supinum, $P$. punctiferum, and Sphaerium striatinum, the Late Pliocene. S. lacustre form rykholti, S. partumeium, S. sulcatum, and S. transversum are known from the Early Pleistocene; $P$. obtusale from the Middle Pleistocene; and $P$. ferrugineum, $P$. lilljeborgi, $P$. subtruncatum, $P$. walkeri, and $S$. occidentale from the Late Pliocene.

Further details are given in the sections dealing with the respective species.

\section{KEY TO THE NORTH AMERICAN SPHAERIIDAE (Genera Sphaerium and Pisidium ${ }^{6}$}

1a. Beaks anterior, or if subcentral, on the anterior side of center (Sphaerium) ... 2

lb. Beaks posterior or, if subcentral, on the posterior side of center (Pisidium) .... 16

2a. Shell sculptured with coarse striae ( 8 or less striae per $\mathrm{mm}$. in the middle of

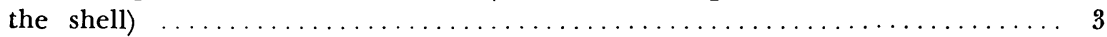

2b. Shell sculptured with fine striae (12 or more striae per $\mathrm{mm}$. in the middle of

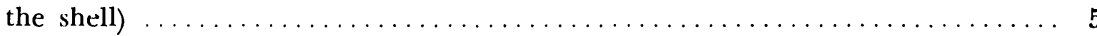

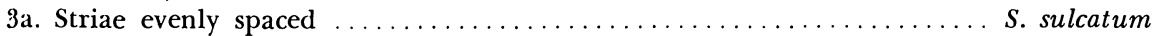

3b. Striae not evenly spaced $\ldots \ldots \ldots \ldots \ldots \ldots \ldots \ldots \ldots \ldots \ldots \ldots \ldots \ldots \ldots \ldots \ldots$

4a. Surface even, except for rest marks and striae; shell inflated; striae not weaker in region of the beaks

S. striatinum

4b. Surface uneven; shell compressed; striae weaker in region of the beaks $\ldots . S$. fabale

5a. Shell large, more than $8 \mathrm{~mm}$. long $\ldots \ldots \ldots \ldots \ldots \ldots \ldots \ldots \ldots \ldots \ldots \ldots$

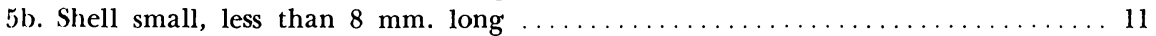

6a. Beaks prominent, distinctly raised above the dorsal margin $\ldots \ldots \ldots \ldots \ldots \ldots \ldots$

6b. Beaks not prominent, only very slightly raised above the dorsal margin $\ldots \ldots \ldots .9$

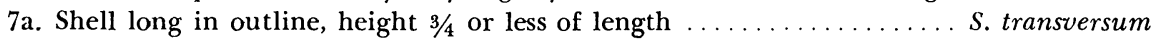

7b. Shell higher in outline, height $7 / 8$ or more of length $\ldots \ldots \ldots \ldots \ldots \ldots \ldots \ldots$

8a. Dorsal margin rather straight; posterior end more or less at right angles to the dorsal margin; striae very fine $\ldots \ldots \ldots \ldots \ldots \ldots \ldots \ldots \ldots \ldots \ldots$. partumeium

8b. Dorsal margin more rounded; posterior end at a greater angle to the dorsal margin; striae coarser

S. lacustre

9a. Shell more or less rectangular in outline ............... rhomboideum

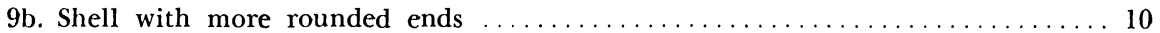

10a. Ends of shell rounded in outline $\ldots \ldots \ldots \ldots \ldots \ldots \ldots \ldots \ldots \ldots \ldots \ldots \ldots \ldots \ldots \ldots$

10b. Ends of shell distinctly tapering toward the beaks $\ldots \ldots \ldots \ldots \ldots \ldots \ldots$. patella

lla. Posterior end nearly at right angles with dorsal margin $\ldots \ldots \ldots \ldots \ldots \ldots \ldots$

11b. Posterior end and dorsal margin rounded or forming an obtuse angle $\ldots \ldots \ldots 13$

12a. Anterior ventral margin of shell slopes sharply upward; surface dull; striae coarser

S. securis

12b. Anterior ventral margin of shell slopes upward, but only slightly; surface glossy; striae finer

S. partumeium

13a. Striae maintain their spacing and height in the region of the beaks ...S. nitidum

13b. Striae fade out in region of beaks $\ldots \ldots \ldots \ldots \ldots \ldots \ldots \ldots \ldots \ldots$

6 Eupera not included. 
14a. Beaks prominent, distinctly raised above the dorsal margin $\ldots \ldots \ldots \ldots \ldots \ldots 15$

14b. Beaks not prominent, only slightly raised above the dorsal margin ..... S. corneum

15a. Anterior and posterior ends of shell round; beaks not swollen ...... S. occidentale

15b. Posterior end of shell truncate; beaks swollen $\ldots \ldots \ldots \ldots \ldots \ldots \ldots$. lacustre

16a. Shell large, adults $6 \mathrm{~mm}$. or more long $\ldots \ldots \ldots \ldots \ldots \ldots \ldots \ldots \ldots \ldots \ldots$

16b. Shell medium or small, adults less than $6 \mathrm{~mm}$. long $\ldots \ldots \ldots \ldots \ldots \ldots \ldots \ldots$

17a. Striae coarser (10 or less per mm.); cusp of P I distal of center $\ldots \ldots \ldots \ldots \ldots 18$

17b. Striae finer $(15$ or more per $\mathrm{mm}$.); cusp of $\mathrm{P}$ I distal $\ldots \ldots \ldots \ldots \ldots \ldots \ldots \ldots$

18a. Striae fade out in region of beaks; cardinals nearer posterior cusps; cusp of A II distal or on distal side of center $\ldots \ldots \ldots \ldots \ldots \ldots \ldots \ldots \ldots \ldots \ldots \ldots$. dubium

18b. Striae do not fade out in region of beaks; cardinals near anterior cusps; cusp

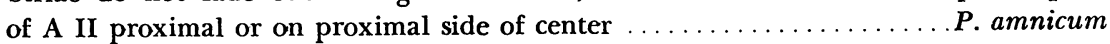

19a. Shell long in outline, height less than 90 per cent of length; surface dull; cusp

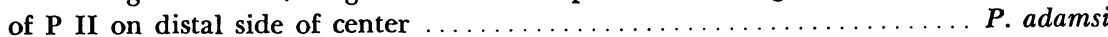

19b. Shell higher in outline, height 90 per cent of length; surface glossy; cusp of P II central or on proximal side of center $\ldots \ldots \ldots \ldots \ldots \ldots \ldots \ldots \ldots \ldots \ldots$ idahoense

20a. Anterior cusp of left valve twisted toward the interior, and the corresponding sulcus in the right valve twisted correspondingly $\ldots \ldots \ldots \ldots \ldots \ldots \ldots \ldots$ fallax

20b. Anterior cusp of left valve not twisted, but parallel to the dorsal margin...... 21

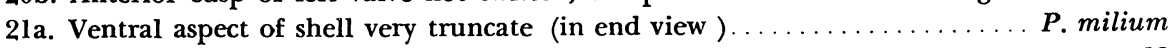

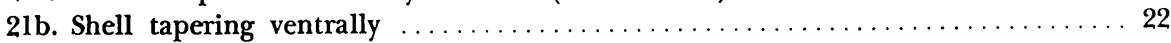

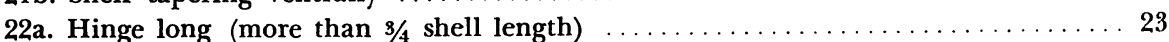

22b. Hinge short (less than $\mathbf{3} / \mathbf{4}$ shell length) $\ldots \ldots \ldots \ldots \ldots \ldots \ldots \ldots \ldots \ldots \ldots \ldots \ldots$

23a. Anterior end terminating in a long blunt point $\ldots \ldots \ldots \ldots \ldots \ldots$. insigne

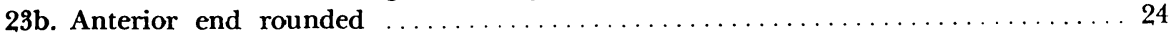

24a. Shell with heavy ridges which usually go beyond the beaks; California and

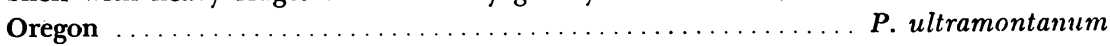

24b. Shell without heavy ridges or, if present, only on the beaks $\ldots \ldots \ldots \ldots \ldots 25$

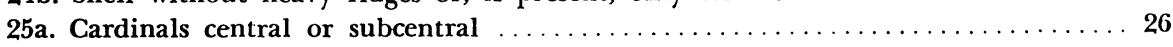

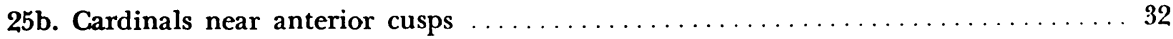

26a. Shell usually shaped like a parallelogram, i.e., anterior and posterior ends sloped at the same angle; found only in cold waters $\ldots \ldots \ldots \ldots \ldots \ldots \ldots$ conventus

26b. Anterior and posterior ends sloped at different angles, not parallel . . . . . 27

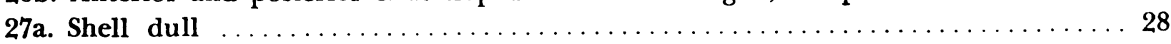

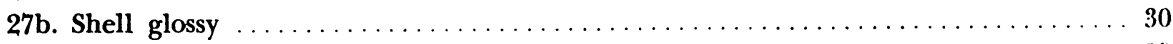

28a. Shell with ridges on the beaks $\ldots \ldots \ldots \ldots \ldots \ldots \ldots \ldots \ldots \ldots \ldots \ldots \ldots \ldots \ldots 29$

28b. Shell without ridges on the beaks $\ldots \ldots \ldots \ldots \ldots \ldots \ldots \ldots \ldots \ldots$ p punctiferum

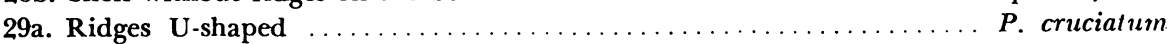

29b. Ridges straight or slightly curved, but not U-shaped . . . . . . . P. compressum

30a. Beaks prominent; moderately striate (less than 30 striae per $\mathrm{mm}$.) ........ 31

30b. Beaks not prominent; finely striate (more than 30 striae per mm.) and frequently with several coarse striae at outer edge of embryonic shell ......... nitidum

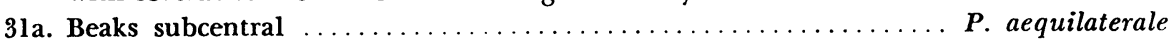

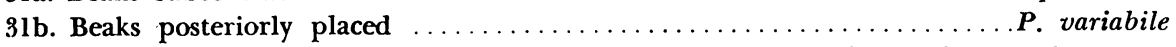

32a. Cusp of A II shaped like a toothpick, i.e., with nearly vertical and parallel

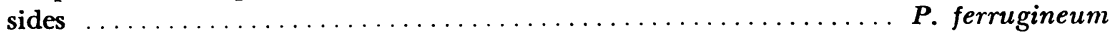

32b. Cusp of A II with steeply inclined sides, but not toothpicklike . . . P. casertanum

33a. Cusp of P II central or on proximal side of center $\ldots \ldots \ldots \ldots \ldots \ldots \ldots \ldots \ldots$

33b. Cusp of P II distal or on distal side of center $\ldots \ldots \ldots \ldots \ldots \ldots \ldots \ldots \ldots \ldots$ 
34a. Surface glossy; finely striate (more than 30 striae per mm.) ............ 35 34b. Surface dull; moderately striate (less than 30 striae per $\mathrm{mm}$.) ....... P. walkeri 35a. Anterior (proximal) end of posterior sulcus in right valve closed ..... P. obtusale 35b. Anterior (proximal) end of posterior sulcus in right valve not closed

P. subtruncatum 36a. Anterior end joining dorsal margin at an angle $\ldots \ldots \ldots \ldots \ldots \ldots$. lilljeborgi $36 \mathrm{~b}$. Anterior end curves gently into the dorsal margin $\ldots \ldots \ldots \ldots \ldots \ldots \ldots \ldots 37$

37a. Cusp of P II central or on distal side of center; beaks never ridged ......... 38 37b. Cusp of P II distal; beaks usually ridged ................ henslowanum 38a. Dorsal margin almost straight or only slightly curved $\ldots \ldots \ldots \ldots . .$. casertanum

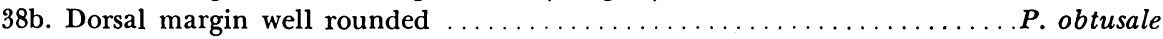

\section{SYSTEMATIC ACCOUNT OF SPECIES ?}

GENUS SPHAERIUM SCOPOLI, 1777

Type: Tellina cornea Linné, 1758

\section{Sphaerium corneum (Linné)}

(Pl. II, Fig. 2)

1758, Tellina cornea Linné.

Measurements8.-UMMZ 200802. Rice Lake, Peterborough Co., Ontario. Length: 8.6, 6.5, 4.5, 3.1. Height: 7.1, 5.5, 3.7, 2.4. Diameter: 5.2, 3.6, 2.4, 1.3. Some European specimens are much larger; one valve from Lake Etaillères, Jura, Neuchâtellois: L: 13.5; H: 11.0.

Diagnostic Charactrrs 9 .-Shell rather small to medium size, walls thin, considerably inflated, resembling an elongated sphere; beaks very low and broad, about central; striae fine, evenly spaced, smaller on the beaks and becoming very fine or fading out; periostracum moderately glossy; dorsal margin of moderate length, gently curved; ventral margin fairly long, a little more openly curved than the dorsal; anterior end rounded, joining the dorsal margin without an angle and the ventral margin with either a much rounded angle or more steeply rounded angle; posterior end rounded or roundly truncate, usually joining the margins imperceptibly, but sometimes extending downward (in which case the ventral margin is somewhat flattened), and forming a blunt angle with the ventral margin; hinge rather long, evenly curved, of fairly even width, i.e., it widens very little at the cusps; hinge-plate rather long; in the right valve and at anterior end of the left valve in wellinflated specimens there is a slight dip as the cusps are approached; cusp of A II rises rather steeply on each side, cusps of P II resemble an inclined plane (but in well inflated specimens the sides are steep); the cusps are all distal or on the distal side of center. Some laterals appear longer either in front or behind the cusps. The cardinals are slim, clear-cut and distinct, and near the anterior cusps; C 3 is parallel with the hinge-plate and is a rounded curve with the posterior end enlarged and somewhat bifurcate. Sometimes the anterior end is lengthened by a straightening or slight outward curve. C 2 is

\footnotetext{
; The species are in alphabetical order.

8 Unless otherwise stated, 13 specimens were selected to represent size range, then arranged in a graded series. From these the first, fifth, ninth, and thirteenth were chosen to measure and are recorded under each species. Measurements are in millimeters.

${ }^{9}$ In this section I have usually had in mind the average of the respective species.
} 
parallel with the hinge-plate, varying much in shape, straight to considerably curved, or has posterior end extending more toward inner edge of hinge-plate, and/or anterior end has an extension parallel with the hinge-plate. C 4 is straight or somewhat curved, about the length of $\mathrm{C} 2$ or a little longer, and begins outside $\mathrm{C} 2$, directed at or inside cusp of P II.

Comparisons. $-S$. nitidum is a member of the same group as $S$. corneum, and looks like a small form of that species with a shorter hinge. However, the striae of $S$. nitidum go right up over the beaks, the hinge is short, $\mathrm{C} 2$ is nearly straight, and it lives in colder water. Odhner (1939: 79) stated: "The two species are different also in the soft part, e.g. the proportion of gills and shape of nephridium, as I have shown in 1929."

There is also considerable external resemblance between $S$. corneum and $S$. occidentale. However, $S$. corneum is larger, the dorsal margin more curved, the height in front of and behind the beaks more unequal, the ends less vertical, the hinge less uniformly curved, and most of the cusps are distal or on the distal side of center. In $S$. occidentale none of the cusps are distal but all are proximal, central, or on the distal side of center. Also, $S$. occidentale is a swamp or pond species.

The shell walls of $S$. corneum are much the same as in $S$. rhomboideum, and the nepionic young show a close relationship. However, $S$. rhomboideum is much larger, the ventral margin less curved, and the ends show a more pronounced slope. The height of $S$. rhomboideum in front and behind the beaks is more nearly equal so that the outline of the shell is more rectangular. No difference in the hinge characters can be detected.

Some $S$. striatinum with faint striae have some resemblance to $S$. corneum, but they are longer than most $S$. corneum, the shell walls are heavier and not so inflated, the end slopes more pronounced, and the width of the hinge at the anterior cusps of the right valve is much greater.

Habitat.-It has not spread far enough in North America for our statements to be of much value, but so far has been found in large rivers and lakes (including the Great Lakes). It has been collected from fine, soft sand near the shore of Rice Lake and the Bay of Quinte.

Geographic Distribution.10_CAnada: Ontario (St. Lawrence River, Lake Ontario, Bay of Quinte, Rice Lake, and Lake Erie). united states: New York (Lake Champlain) and Ohio (Lake Erie). It appears to be an introduced species. Furasia.

\section{Sphaerium fabale Prime \\ (Pl. II, Fig. 3)}

1851, Cyclas fabalis Prime.

1865, Spaerium fabalis Prime.

1916 $b$, Sphaerium fabale Sterki.

Measuremfnts.-UMMZ 200803. Salmon River, Richmond Twp., Lennox and Addington Co., Ontario. Length: 11.25, 10.0, 6.2, 4.6. Height: 9.0, 8.0, 5.0, 3.8. Diameter: 5.9, $4.9,2.9,1.6$.

Diagnostic Characters.-Shell of medium size, little inflated, rather high in outline; beaks toward anterior end, very low, narrow on top; striae faint at beaks, becoming gradually more prominent and coarser as the shell grows (before half-grown the striae are

10 The statements about geographic distribution for North America are based on specimens I have personally examined, unless specifically indicated to the contrary. 
coarse and irregular, as in many specimens of $S$. striatinum); periostracum dull; dorsal margin moderately long and rather steeply rounded, a slight bend immediately in front of the beaks; ventral margin of moderate length, rounded or somewhat flattened; anterior end beginning immediately in front of the beaks, a gently curved slope, descending rather low and joining the ventral margin with or without a rounded angle, and joining the dorsal margin without an angle; posterior end a rounded slope joining the ventral margin low and without an angle, and also joining the dorsal margin without an angle; hinge almost full length of the shell, gently rounded with a distinct bend between the cardinals and the anterior laterals, widening only slightly at the laterals and dipping slightly at the proximal end of the anterior laterals; hinge-plate very long, moderately narrow, laterals moderately short, but distinct; cusps rather blunt on top, only those of A I and A II rising with any prominence (in the rest the laterals and cusps are an inclined plane); cusp of A I and A II distal or on distal side of center, the other cusps are all distal; cardinals near anterior cusps, small and not very distinct; anterior end of C 3 near outside of hinge-plate, short and much curved, posterior end enlarged so the cardinal is diagonal to hinge-plate; C 2 back from inner edge of hinge-plate, short, low, blunt, shaped like a peg or an inverted letter D; C 4 longer than C 2, slim, beginning outside center of C 2, curving slightly, or straight, and directed well inside cusp of P II.

Comparisons. $-S$. patella of small diameter; resembles $S$. fabale closely in shape; the two appear to belong to the same group. However, $S$. patella has very fine striae over the whole shell, and a gloss. Most of the shell of $S$. fabale has rather heavy, uneven striae or growth marks, and the periostracum is dull.

Therc are some fairly high $S$. striatinum of small diameter that may be confused with $S$. fabale. The shape and hinge characters are much the same, but $S$. fabale has only fine striac on the beaks, and never has heavily striated beaks.

НАвттат.-Creeks and small rivers. I have found it only in coarse gravel or in gravelly sand in cracks on a flat limestone bottom.

GEographic Distribution.-CANAda: reported from only five counties in Ontario, all within 125 miles of Toronto. United states: New York, New Jersey, Maryland, Pennsylvania, Virginia (Prime), West Virginia, Tennessee, Albama, Georgia (Prime), Ohio, Michigan, and Illinois.

\section{Sphaerium lacustre (Müller)}

(P1. II, Fig. 1)

1774, Tellina lacustris Müller.

1844, Cyclas ryckholti Normand.

1851, Cyclas rosacea Prime.

1851, Cyclas jayensis Prime.

1865, Sphaerium lenticula Prime.
1892, Spaerium raymondi Cooper. 1909c, Musculium winkleyi Sterki. 1910c, Musculium pusillum Sterki. 1912a, Musculium Qeclive Sterki.

Measurements.-UMMZ 199636. Hay Bay, Adolphustown Twp., Lennox and Addington Co., Ontario. Selected specimens of form jayense Prime. Length: 9.0, 7.0, 5.5. Height: 7.2. 5.7, 4.5. Diameter: 5.4, 4.5, 3.0. UMMZ 199599. Sunnyside, Lake Ontario, Toronto, Ontario. Collected by Latchford. L: 14.0; H: 11.5; D: 8.2. UMMZ 196266. Lake Sammamish, King Co., Washington. Form ryckholti. Collected by W. J. Eyerdam. L: 7.5; H: 7.0; D: 5.0 .

Diagnostic Characters.-Shell small to medium size, walls thin, little to considerably inflated, anterior end not so high as the posterior; beaks somewhat toward anterior end, 
swollen and full, varying in height, usually capped, but not always, caps vary from large to small; striae moderately fine to fine, uneven (not as smooth as in S. partumeium); periostracum a slightly dulled gloss; dorsal margin long, slightly to considerably curved; ventral margin varying from considerably curved to a little flattened; anterior end rounded or with a rounded slope (in which case it joins the ventral margin with a slight angle), joining dorsal margin with a small angle; posterior end almost straight, joining the dorsal margin with a sharp or slightly rounded angle and the ventral margin with a slightly rounded angle. The ends are seldom parallel, but slope up toward the dorsal margin. Sometimes the posterior end has a much longer slope than the anterior, in which case the lower part extends farther out. Hinge very long, slightly to considerably curved, usually with a bend behind the cardinals; hinge-plate fairly long and very narrow, sometimes almost absent and then the laterals seem to be attached to the walls and the cardinals are partly suspended over space; laterals slim but distinct; there is a slight dip at the proximal end of the anterior ones, and A I and A II appear to swing under the hinge-plate at their proximal ends; the posterior laterals form a gentle inclined plane; all cusps are distal, only those of the anterior laterals have any degree of prominence; cardinals weak, closer to cusps of anterior laterals; C 3 short, parallel to hinge-plate, more or less roundly curved, posterior end enlarged and usually bifurcate; C 2 short and slim; C 4 also short and slim, straight, roughly parallel with $\mathbf{C} 2$, directed at or outside cusp of P II. The hinge-plate is so narrow that the cardinals are delicate and vary greatly in shape and direction.

The apparently ecological form, S. lacustre form ryckholti (Normand), has higher beaks and a pronouncedly curved hinge, the dorsal margin proportionately much shorter, the ventral margin long and greatly curved; the ends have a more rounded slope, and C 2 and $\mathrm{C} 4$ are directed outside both the posterior and anterior cusps. In some western specimens of ryckholti the beaks attain a proportionately enormous size.

The ecological form $S$. lacustre form jayense Prime has a more nearly straight dorsal margin with ends more truncate and the ventral margin is but little curved. This form is roughly rectangular except that the dorsal margin is shorter than the ventral, giving a slope to the ends.

Comparisons.-Some shells of $S$. lacustre have something of the shape of $S$. partumeium, i.e., a rather straight dorsal margin at right angles to the posterior end. However, the anterior end of $S$. lacustre is less rounded and joins the ventral margin lower down, the ventral margin is less curved, the striae are coarser and less even, and the shell has less gloss. In $S$. partumeium the striae are fine and the surface smooth, and both the anterior end and the ventral margin are more rounded.

Some $S$. lacustre have a fairly straight dorsal margin with the posterior end placed at right angles to it as in S. securis. But in S. securis the striae are more uniform and heavier, and the anterior end of the ventral margin swings much higher, making the shell much less high at the anterior than at the posterior end. When $S$. securis and $S$. lacustre live in the same habitat the periostracum of $S$. securis has less or no gloss.

Habitat.-Most plentiful in small lakes and ponds, but also found in large lakes, rivers, and creeks. It appears to have preference for a muddy bottom. I have collected the $S$. lacustre form ryckholti from ponds and bog-ponds, and S. lacustre form jayense from the mud of Rice Lake, Peterborough Co., Ontario, and in Hay Bay, Lennox and Adding. ton Co., Ontario. In the latter place most specimens were obtained from black ooze a quarter to a half mile from shore, at a depth of $6-8$ meters.

Geographic Distribution.-Canada: Cape Breton Island, Quebec, Ontario, Manitoba, Saskatchewan, British Columbia, and Northwest Territories (Great Slave Lake). UNITED 
states: Maine, New Hampshire, Massachusetts, Rhode Island, New York, New Jersey, Pennsylvania, Delaware, Virginia, Tennessee, Alabama, Georgia, Florida, Ohio, Michigan, Indiana, Wisconsin (Baker 1928a: 359), Illinois, Minnesota, N. Dakota, S. Dakota, Nebraska, Iowa, Louisiana, Montana, Wyoming, Washington, Oregon, Idaho, Colorado, California. FAR EAST AND PACIFIC AREA: Japan, Hawaii. EUROPE.

S. lacustre form ryckholti has been found as a fossil in Early and Middle Pliocene deposits (Dixon, Cudahy, and Berends faunas) of Kansas and Oklahoma, U.S.A.

\section{Sphaerium nitidum Clessin \\ (P1. I, Fig. 6)}

1876, Sphaerium nitidum Clessin, in Westerlund. 1901, Sphaerium walkeri Sterki.

1886, Sphaerium uintaense Call.

$1916 b$, Sphaerium tenue walkeri Sterki.

(The reasons for dropping the name tenue Prime are given by Herrington, 1958)

Measurements.-UMMZ 200407. False Pass, Unimak Id., Aleutian Islands, Alaska. Collected by W. J. Eyerdam. Length: 6.1, 5.5, 3.5, 2.4. Height: 5.1, 4.5, 3.0, 2.0. Diameter: $3.8,3.2,1.8,0.8$.

Diagnostic Characters.-Shell small, considerably inflated, walls very thin, somewhat spherical in outline; beaks about central, low; striae moderately fine, uniformly spaced and maintaining their size right up over the beaks; periostracum a dull gloss; dorsal margin rounded, rather short; ventral margin much longer than dorsal and not so steeply rounded; anterior end round, joining ventral margin with a slight angle only slightly below median line and joining dorsal margin at anterior cusps with or without a slight angle; posterior end rounded, but descending low where it joins ventral margin far down in a distinct angle; joins dorsal margin with or without a slight angle; hinge short, narrow, and only slightly widening at cusps; cusps all distal, moderately sharp on top; cardinals near anterior cusps; hinge-plate very narrow with all the cardinals slim and rather faint; C 3 parallel with hinge-plate, almost straight and only slightly enlarged at posterior end; C. 2 straight, parallel with hinge-plate and close to its inner edge; C 4 beginning outside C. 2, but not quite parallel to it, slightly curved and directed slightly inside cusps of P II. $S$. nitidum has roughly the appearance of a small, well-inflated $S$. corneum.

Comparisons.-See $S$. corneum.

Habitat.-Requires cold water, hence found only in deep water, at considerable altitudes, or quite far north.

Geograpiic Distribution.-CANAda: Newfoundland, Quebec, Ontario (Lakes Ontario, Superior, and Nipigon), Saskatchewan (northern lakes), Alberta (Amethyst Lake), British Columbia, and Northwest Territories (to Great Bear Lake). United states: Maine (Androscoggin River), New York (Lake Champlain and Cayuga Lake), Michigan (Lake Michigan), Washington, Idaho, Utah, and Alaska (Aleutian Islands). EURAsIA.

\section{Sphaerium occidentale Prime}

(Pl. I, Fig. 4)

1853, Cyclas ovalis Prime (Preoc.)

1860a, Sphaerium occidentale Primc.

1865, Sphaerium occidentale Prime.

Measurements.-UMMZ 200804. Creek one-half mile SE Thomasburg, Hastings Co., Ontario. Length: 7.0, 5.9, 4.5, 2.3. Height: 6.0, 4.9, 3.8, 1.8. Diameter: 4.1, 3.2, 2.2, 1.0 . 
Diagnostic Characters. - Shell small, rounded, a little longer than high, moderately inflated, "rest periods" prominent, walls of shell thin, about as high in front of beaks as behind; beaks moderately narrow and not very high, about central; striae fairly fine, becoming finer as beaks are approached; periostracum dull or having a dull gloss; dorsal margin moderately long, very gently curved, usually joining ends with the slightest angles; ventral margin long, gently curved, joining ends without an angle; anterior end a broad curve, posterior end sometimes a little more flatly curved than the anterior; hinge very long (almost full length of shell); hinge-plate long, slim (slightly heavier in ditch and pond forms), very gently, evenly curved and of uniform width; laterals fairly slim, those of the left valve and the inner ones of the right valve moderately long; cusps of left valve and inner cusps of right valve sharp or only slightly blunted on top; cusp of A I cen. tral or on proximal side of center, of P I and P II central or on proximal or distal side of center, of A II proximal to central; A III and P III are very short with cusps at distal end; cardinals near anterior cusps, slim but distinct; C 3 moderately long, somewhat curved or straight, at outside of hinge-plate, somewhat enlarged at posterior end; C 2 straight (top sometimes curved slightly by bending outward), in heavier specimens curved or bent at its posterior end, parallel with the hinge-plate, or posterior end slightly farther from its inner edge; C 4 less distinct, straight or with the slightest curve, beginning at the outside of the posterior end of $\mathrm{C} 2$ and angling gently across hinge-plate (C 2 and C 4 not parallel to each other). The proximal end of all laterals remain on top of the hinge-plate. In many specimens A II extends along the hinge-plate in front and behind the cusp, making the lateral appear very long. There is a ridge on the inside of the shell about midway between the ends, and reaching from near the beaks to the ventral edge of the shell. This ridge has not been found in any other species. It was also a distinctive feature in specimens of the Sangamon Interglaciation. The dorsal margin of the nepionic young is almost straight, and the ends are well rounded.

Comparisons.-There is some resemblance between sphaerium occidentale and $S$. partumeium. They are both fragile and are sometimes found together. Both have a rounded anterior end and rounded ventral margin. However, $S$. occidentale has a rounded; not truncated, posterior end; the height of the shell is pretty much the same in front of the beaks as behind; the hinge-plate is of even width, evenly curved, and lacks the bend behind the cardinals; the dorsal margin is curved about as much as the ventral; the shell is almost free from angles; the laterals are different, with the cusps about central.

Occassionally a swamp form of Pisidium casertanum is mistaken for very young of Sphaerium occidentale, but the beaks of the pisidia are more posterior (see also $S$. corneum).

HabrTat.-Stillwaters of swamps, ditches, and ponds; among grass and leaves. This species has a preference for, or requires, a habitat that dries up for part of the year.

Grographic Distribution.-Canada: New Brunswick, Quebec, Ontario (north to Thunder Bay District, Lake Superior). united states: Vermont, Massachusetts, Connecticut, New York, New Jersey, Pennsylvania, Delaware, Virginia, S. Carolina, Tennessee, Alabama, Georgia, Ohio, Michigan, Indiana, Wisconsin, Illinois, Montana, Wyoming, Washington, Oregon, Idaho, Utah, and Colorado.

Fossil specimens of $S$. occidentale have been identified in Late Pleistocenc deposits of Sangamon age (Jinglebob fauna) in Meade Co., Kansas, U.S.A. 


\title{
Sphaerium partumeium (Say)
}

\author{
(Pl. I, Fig. 5)
}

1822, Cyclas partumeia Say.

1841, Cyclas elevata Haldeman.

1848, Cyclas truncata Linsley, in Gould.

1865, Sphaerium contractum Prime. 1902b, Calyculina hodgsoni Sterki. 1902b, Calyculina ferrissi Sterki.

1913, Musculium orbiculare Sterki.

Measurements.-UMMZ 200807. Creek northwest of Newburgh, Camden Twp., Lennox and Addington Co., Ontario. Length: 7.0, 5.5, 3.8, 2.6. Height: 6.1, 4.6, 3.3, 2.2. Diameter: $3.5,3.0,1.9,1.4$. Specimens from the United States attain a much greater size than any found in Canada. One specimen from Massachusetts, in Prime's collection at the Museum of Comparative Zoology, Cambridge, Massachusetts (MCZ 19480), measured: L: $12.5 ; \mathrm{H}: 10.5 ; \mathrm{D}: 8.0$. In the deep south there is a tendency for the walls to be thicker, the shell larger, and the dorsal margin more curved. UMMZ 199649, Parson's Slough, Trinity River, Kaufman Co., Texas, measured: L: 13.5; H: 11.5; D: 9.0 .

Diagnostic Characters.-Shell rather small to medium size, somewhat short in outline, walls thin; beaks about central or slightly anterior, low and but little swollen; striae fine and evenly spaced; periostracum glossy and smooth; dorsal margin almost straight and about as long as ventral margin; ventral margin well curved; anterior end usually well rounded, but sometimes slightly truncate, joining the dorsal margin with an angle and the ventral margin without an angle (except when slightly truncate; then it has a very slight angle); posterior end truncate, slightly rounded, vertical (i.e., at right angles to the dorsal margin, but at times the end is less steep and the lower part extends out somewhat), joining the dorsal margin with a sharp angle and the ventral margin with a less sharp one; hinge slightly rounded, long, same length as dorsal margin; hinge-plate rather long and very narrow (sometimes causing laterals to appear to be clinging to walls of shell), having a very slight bend behind cardinals; laterals of moderate length (those of left valve and the inner ones of right valve are slim but very distinct; the proximal ends of anterior ones dip slightly; none appear to swing under hinge-plate at proximal end); the very low posterior cusps are at distal end of laterals, which form a gentle inclined plane; anterior cusps rise more distinctly from the dip, and are distal, but sometimes on distal side of center; cardinals much closer to anterior cusps, weak; C 3 short, slightly curved, enlarged a little at posterior end, parallel to hinge-plate which is so narrow that this cardinal usually partly overhangs the valve cavity; $C 2$ short, sometimes little more than a peg, usually with a slight curve at posterior end (sometimes this cardinal is located on proximal end of A II); C 4 very slim, about as long as or a little longer than C 2, directed toward cusp of P II or a little inside.

In the large, heavy specimens from the southern states the shell is heavier than in either those from the northern states or from Canada; the dorsal margin and posterior end of these are more curved and since the hinge is heavier the laterals extend beyond the cusps. This makes the cusps appear less distal and A I and A II show some tendency to swing under the hinge-plate at their proximal end. Most specimens found in Canada are very fragile, some transparent.

Comparisons. $-S$. partumeium and $S$. securis are much the same in size and in position and shape of beaks; in both, the dorsal margins and posterior ends are at right angles. When the periostracum is gone some specimens are hard to place because the anterior end of the ventral margin in $S$. partumeium also tends to swing upwards. However, the striae of $S$. securis are heavier, and the anterior end of the ventral margin swings higher.

Some short $S$. transversum may be confused with $S$. partumeium, but the coarser 
striae, longer shell, and less curved ventral margin of $S$. transversum should serve to distinguish these two species. See also sections under $S$. lacustre and $S$. occidentale.

HaBitat.-Ponds, swamps, small lakes, and slow-moving streams. It has a preference for a muddy bottom, and is fairly common.

Geographic Distribution.-Canada: New Brunswick, Quebec, Ontario (southern part only), Saskatchewan. Unired staTEs: Maine, Vermont, Massachusetts, Rhode Island, Connecticut, New York, New Jersey, Pennsylvania, Delaware, District of Columbia, Virginia, N. Carolina, S. Carolina, Tennessee, Mississippi, Alabama, Georgia, Florida, Ohio, Michigan, Indiana, Wisconsin (Baker, 1928a:354), Illinois, Minnesota, Nebraska, Iowa, Missouri, Kansas, Oklahoma, Louisiana, Texas, Montana, California, and Nevada.

Early Pleistocene fossils of Late Nebraskan age have been found in the Sand Draw and Dixon faunas and in Late Pleistocene strata (Jinglebob fauna) in Kansas, U.S.A.

\section{Sphaerium patella (Gould)}

(P1. II, Fig. 4)

1850, Cyclas patel’a Gould.

1878, Sphaerium primeanum Clessin.

For information about Sphaerium nobile Gould (1855), as used by Sterki, see Herrington $(1950 b)$.

Measurements.--UMMZ 200805, 200806. Selected specimens from Washington Statetwo stations. Length: 14.5, 12.5, 8.2, 5.5. Height: 10.7, 9.0, 6.5, 4.6. Diameter: 8.0, 6.3, 4.0, 2.0.

Diagnostic Characters.-Shell fairly large, moderately to considerably inflated, rather long in outline, walls of medium thickness; beaks slightly anterior, low, enlarged in wellinflated specimens, narrow; striae very fine on and near beaks, becoming somewhat coarser and uneven as growth continues; periostracum somewhat glossy; dorsal margin fairly long, considerably rounded, passing into ends without an angle; ventral margin long and more openly rounded; anterior and posterior ends slope to join ventral margin with a well-rounded angle. The two ends are much the same with the posterior end usually beginning a little higher and somewhat steeper. The hinge is rather long, considerably curved, with a small bend between the cardinals and the anterior laterals caused by the hinge-plate narrowing here and the hinge widening somewhat at the anterior laterals; hinge-plate long, of moderate width, usually with a very slight widening at cardinals and a dip at proximal end of anterior laterals; laterals distinct, short or moderately short, all remaining on top of hinge-plate; cusps of A I, A III, and P III distal, of P I and A II central or on proximal or distal side of center, of P II distal or distal side of center; cardinals near anterior cusps; C 3 at anterior end near outside of hinge-plate, short, and much curved; posterior end considerably enlarged, the whole diagonal to hinge-plate; C 2 back from inner edge of hinge-plate, short, curved; C 4 slightly longer than C 2 , beginning outside posterior end of $\mathrm{C} 2$, straight or very slightly curved and directed well inside cusp of P II.

Comparisons.-See $S$. fabale.

Habitat.-Sloughs, lakes, creeks, and rivers.

Geographic Distribution.-United statrs: Washington, Oregon, Idaho, and California (Modoc Co.). 


\section{Sphaerium rhomboideum (Say)}

(P1. I, Fig. 3)

1822, Cyclas rhomboidea Say.

Measurements.-UMMZ 200808. Marsh Creek, Adolphustown Twp., Lennox and Addington Co., Ontario. Length: 13.1, 8.3, 6.5, 3.6. Height: 10.5, 6.7, 5.6, 3.1. Diameter: $8.5,5.2,3.1,1.6$.

Diagnostic Characters.-Shell moderately large, much inflated, walls thin; beaks central, low and broad, but begin rather narrow; striae fine and regular (very fine on beaks); periostracum glossy; dorsal margin gently curved and moderately long; ventral margin almost straight and very long; anterior end somewhat pointed and rounded joining dorsal and ventral margins without an angle; posterior end somewhat truncate, joining dorsal margin with a slight angle, and ventral margin with a greater angle. These angles vary in different specimens. The ends tend to taper outward as they descend, and the greatest length of the shell is rather low. Hinge long, gently but not evenly curved, bending between the cardinals and the anterior laterals; hinge-plate long, of even width, with considerable dip where the anterior laterals begin and a somewhat lesser dip where the posterior laterals begin; laterals clear-cut, of moderate length but thin; cusps rather steep and mostly sharp on top, those of the left valve high; cusp of A I and A II on distal side of center or rather distal, of P I, P II, A III, and P III distal or somewhat so; cardinals near anterior cusps; C 3 slim, weak, and varies greatly (sometimes a gentle curve; more rarely the anterior end curves outward slightly and then the cardinal assumes the shape of a slim S), with a slight thickening at posterior end, which is sometimes bifurcate; C 2 slim, curved (when anterior end curves outward the cardinal becomes slightly S-shaped; sometimes the posterior end is more steeply hooked); C 4 is longer than C 2 and extends outside of it for about two-thirds of the latter's length and then curves slightly toward the inside of the shell. Most specimens of this species have definite bands of color, the latest growth being lighter than the older part of the shell. The nepionic young are somewhat square in outline with the anterior end not so vertical as the posterior.

\section{Comparisons.-See $S$. corneum.}

Habitat.-Eddies in creeks and rivers; ponds; sheltered places in small lakes. Has a preference for muddy bottom with weeds and algae. The specimens used above for measurements were collected from such a habitat in a limestone region. They were distributed through the algae from top to bottom in water from 12 to 18 inches deep.

Geographic Distribution.-Canada: Ontario (as far north as James Bay). United srates: Maine, Vermont, Massachusetts, Rhode Island, Connecticut, New York, Pennsylvenia, Ohio, Michigan, Minnesota, Iowa, Montana, Idaho. Sterki (1916b: 438) gives, in addition, "Wisconsin ... Manitoba, Alaska, British Columbia (?), Nevada (?)." The Alaskan record is probably based on a confusion by someone with $S$. nitidum, which is plentiful in Alaska and is a smaller member of the same group. 


\section{Sphaerium securis Prime}

(Pl. I, Fig. 2)

1851, Cyclas securis Prime.

1909c, Musculium parvum Sterki. 1853a, Cyclas sphaerica Anthony, in Prime. 1916b, Musculium australe Sterki. 1865, Sphaerium securis Prime.

Measurements.-UMMZ 199715. Moira River, E of Chapman's Corners, Hungerford Twp., Hastings Co., Ontario. Length: 6.3, 5.0, 2.8, 2.1. Height: 5.2, 4.4, 2.2, 1.7. Diameter: $3.9,2.8,1.6,1.1$.

Diagnostic Characters.-Shell small, considerably inflated, much higher at posterior than at anterior end; walls fairly light; beaks subcentral, of moderate height and somewhat swollen (they do not readily blend into the shell, but frequently form a faint ridge extending across the shell toward the lower part of the posterior end; a slighter ridge is also sometimes discernible at the anterior end); striae fairly coarse to moderately fine, distinct and evenly spaced; periostracum dull, sometimes glossy. Those with coarser striae have a duller gloss and frequently live in a habitat that produces an accretion of foreign matter, often rusty brown, on most of the shells. In some waters this accretion is not on all of the shells; in other places (e.g., the Bay of Quinte at Carrying Place, Ontario, where the shells have a high gloss and very fine, distinct striae) it can scarcely be detected. Specimens that show considerable gloss and are free from the coating of foreign matter appear to be on the margin of the customary habitat of this species. The dorsal margin is almost straight to slightly curved, fairly long; ventral margin a little longer than dorsal, well curved, and swinging high at anterior end, resulting in a greater disparity between the height of the anterior and posterior ends, in this species, than in any other Sphaerium; anterior end well rounded, sometimes with a slight slope, and joining the ventral margin without an angle, but frequently having an angle where it joins the dorsal margin; posterior end truncate, at right angles to dorsal margin, but sometimes extending out a little (then not quite vertical), joining dorsal margin with a fairly distinct, rounded angle, and ventral margin with a less distinct angle; hinge almost full length of shell, gently but not evenly curved, a slight bend behind the cardinals; hinge-plate very narrow, but widening a bit as laterals are approached, with a slight dip at the proximal end of interior laterals; laterals of medium length or fairly long, all in an inclined plane, anterior ones a little steeper; cusps but little elevated above laterals and all distal; cardinals subcentral to near anterior cusps, indistinct; C 3 rather short, about straight, posterior end slightly enlarged (enlarged part overhangs interior of shell); C 2 short, straight, and directed at or inside cusp of P II; C 4 short, straight, about parallel with C 2 or directed a little more outward.

The form sphaericum Anthony is usually heavily coated with a rust-colored accretion, inflated, and the dorsal margin is considerably curved.

Comparisons.-See $S$. partumeium.

Habitat.-Ponds, lakes, and rivers. Frequently found in fine sand.

Geographic Distribution.-CANAda: Newfoundland, Nova Scotia, New Brunswick, Quebec, Ontario (southern part only, north and east of Toronto), British Columbia. United states: Maine, Massachusetts, Rhode Island, Connecticut, New York, New Jersey, Pennsylvania, Maryland, Virginia, N. Carolina, S. Carolina (Sterki), Tennessee, Mississippi, Alabama, Florida, Ohio, Michigan, Indiana, Wisconsin, Illinois, Minnesota, Nebraska, Iowa, Arkansas, Louisiana, Texas, Montana, and Washington. 


\section{Sphaerium striatinum (Lamarck)}

(P1. II, Fig. 5)

1818, Cyclas striatina Lamarck.

1829, Cyclas triangularis Say.

1834, Cyclas staminea Conrad.

1841, Cyclas dentata Haldeman.

1851, Cyclas flava Prime.

1851, Cyclas emarginata Prime.

1851, Cyclas acuminata Primc.

1851, Cyclas solidula Prime.

1851, Cyclas modesta Primc.

1851, Cyclas aurea Prime.

1861, Sphaerium vermontanum Prime.
1863, Sphaerium tumidum Baird.

1863, Sphaerium spokani Baird.

1898, Sphaerium lilycashense F. C. Baker.

1903, Sphaerium jalapense Pilsbry.

1906, Sphaerium hendersoni Sterki.

1909a, Sphaerium pilsbryanum Sterki.

1913, Sphaerium acuminatum Sterki.

1913, Sphaerium ohioense Sterki.

1916b, Sphaerium torsum Sterki.

1922b, Sphaerium declive Sterki.

1927, Sphaerium notatum Sterki.

Measurements.-UMMZ 206760. Bridge over Ouse River on highway from Hastings to Keene, Aphodel Twp., Peterborough Co., Ontario. Length: 12.5, 10.1, 7.2, 3.9. Height: $9.6,8.0,5.5,3.1$. Diameter: 7.3, 6.0, 4.0, 2.5. Some creek specimens are larger: UMMZ 200809. Bethany Creek, Bethany, Peterborough Co., Ontario. L: 15.5; H: 12.5. The lake form is relatively higher: UMMZ 206761. Lake Ontario, $1 \mathrm{mi}$. W of Outlet, Athol Twp., Prince Edward Co., Ontario. Shore debris L: 10.0; H: 8.5 .

Diagnostic Characters.-Shell medium to large, moderately inflated, shell wall moderately thin to fairly thick; beaks somewhat toward anterior end, low to prominent; striae irregular; some specimens heavily striated over whole shell, some have heavy striac on beaks, but they almost fade out toward outer part of shell; in some, striae are faint on beaks, but become heavier farther out; in other sets, striae can hardly be seen; periostracum dull (the lake form sometimes attains some gloss); dorsal margin of medium length, roundly and fairly evenly curved; ventral margin long and more openly curved; anterior end roundly curved, joining dorsal margin without an angle and ventral margin with or without a rounded angle; posterior end usually a slope joining margins with or without an angle; hinge fairly long, considerably and unevenly curved, with a slight dip at proximal end of anterior laterals, the inner anterior laterals projecting considerably into interior of shell; hinge-plate fairly long, narrow, a little wider at posterior end; laterals rather short, proximal ends of A I and P I frequently appear to dip under hinge-plate; anterior laterals short, posterior ones moderate in length; cusps of right valve low and blunt on top, central or on distal side of center or even distal; cusps of left valve rather high and blunt, of A II central or on proximal or distal side of center; cardinals near anterior cusps, short but distinct; C 3 almost parallel with hingeplate, more or less curved, somewhat enlarged at posterior end (this end is nearer the inside of the hinge-plate); C 2 short, near inner edge of hinge-plate, a curve or bend with posterior end nearer inner edge of hinge-plate (when the top bends outward it takes on the appearance of a peg); C 4 slim, longer than C 2, begins outside center of C 2 , straight or slightly curved, directed at cusp of P II or inside.

There is a great lack of uniformity in size and outline of the shell; river specimens, which appear to be the typical form, are rather long in outline; lake specimens are often relatively higher. However, the young of all forms are much the same in outline. In the younger specimens the shell is more rectangular in outline, with the dorsal and ventral margins somewhat flattened, and the ends take on more slope and join the dorsal margin with angles. 
Comparisons.-Some large, long S. striatinum, particularly those of the central United States, reaching into Kansas, resemble $S$. sulcatum in outward appearance, but the usual S. sulcatum differs in that, although the striae on the beaks are coarse as in S. striatinum, over the rest of the shell the striae are less coarse and are uniform in size and spacing. In $S$. striatinum there is no uniformity in the striae. The ends of $S$. sulcatum are steeper, and the hinge is more nearly straight; the nepionic young are longer, more nearly rectangular and the margins less curved.

There is a large, long form of $S$. striatinum in the central states that has considerable resemblance to $S$. transversum. But in $S$. transversum the difference in height in front of and behind the beaks is much greater, the shell walls are thinner, the dorsal margin less curved, and there is a distinct jog in the hinge-plate behind the cardinals. See also s. fabale.

Habitat.-Creeks, rivers, large and small lakes. I have never found it in ponds, swamps or anywhere in stagnant water, but in sand or sandy gravel in creeks and rivers (even in sandy gravel in cracks in flat rocks), in sandy mud, but not in fine, soft mud. I have collected it in fine sand in two or three inches of water in small lakes, and Kenneth $G$. Wood collected many specimens in Lake Erie down to a depth of 13.5 meters. This species is our most common Sphaerium.

Geographic Distribution.-canada: New Brunswick, Quebec, Ontario (north to Moosonee, James Bay), Manitoba, Saskatchewan, Alberta, British Columbia, and Northwest Territories (Great Slave Lake). United states: Maine, Vermont, Massachusetts, Rhode Island, New York, New Jersey, Pennsylvania, Delaware, Maryland, District of Columbia, Virginia, N. Carolina, Kentucky, Tennessee, Mississippi, Alabama, Georgia, Florida, Ohio, Michigan, Indiana, Wisconsin, Illinois, Minnesota, N. Dakota, S. Dakota, Nebraska, Iowa, Missouri, Kansas, Arkansas, Louisiana, Texas, Montana, Wyoming, Washington, Oregon, Idaho, California, Nevada, Utah, Colorado, Arizona, and New Mexico. Mexico: Vera Cruz. Central america: Panama.

The oldest fossils of $S$. striatinum have been reported from the Middle Pleistocenc (Saw Rock Canyon fauna) Seward Co., Kansas, U.S.A. Various records exist for later periods.

\section{Sphaerium sulcatum (Lamarck) \\ (Pl. I, Fig. 1)}

1816, Cyclas similis Say (F. C. Baker, not Say, cf. Herrington, 1950b; 117).

1818, Cyclas sulcata Lamarck.

1901, Sphaerium crassum Sterki.

$1910 a$, Sphaerium lineatum Sterki.

1930, Sphaerium fallax Sterki.

Measurements.-UMMZ 200810. Scott Graham Creek, Carleton Co., Ontario. Length: 20.0, 14.5, 10.0, 7.2. Height: 14.5, 10.8, 7.6, 5.5. Diameter: 11.0, 7.6, 5.5, 3.1.

Diagnostic Characters.-Shell large, heavy, long in outline; beaks low, subcentral; striae heavy, more widely spaced around beaks than farther out, and of fairly uniform height; periostracum a dull gloss; dorsal margin long, slightly rounded; ventral margin long, a little more openly rounded; anterior end slightly rounded, steep but not vertical slope, joins dorsal margin with or without an angle and ventral margin low with a muchrounded angle: anterior and posterior ends similar; hinge long, very openly curved, narrowing somewhat and with a slight dip between cardinals and anterior cusps; hinge- 
plate rather long, moderately narrow; laterals short to medium in length; sometimes A I, and less frequently P I, dip below hinge-plate at their proximal ends; cusp of A I distal, moderately high but blunt on top, of P I somewhat distal or on distal side of center, low, an inclined plane, of A II central or on proximal or distal side of center, high, blunt on top; cusp of P II distal or on distal side of center, fairly prominent but blunt; cardinals nearer anterior cusps; C 3 parallel with hinge-plate, sometimes the anterior end long and extending along hinge-plate, sometimes (when shorter) curving slightly outward, a rounded curve followed by a slightly enlarged posterior end; $C 2$ parallel with hinge-plate and fairly close to its inner edge; C 4 weak, beginning outside $\mathrm{C} 2$ and curving well toward interior of shell. In specimens with a heavy hinge-plate $\mathrm{C} 2$ is farther back from the inner edge of the hinge-plate and more curved.

Comparisons.-See $S$. striatinum.

Habitat.-Small lakes, also eddies in rivers and creeks. It has a preference for soft sand with vegetation; never found in swamps or ponds.

Geographic Distribution.-Canada: Quebec, Ontario (north to James Bay), Manitoba, Saskatchewan, and Alberta. united states: Maine, Massachusetts, New York, New Jersey, Pennsylvania, Virginia, Ohio, Michigan, Indiana, Illinois, Minnesota, S. Dakota, Iowa, Montana, Wyoming, and Washington? (one old valve). Apparently it does not now extend south of the area covered by the glaciers.

Known as a fossil in the Sand Draw local fauna of Nebraskan age (Pleistocene), Kansas, U.S.A.

\section{Sphaerium transversum (Say)}

(P1. II, Fig. 6)

1829, Cyclas transversa Say.

1856, Sphaerium pallidium Gray.

1860b, Sphaerium subtransversum Prime.

Measurements.-UMMZ 200811. Rideau Canal, Hartwell Locks, Carleton Co., Ontario. Length: $12.5,9.9,8.0,3.9$. Height: $8.9,7.6,5.9,3.0$. Diameter: $6.0,5.1,3.8,1.8$. Specimens from some localities are much smaller. Specimens from Lake Ontario are larger; e.g., Sunnyside, Toronto, Ontario. L: 14.3, H: 10.5; D: 6.9.

Diagnostic Characters.-Shell quite large (but in some marginal localities rather small); long in outline; posterior end higher than anterior, walls thin; beaks nearer anterior end, the percentage with caps very small and then only weakly marked off; striae moderately fine, somewhat irregular; periostracum dull to slightly glossy; dorsal margin rather long, little curved, a jog at the beaks; ventral margin very gently curved, considerably longer than the dorsal; anterior end a steep slope with curvature of varying degrees or rounded, frequently joining dorsal margin with an angle, ventral margin without an angle; posterior end begins quite high, sloping outward with a somewhat rounded slope descending fairly low (adding to length of ventral margin) and joining margins with a rounded angle, or both margins without an angle; hinge long, slightly and irregularly curved; hinge-plate long, narrow, and forming a distinct jog behind cardinals; laterals distinct; laterals of right valve rather short, anterior one of left valve short; posterior lateral somewhat longer, a long inclined plane (there is a slight dip at the proximal end of the anterior laterals which gives them a shorter appearance and gives prominence to the cusps, all of which are blunt on top); cusps of P I, P II, and P III at distal end, of A III and A II usually distal, sometimes on distal side of center, 
of A I distal, on distal side of center, or central; cardinals near anterior cusps, weak; C 3 moderately short, parallel with hinge-plate, straight or slightly curved and only slightly enlarged at posterior end; C 2 short, straight or, rarely, curved outward at the ends; C 4 weak, short, very close to shell margin, straight or slightly curved, almost parallel with C 2, but space between them wider at anterior end, directed at or slightly inside or outside cusp of P II.

Comparisons.-See S. partumeium and S. striatinum.

Habitat.-Large lakes, rivers, and sloughs. Sterki (1909b) adds: "[S. transversum] is also found in rivers with strong current, with stony and rocky bottom." I have collected very few specimens of this species; it is rather scarce.

Geographic Distribution.-Canada: Quebec, Ontario, Manitoba, Saskatchewan, Alberta, and Northwest Territories (a small form in Tathlina Lake). UnITED sTATEs: New York, New Jersey, Pennsylvania, W. Virginia, North Carolina, Kentucky, Tennessee, Mississippi, Alabama, Georgia, Florida, Ohio, Michigan, Indiana, Wisconsin, Illinois, Minnesota, North Dakota, Nebraska, Iowa, Missouri, Oklahoma, Arkansas, Kansas, Louisiana, Texas, Montana, and Colorado. MEXICo. EURore. About 1850 this species was introduced into England and became known as $S$. pallidium Gray (1856). It was first collected in England in 1856 in a canal. It was afterward recovered from other localities. I have only one set from Exmouth and another from Lancashire.

S. transversum is known as a fossil from the Sand Draw and Dixon faunas (Early Pleistocene, Late Nebraskan age) and from the Late Pleistocene (Butler Spring fauna), Kansas, U.S.A.

GENUS PISIDIUM PFEIFFER, 1821

Type: Tellina amnica Müller, 1774

Pisidium adamsi Prime

(Pl. III, Fig. 5; Pl. VII, Fig. 5)

1851, Pisidium adamsi Prime.

1865, Pisidium adamsi Prime.

1901c, Pisidium affine Sterki.

1901 c, Pisidium sargenti Sterki. 1912c, Pisidium sphaericum Sterki. 1916b, Pisidium adamsi affine Sterki. 1922b, Pisidium deflexum Sterki.

Measurements.-Cotype from Maine, Prime's collection. Museum of Comparative Zoology, Cambridge, Massachusetts. MCZ 19782. Length, 7.2; Height, 6.3; Diameter, 4.7. UMMZ 198889. A dried up lake, 4 miles NW Keene, Otonabee Twp., Peterborough Co., Ontario, Canada. Length: 7.3, 5.6, 3.7, 1.6. Height: 6.3, 4.5, 3.2, 1.2. Diameter: 4.5, 3.1. 2.0, 0.7 .

Diagnostic Characters.-Shell very large and considerably inflated; beaks broad and full, many specimens with a flattening best seen in juvenile and nepionic shells; striae rather heavy and uniformly spaced; periostracum very dull; dorsal margin long and gently curved; anterior end rather steep, the slope slightly curved; posterior end truncate and vertical; ventral margin long and gently curved. Hinge long, openly curved and heavy; laterals heavy with heavy cusps, broad on top. Cusp of A I on the distal side of center; cusps of P I distal, of A II proximal, of P II on distal side of center; cardinals central or on anterior side of center; C $3 \mathrm{long}$, considerably curved, its posterior end a little enlarged; C 4 as long as, or longer than C 2, slightly curved and usually not directed 
toward interior of shell, but toward cusp of P II or just inside of it; C 2 varies in length, greatly curved or bent.

In the specimens described as $P$. sargenti and $P$. sphaericum the dorsal margin and hinge are considerably shorter. I do not recognize these as nomenclatorial entities.

The terms $P$. sphaericum and $P$. deflexum apply to extreme forms of $P$. adamsi. Both show signs of deformity, but intergrade with $P$. adamsi. The habitat of each is on the border of that of the average $P$. adamsi.

Comparisons.-Some large $P$. casertanum may easily be confused with $P$. adamsi as there is some resemblance in outward appearance, and the location of the cusps on the laterals is much the same. However, $P$. adamsi is very large with rather coarse striae, dull periostracum, long dorsal margin (except in the above mentioned $P$. sargenti and $P$. sphaericum), distinctly sloped anterior end, heavy laterals with blunt cusps, subcentral cardinals, and C 4 is directed toward cusp of P II or just inside instead of curving downward.

Habitat.-Small lakes, ponds, rivers, and (rarely) creeks. It has a preference for muck and decaying vegetable matter.

Geographic Distribution.-Canada: New Brunswick, Quebec, Ontario, and Saskatchewan. united states: Maine, New Hampshire, Massachusetts, New York, New Jersey, Pennslyvania, Delaware, Virginia (Sterki), Tennessee, Alabama, Georgia, Florida, Ohio, Michigan, Indiana, Wisconsin, Illinois, Iowa, Missouri, and Montana.

\section{Pisidium aequilaterale Prime}

(Pl. V, Fig. 1; Pl. VII, Fig. 13)

1851, Pisidium aequilaterale Prime.

1865, Pisidium aequilaterale Prime.

Measurements.-UMMZ 187792. Lake at mouth of small creek, Campbell's Bay, Mazinaw Lake, Lennox and Addington Co., Ontario. Length: 3.5, 3.0, 2.2, 1.6. Height: 3.4, 2.9, 1.9, 1.2. Diameter: $2.8,2.2,1.5,1.0$.

Diagnostic Characters.-Shell medium size, short, heavy; beaks central, large, broad, very high, full, and usually flattened a bit on top; striae moderately fine but distinct; periostracum moderately glossy; dorsal margin rather long and somewhat steeply rounded; ventral margin almost as long, but not quite as steeply rounded as dorsal; anterior end short and very steep, beginning at, or below, the anterior cusps and joining the ventral margin with an angle; posterior end round, joining dorsal and ventral margins without an angle; hinge well curved, long, almost full length of shell; hinge-plate heavy; laterals heavy, rather short, cusps blunt on top; cusps of A I distal, of P I on distal side of center or central, of A II distal or on distal side of center, of P II central; cardinals central, C 3 steeply curved, anterior end rather slim, C 2 varies in size, C 4 almost straight, directed toward cusp of P II; space between C 2 and C 4 is a slit directed toward cusp of P II. When a single valve is viewed from the inside, $P$. aequilaterale comes nearest to being round in outline of any of our Pisidium.

Comparisons.-Some heavy $P$. nitidum with a steep anterior end are much like some immature $P$. aequilaterale, but the beaks of $P$. aequilaterale are more prominent and swollen, the striae coarser, and the periostracum has less gloss.

The short, high form of $P$. variabile looks much like $P$. aequilaterale with respect to color, thickness of shell wall, height, hinge characters, and shape of the nepionic young. 
However, the anterior end of $P$. variabile is not as steep and the slope begins higher, the ventral margin is longer, the beaks are more toward the posterior end, the space between the posterior end of C 2 and C 4 is much greater, and the beaks of the nepionic young are not swollen at the middle in the same way.

Habitat.-Creeks, rivers, and lakes. Prefers small weeds on a fine sandy bottom. Almost all my specimens are from igneous rock formations. In the Mississippi River (Ontario) drainage system it is fairly abundant. Over 500 specimens were collected from a spot a rod square in the mouth of a creek in Mazinaw Lake.

Geographic Distribution.-Canada: Quebec and Ontario (east of Toronto). Unitren states: Maine, Vermont, Massachusetts, Rhode Island, New York, New Jersey, Pennsylvania, Virginia (Sterki), Michigan (Sterki), and Illinois.

\section{Pisidium amnicum (Müller)}

(P1. III, Fig. 2; Pl. VII, Fig. 2)

1774, Tellina amnica Müller.

1832, Pisidium amnicum Jenyns.

MEASUREMENTs.-UMMZ 194229. St. Lawrence River, in mouth of small creek, west side of Hudson's Pt., Leeds County, Ontario. Length: 9.7, 6.2, 4.7, 2.9. Height: 7.2, 4.6, 3.5, 2.1. Diameter: 5.3, 3.1, 2.4, 1.2. UMMZ 194277. Fiskebok, Sjolland Oht, Denmark. Collected by M. Steenberg. L: 11.9; H: 9.2; D: 7.5.

Diagnostic Characters.-Shell large, heavy, long; striae very coarse and rather uniform (specimens from some localities in Europe are almost free of these heavy striae); periostracum glossy; beaks rather far back, medium in height, and moderately narrow; dorsal margin very short, uniting with the anterior and posterior ends without an angle; anterior end a long slightly curved slope rounded at extreme end; ventral margin very long and slightly curved; posterior end truncated or extending outward somewhat; hinge of medium length, moderately heavy, rather far back, and evenly curved; cusp of A I and P I on distal side of center, of A II proximal or on proximal side of center, of P II central or on distal side of center; cardinals fairly close to anterior cusps; C. 2 resembles a large peg flattened on the anterior side, rounded on the posterior and outside; $\mathrm{C} 4 \mathrm{a}$ thinly curved wedge with thin end out; C 3 fits around C 2 with a rounded hollow, having a heavy posterior arm reaching to the inner edge of hinge-plate and a lighter anterior arm reaching half-way across hinge-plate; C 3 openly and steeply curved, making a good inverted $\mathrm{U}$.

Comparisons.-The resemblance to $P$. adamsi is chiefly in size. $P$. adamsi has a dull periostracum and the cardinals resemble those of $P$. casertanum.

There is a slight resemblance to $P$. dubium in size, shape, and surface appearance. However, $\boldsymbol{P}$. amnicum differs from $\boldsymbol{P}$. dubium in that the beaks are narrower and not as far back, the dorsal margin is shorter and the anterior slope not as straight and steep, the heavy uniform striae found on most $P$. amnicum cover most of the upper part of the shell, the cusp of A II is proximal (making the hinge appear short), and the outer side of C 2 is bluntly rounded, removing the cut-in-two appearance of C 3 and making C 3 have a rounded bend.

There is a long slim form of $P$. idahoense in Great Slave Lake, Northwest Territories, which has a strong resemblance to $P$. amnicum. These can be distinguished by the cardinals which, in $P$. idahoense, are much as in P. casertanum. 
Habitat.-On this continent it appears to have a preference for sandy bottoms of big waters. $P$. amnicum is not very plentiful in Europe, and very scarce in North America. It appears to be an introduced species here.

Geographic Distribution.-CANAda: St. Lawrence River, Ottawa River (around Ottawa), Bay of Quinte, and Lake Ontario. UNITED states: Lake Ontario (New York, F. C. Baker, 1901), Lake Erie (Ohio), Lake Huron (Michigan), Pennsylvania, New Jersey (Delaware R.), and Lake Champlain (New York or Vermont, Pilsbry, 1921). "Lake Ontario, probably introduced from Europe." Sterki (1916: 446). Africa: Egypt. vurasia.

\section{Pisidium casertanum (Poli)}

(Pl. IV, Fig. 1; P1. VII, Fig. 7)

1791, Cardium casertanum Poli.

1838, Pisidium cinereum Alder.

1841, Pisidium abditum Haldeman.

1841, Cyclas minor Adams, in Mighels and Adams.

1842, Cyclas steenbuchi Möller.

1843, Pisidum roseum Scholtz.

1851, Pisidium regulare Prime.

1853, Pisidium noveboracense Prime.

1865, Pisidium occidentale Newcomb.

1895c, Pisidium politum Sterki.

1896a, Pisidium randolphi Roper.

1896a, Pisidium trapezoideum Sterki.

1898b, Pisidium roperi Sterki.

1901 a, Pisidium streatori Sterki.

1902a, Pisidium strengi Sterki.

$1903 b$, Pisidium ashmuni Sterki.

1903 c, Pisidium complanatum Sterki.

1903 , Pisidium rowelli Sterki.

1903c, Pisidium cuneiforme Sterki.

$1905 \mathrm{~b}$, Pisidium atlanticum Sterki. 1906 , Pisidium proximum Sterki. 1906d, Pisidium subrotundum Sterki. 1906d, Pisidium friersoni Sterki. 1906f, Pisidium neglectum Sterki.

1906, Pisidium abditum huachucanum Pilsbry and Ferriss.

1907b, Pisidium superius Sterki.

1907 , Pisidium succineum Sterki.

1911 b, Pisidium albidum Sterki.

$1911 b$, Pisidium dispar Sterki.

1912c, Pisidium alleni Sterki.

1913, Pisidium columbianum Sterki.

1913, Pisidium furcatum Sterki.

1913, Pisidium nevadense Sterki.

$1916 b$, Pisidium elevatum Sterki.

$1916 b$, Pisidium ovum Sterki.

1916a, Pisidium hannai Sterki.

1916b, Pisidium fabale Sterki.

1922b, Pisidium parodoxum Sterki.

$1922 b$, Pisidium griseolum Sterki.

1922b, Pisidium orcasense Sterki.

1923, Pisidium lucidum Sterki.

1923, Pisidium mirum Sterki.

Measurements.-UMMZ 187048. Small roadside creek where road west from Keene crosses XII Concession of Otonabee, Ontario. Length: 4.1, 3.3, 2.7, 1.7. Height: 3.4, 2.8, 2.1, 1.3. Diameter: 2.8, 2.0, 1.6, 0.7. UMMZ 190461. Kitchen Creek, Lolo National Forest, Granite County, Montana. Collected by Royal Brunson. L: 8.2; H: 6.5; D: 4.5.

Diagnostic Characters.-The average shell is rather long in outline. Shell of moderate weight; beaks subcentral to a little farther back, not high; striae rather fine; periostracum moderately dull to slightly glossy; dorsal and ventral margins parallel and gently curved, dorsal margin usually joins ends with slight angles; anterior end moderately long and rounded; posterior end truncate; hinge-plate moderately long, fairly broad, laterals distinct, but not long; cusps on laterals rather sharp; cusp of A I on distal side of center, of A II proximal or on proximal side of center, of P II on distal side of center; P I and P III short, cusps distal; cardinals near anterior cusps; C 3 slightly curved and somewhat 
enlarged at posterior end, C 2 usually an inverted D, C 4 thin and more or less curved, directed toward interior of the shell.

Comparisons.-The hinge characters are much the same as in $P$. fallax; some $P$. casertanum have almost the same outline. However, the beaks of $P$. fallax depart more or less from the smooth form, some are flattened on top and some have incipient ridges. The shell is high rather than long, and the anterior end lacks the characteristic rounded end of $P$. casertanum. The periostracum has a degree of dullness never found in $P$. casertanum, and the hinge-plate is broad. The cusp of A II is twisted so that it is not parallel with the shell margin, but directed somewhat to the inside of the shell. This affects the cusp of A I and makes it extend inward causing the sulcus between A I and A III to be V-shaped.

There is a form of $P$. ferrugineum found in enlargements of creeks, among grass and weeds, and in association with a small, inflated form of $P$. casertanum, that resembles the young of $P$. casertanum. But the shell of these $P$. ferrugineum is long and well inflated. The beaks are low and about central, the anterior end round, the anterior laterals of the right valve short, the cusps sharp on top and a little more central than in P. casertanum, and the cusp of A II is high and toothpick-like, not a steep incline.

$P$. insigne can be mistaken for nepionic young of $P$. casertanum, but the beaks of $P$. insigne are almost central and more developed than in $P$. casertanum of the same size. The dorsal margin of $P$. insigne is more curved, the anterior slope not as steep, the anterior end more pointed, and the ventral margin not as curved. The posterior half of the shell is higher than the anterior; the highest part of the dorsal margin is immediately behind the cardinals and in many specimens this is conspicuous; the hinge is long; the cusps on A I and P I are distal; on A II the cusp is distal or on the distal side of center.

One form of $P$. casertanum has a long, downward-sloping anterior end that has some resemblance to that of $P$. subtruncatum and $P$. walkeri form mainense. But the hinge of $P$. casertanum is parallel with the ventral margin, and C 4 is curved downwards, so C 2 and $\mathrm{C} 4$ are not parallel as in $P$. subtruncatum and $P$. walkeri form mainense. The periostracum differs in each of the three species.

The variety $P$. casertanum ponderosum Stelfox approaches $P$. variabile somewhat closely in outline. But these short, high $P$. casertanum differ in that the cusp of A I is more central and that of P II is proximal. Also, the cardinals are usually nearer the anterior cusps.

For comparisons see $P$. adamsi.

Habitat. $-P$. casertanum has succeeded in adapting itself to a wide variety of habitats. One finds it in bog ponds, ponds, swamps that dry up for several months of the year, swamp-creeks, creeks with considerable current, rivers, and lakes, including the Great Lakes. This is by far the most common Pisidium.

Grographic Distribution.-Canada: There are records for the occurrence of $P$. casertanum throughout the country from Newfoundland and Labrador to British Columbia, and as far north as the Arctic Circle. United states. It is found in all of the States except Hawaii, Kentucky, and North Dakota. mexico. Caribbean arfa: Cuba, Puerto Rico. central and south america: Honduras, Brazil, Patagonia. eurasia: the most widely distributed Pisidium. australian area: Australia, New Zealand, Tasmania. africa: as far south as Rhodesia.

Quite modern looking specimens have been recorded as fossils from the Laverne Formation of the Lower Pliocene in Beaver Co., Oklahoma, U.S.A. 


\section{Pisidium compressum Prime}

(Pl. V, Fig. 2; Pl. VII, Fig. 14)

1851, Pisidium compressum Prime.

1865, Pisidium compressum Prime.

Measurements.-UMMZ 199141. Rice Lake, Birdsall Beach, Otonabee Twp., Peterborough Co., Ontario. Length: 3.8, 3.1, 2.4, 1.8. Height: 3.8, 2.8, 2.1, 1.6. Diameter: 2.7, $2.0,1.3,1.0$.

Diagnostic Characters.-Shell of medium size, heavy, varying from short and high to moderately long; beaks rather prominent, quite far back, narrow and usually with ridges; striae of medium coarseness to moderately fine; periostracum dull; dorsal margin short and round; anterior end begins near beaks without an angle, has a rather steep slope becoming almost straight, the steeper end near proximal side of cusps descending low to where it joins ventral margin with an angle; ventral margin long (three times that of the dorsal) and considerably curved, passing into the posterior end without an angle; posterior end broadly rounded, vertical or slightly cut under; hinge long, heavy, and moderately to steeply curved; laterals rather short, being incorporated into the hingeplate; A III and P III tend to curve around the pit of the sulcus, cusps blunt on top; cusp of A I distal, of P I, A II, and P II central or on distal side of center; cardinals central; C 3 short, considerably curved, posterior end much the larger; $C 2$ short and stout like an inverted D; C 4 rather short, slightly curved, and directed toward cusp of P II; space between posterior end of C 2 and $C 4$ considerable.

Comparisons.-The general outline of the shell is much the same as in $P$. henslowanum form supinum. Both have ridges on the beaks, a steep anterior slope, and a heavy, much-curved hinge. However, the ridges on the beaks of form supinum resemble those in $\boldsymbol{P}$. lilljeborgi form cristatum and $\boldsymbol{P}$. henslowanum; the striae are more widely spaced, the hinge shorter, and the cusp of A II is proximal.

The hinge characters are almost exactly the same as in P. ultramontanum. But $P$. ultramontanum is considerably larger, more nearly round in outline, the diameter is less, and many shells have a number of ridges interspersed among the finer striae.

The hingc characters and outline of the shell of most specimens are the same in $P$. variabile, but the periostracum of $P$. compressum is dull, not glossy, and the beaks narrow and usually ridged. The striae also differ considerably.

HaвiтAт.-Crceks, rivers, and lakes. It has a preference for sandy bottoms with vegetation, and shallow water, but Kenneth G. Wood collected it at 16 meters in the western cnd of Lakc Erie, and I brought it up from a depth of 20 meters in Mazinaw Lake, Lcnnox and Addington Co., Ontario. Sterki (1916b: 447) states: "the river and creek form is regarded as typical." Next to P. casertanum it is the most common Pisidium in North America.

Grographic Distribution.-Canada: Prince Edward Island, Quebec, Ontario, Saskatchcwan, Alberta, British Columbia, and Northwest Territories to Great Slave Lake. UNiteD srates: Maine, Vermont, Massachusetts, New York, New Jersey, District of Columbia, Tenncssee, Georgia, Alabama, Ohio, Michigan, Indiana, Wisconsin, Illinois, Minnesota, North Dakota, South Dakota, Iowa, Texas, Montana, Wyoming, Washington, Oregon, Idaho, California, Nevada, Utah, Colorado, Arizona, New Mexico, and Alaska. Mexico.

Fossil $P$. compressum is known from the Middle Pliocene onwards. The earliest record is from the Ogallala Formation (Pre-Buis ranch fauna) of the High Plains region, U.S.A. 


\section{Pisidium conventus Clessin \\ (Pl. VI, Fig. 6; PI. VII, Fig. 22)}

1877, Pisidium conventus Clessin.11

1898 , Pisidium abyssorum Sterki.

1923, Pisidium hendersoni Sterki.

Measurements.-UMMZ 194656. Amethyst Lake, Jasper National Park, Alberta (Altitude 6451 feet). Collected by D. S. Rawson. Length: 3.2, 2.5, 1.8, 1.3. Height: 2.8, 2.2, 1.6, 1.0. Diameter: 2.0, 1.3, 1.0, 0.5.

Diagnostic Characters.-Shell small, thin; specimens vary greatly in outline when occurring in deep water of small lakes, or in large lakes; shells from small lakes of high altitude tend to be larger and less angular; beaks subcentral to somewhat posterior, broad and not prominent; in some specimens there is a flattening, the beginning of a wrinkle or ridge; striae fine, but usually even and distinct; periostracum dull to a dull gloss; the so-called "rest periods" are distinct, evenly spaced and like those in some small-creek specimens of $P$. casertanum; dorsal margin rather long, openly curved, with something of a bend at the beaks; anterior end a long slope, sometimes rounded; posterior end frequently sloped at same angle as anterior end, making ends parallel, but sometimes more rounded, and even vertical; ventral margin gently curved; hinge usually slightly bent at beaks, long, and the plate narrow; laterals long and slender; cusps of A I, P I, and A II distal or on distal side of center, of P II distal; cardinals central or subcentral; C 2 at or on proximal end of A II, short, close to inner edge of hinge-plate or overhanging, and either about parallel with hinge-plate or with posterior end slightly more interior; C 4 slightly longer than C 2, slimmer, straight or slightly curved, beginning above center of $\mathrm{C} 2$ and parallel with it, or its posterior end directed a little more toward the interior; C 3 moderately long, slightly curved, almost parallel with hinge-platc, posterior end cnlarged somewhat, therefore, nearer inner cdgc of hinge-plate.

Comparisons. -The cold-water habitat scparates $P$. conventus from all other species it otherwise resembles.

The hinge in both $P$. conventus and $P$. insigne is long, but the cardinals of the left valve of $P$. insigne are anterior, the shell is longer in outline and has a pointed anterior cnd, and it is a small-creek species.

$P$. conventus is much the same in size as $P$. punctiferum, but is differently striated and is a cold-water species found only at high altitudes, in decp water, or in high latitudes.

Habitat. $P$. conventus apparently cannot stand warm water. It is found only in the Far North where it will be found even along the shore or, when collected farther south, at high altitudes or in deep water (Herrington, 1950: 31). On July 2, 1947, D. S. Rawson's party brought up a live adult from a depth of 219 meters in Hearne Channel, Great Slave Lake, Northwest Territories (Herrington, 1950: 26).

Geographic Distribution.-Canada: Quebec, Ontario, Saskatchewan, Alberta, and Northwest Territories (north to Great Bear Lake). United sfates: Alaska, Washington, Colorado, New York (Cayuga Lake), Lake Superior, and Lake Michigan. vurasıs: as far north as Novaya Zemlya.

11 The European species $P$. clessini Surbeck, 1899, P. tornense Odhner, 1908, $P$. pusillum Woodward (non Jenyns), 1913, and P. conventus Odhner, 1923, are considered identical with $P$. conventus Clessin by Odhner $(1921,1923 b)$ on the basis of anatomical investigation. 


\section{Pisidium cruciatum Sterki}

(Pl. V, Fig. 5; Pl. VII, Fig. 16)

1895b. Pisidium cruciatum Sterki.

Measurements.-A juvenile from Joliet, Illinois. Length, 1.3; Height, 1.1; Diameter 0.7.

Dragnostic Characters.-Shell heavy, very small; beaks prominent, far back, with ridges; striae fairly coarse; periostracum dull; dorsal margin very short and round; anterior end, beginning at or above anterior cusps, a long, straight, or slightly curving slope joining the ventral margin low with a rounded angle; ventral margin long and but little curved; posterior end truncate to slightly curved, vertical or even sloping backward, and joining ventral margin with an angle; hinge long and steeply curved; hinge-plate heavy; laterals heavy and short, little more than cusps; cusps of A I and P I distal, of A II central or on either proximal or distal side of center, of P II on distal side of center; cardinals central; C 2 heavy, usually an inverted D; C 4 slim, slightly curved and directed toward cusp of P II or slightly inside; C 3 parallel with hinge-plate, curved somewhat on the outside, the (greatly enlarged) posterior end making the inside considerably curved; ligament pit very short and wide, width almost equalling length, and deepening as it approaches inside of hinge-plate where it breaks through, resembling in this respect the European species $P$. vincentianum.

Comparisons. $-P$. cruciatum appears to have no close rescmblance to any other Pisidium.

HaвiтA'.-"They live in mud among aquatic plants and dead leaves, and, as a rule, are covered with a black or brown coat, sometimes so thick that they appear to be globules of dirt ..." (Sterki, 1895b: 98-99).

Grographic Distribution.-Canada: I have two specimens from two stations on the Thames River, London, Ontario. united states: Ohio, Michigan, Illinois. Sterki (1916b: 149) adds "Missouri, Arkansas, Alabama"; Baker (1928a: 377), "Wisconsin."

\section{Pisidium dubium (Say)}

(Pl. III, Fig. 1; P1. VII, Fig. 1)

1816, Cyclas dubia Say.

1820, Phymesoda equalis Rafinesque.

1841, Pisidium abruptum Haldeman.
1851, Pisidium dubium Prime.

1865, Pisidium virginicum Prime. $1916 b$, Pisidium virginicum Sterki.

(See Nautilus 59: 86-87, for Pilsbry's statement.)

Mrasurements.-UMMZ 194128. Ouse River, Asphodel Twp., Peterborough Co. Ontario. Length: 9.0, 7.0, 5.0, 3.0. Height: 8.0, 5.75, 4.0, 2.25. Diameter: 5.5, 4.0, 2.25, 1.25 .

Diagnostic Characters. - Shell very large, heavy, moderately long and considerably inflated; beaks very broad, rather prominent, smooth on top, and placed so far back that in adults there is no dorsal margin behind them; striae coarse, irregular, showing very little on upper part of shell, which is rather smooth; periostracum dull to slightly glossy; dorsal margin gently curved toward anterior end, but steeply curved at posterior end, joining posterior end at about middle of ligament pit; posterior end truncate and vertical (a steep flexure between cardinals and posterior cusps; posterior cusps become part of posterior end of shell and are parallel with anterior end, whereas anterior cusps are parallel with ventral margin); anterior end rather steep from anterior cusps down to 
where it joins ventral margin by a curvc; ventral margin rather long, considerably curved, joins ends without an angle; hinge heavy, widened at cardinals and greatly bent behind them; laterals rather short, little more than cusps, and cusps blunt; laterals of right valve divided by a deep pit to receive cusps of left valve; cusps of A I and P I on distal side of center, of A II on distal side of center or distal, of P II distal; cardinals central or even somewhat toward posterior cusps (this condition has been noticed in no other species). The cardinals are unusual; there is a strong resemblance between those of the left valve and the one of the right valve; the inner ends of $\mathrm{C} 2$ and $\mathrm{C} 4$, and the posterior end of $\mathrm{C} \mathrm{3}$, all reach the inner edge of the hinge-plate; the outer ends of $\mathrm{C} 2$ and $\mathrm{C} 4$, and the center of $\mathrm{C} 3$ reach or almost reach the outer edge of the hinge-plate. Sometimes the anterior end of $\mathrm{C} 3$ starts at the inner edge of the hinge-plate; the explanation is that $\mathrm{C} 2$ is broad where it is incorporated with the hinge-plate at its inner edge, and curves slightly as it extends across the hinge-plate almost to the outer edge. Here, this cardinal ends in a fairly sharp curved point. C 4 (to start at the opposite end this time) starts very narrow, almost touches the outer point of $\mathrm{C} 2$, curves slightly as it swings away from $\mathrm{C} 2$ in crossing the hinge-plate, and ends rather broadly. There is almost no outer space between C 2 and C 4; the inner space is approximately the same width as the inner end of C 2 or C 4 . The greatly curved C 3 fits into the cavity betwecn these two and is almost cut in two by the outer sharp ends of C 2 and C 4. (This may have led to the earliest statement that the cardinal of the right valve of Pisidium is "double.") C 4 is usually a curved wedge. Because the beaks are so far back the ligament pit is pretty much a part of the posterior end rather than of the dorsal margin, making the shell open more endways than off the dorsal margin.

Comparisons.-See P. amnicum.

Habitat. $-P$. dubium has a preference for large, muddy creeks. But $I$ have found live individuals in fine sand near shore in Rice Lake, Peterborough Co., Ontario, and in 34 fect of water in the St. Lawrence River near Grenadier Island.

Geographic Distribution.-Sterki (1916b: 446) states; "East of the Rocky Mountains, north to Yukon and Alaska." But all the records I have arc: CANADA: Ontario (Lake Ontario and St. Lawrence River drainage, and Ottawa River near Ottawa); UNITEd STATEs: Vermont, Massachusetts, New York, New Jersey, Pennsylvania, District of Columbia, Virginia, South Carolina, Tennessce, Alabama, Georgia, Florida and Michigan.

\section{Pisidium fallax Sterki}

(Pl. IV, Fig. 5; Pl. VII, Fig. 11)

1896c, Pisidium fallax Sterki.

1899a, Pisidium kirklandi Sterki.

MeAsurements.-UMMZ 194176. Indian River, Otonabec Twp., Peterborough Co., Ontario. Length: $3.5,2.8,2.3,1.7$. Height: $3.1,2.5,1.9,1.5$. Diameter: $2.0,1.4,1.1,0.8$.

Diagnostic Cinaracters.-Shell small to medium size, short, usually of littlc diametcr. walls of medium thickness; beaks subcentral, somc fairly plain, some flattened a little and some having low ridges; striae moderately coarse; periostracum very dull; dorsal and ventral margins slightly curved; anterior end rather short, steep, the slope more or less curved; posterior end truncated, vertical; hinge very broad and moderately long; laterals not very long; cusps mostly low and not very sharp; cusps of A I central or on proximal side of center, usually leaning inward (the hinge-plate is much widened here); cusps of 
P I central, of P II central or on proximal side of center, of A II central or on proximal side of center, not at center of hinge-plate but well inside, which gives it the appearance of a twist so that it is not parallel with the shell margin or directed across it, but directed somewhat inward. This accounts for the great width at A I. A I and A III not parallel, but somewhat $\mathrm{V}$-shaped. The cardinals are subcentral to near the anterior cusps; C 2 an inverted D; C 4 straight or a little curved and directed slightly inside cusps of P II; C 3 mostly short, much curved and directed across the hinge-plate, but it varies considerably.

Comparisons.-See $P$. casertanum.

Habitat. $-P$. fallax has a preference for coarse sand or gravel, even sandy gravel in cracks on a flat rock bottom (specimens from sand are more apt to have the peculiar $P$. fallax beaks than are those from gravel). It appears to like water in motion, i.e., large creeks, rivers, or lakes and bays where there is considerable wave action. This species is rather scarce, has a spotty distribution, and usually only a few specimens are found in a place.

Geographic Distribution.-CANAda: Ontario, Saskatchewan, and Northwest Territories (Great Slave Lake). united STATEs: Maine (Sterki), New York, New Jersey, Alabama, Ohio, Michigan, Illinois (Sterki), Minnesota (Sterki), Iowa, and Washington.

\section{Pisidium ferrugineum Prime}

(Pl. IV, Fig. 6; Pl. VII, Fig. 12)

1851, Pisidium ferrugineum Prime.

1865, Pisidium ferrugineum Prime.

1894, Fossarina hibernicum Westerlund. 1899a, Pisidium medianum Sterki. 1903a, Pisidium costatum Sterki. $1916 b$, Pisidium vexum Sterki.

Measurements.-UMMZ 189936. Camden Lake, Camden Twp., Lennox and Addington Co., Ontario. A form with short dorsal margin and long slope. Length: 2.8; 2.4, 2.0, 1.3. Height: $2.5,2.1,1.6,1.1$. Diameter: $2.2,1.9,1.6,0.9$.

Diagnostic Characters.-Shell small, usually much inflated, walls thin; beaks subcentral, tubercular, plain, or even low and broad; they usually do not blend into shell readily; striae coarse to faint; periostracum glossy; dorsal margin rounded, length variable; ventral margin rounded much as dorsal, but longer; posterior end rounded, vertical or even extending outward near ventral margin, rarely cut under; anterior end with greater or less degree of slope depending on length of dorsal margin, joins ventral margin without an angle; hinge-plate narrow and light; laterals short with rather pointed cusps; sometimes inner laterals of right valve are curved outward at their outer ends; cusps of A I central or on distal side of center, of A II central or on proximal side of center, of P II fairly distal (cusps of A II and P II are short and high with near-vertical ends); cardinals straight or slightly curved, very small and near anterior cusps, particularly in specimens with short dorsal margin; C 2 and C 4 roughly parallel with each other, but not with the hinge-plate as the space between them more often runs diagonally across it.

The type specimens of $P$. ferrugineum in Prime's collection at the Museum of Comparative Zoology, Cambridge, Massachusetts, are rather long, have a rounded anterior end and tubercular beaks. Specimens of similar outline without tubercular beaks are common; very common are specimens with the dorsal margin shorter, with tubercular beaks in varying degrees of development, and with the anterior end having different degrees of slope and making a certain angle where it joins the ventral margin. Specimens with the anterior 
slope and angle, but without the tubercular beaks, are also common (Herrington 1954: $100)$.

Prime (1851) stated "The specimens are generally found covered with a fine red mud, much the color of oxide of iron." And in 1865 he wrote "of large tubercles which are generally coated with some dark ferruginous substance." As this is not a constant feature of the specimens of this species, and not peculiar to it (Jenyns uses this as a distinguishing character of $P$. henslowanum-“... at the apex, covered over with dirty rust colour"), I have disregarded it in my diagnostic characters.

The ecological form $P$. ferrugineum medianum has subcentral beaks that are not tubercular. The ecological form $P$. ferrugineum costatum is short and greatly inflated; it has marked rest periods; the beaks are low, broad and rather posterior; and the hinge is very narrow.

The European form P. ferrugineum hibernicum tends to be less inflated, with more striae, prominent beaks, and a more curved, or even bent dorsal margin. All North American forms are found in Europe, but in smaller numbers.

Comparisons.-There is a form of $P$. ferrugineum that is very much like a form of $P$. nitidum. But the beaks of $P$. ferrugineum are more swollen and do not blend with the body of the shell; the hinge is slightly shorter, the cardinals closer to the anterior cusps, and the anterior cusps are not so distal and are more sharply pointed.

Prime's type specimens were with $P$. nitidum form pauperculum (at least in Sterki's time; I separated them in 1948). This confused Sterki for some years (1896d: 64-66). The beaks of the form pauperculum are more posterior than in nitidum and are not marked off from the shell; the posterior end is not vertical, but cuts under; the anterior end is steep from the cusps down; the laterals are large and heavy with blunt cusps; and the cardinals are central.

The form costatum is sometimes much like some $P$. obtusale. But $P$. obtusale is higher toward the posterior end in proportion to the anterior, the anterior end is without a slope, the hinge shorter, the cusp of A II proximal, and the posterior sulcus of the right valve is blocked at its proximal end by a pseudocallus.

Habitat. $P$. ferrugineum has a preference for cool climates. When found on a sandy bottom the striae are prominent and the beaks more or less tubercular. Those specimens obtained from lakes that are filling up with marl or developing a mucky bottom are smoother, have a greater diameter, and the beaks do not have the tubercular appearance. The varieties are much more common than the typical form with its strange tubercular beaks. Found in lakes, creeks, and rivers.

Geographic Distribution.-Canada: New Brunswick, Quebec, Ontario, Manitoba, Saskatchewan, Alberta, British Columbia, Northwest Territories. United states: Maine, Massachusetts, New York, New Jersey, Ohio, Michigan, Indiana, Illinois, Montana, Wyoming, Washington, Oregon, California, and Utah. EURoPE.

$P$. ferrugineum is also known as a fossil from Late Pleistocene deposits (Jones fauna), Meade Co., Kansas, U.S.A. 
Pisidium henslowanum (Sheppard)

(Pl. V, Fig. 4; Pl. VI, Fig. 3; Pl. VII, Fig. 20)

1825, Tellina henslowana, Leach MS., Sheppard.

1850, Pisidium supinum Schmidt.

Measurements.-UMMZ 198568. Bay of Quinte, Carrying Place, Ameliasburg Twp., Prince Edward Co., Ontario. Length: 4.0, 3.0, 2.3, 1.6. Height: 3.6, 2.5, 1.8, 1.3. Diameter: 2.4, 1.5, 1.0, 0.8. Lake Ontario, Prince Edward Co., Ontario. Shore debris. Form supinum. L: $3.2,2.7,2.2,1.7$. H: $3.0,2.4,2.0,1.6$. D: $2.0,1.6,1.3,1.0$. Specimens from the Ottawa River, Ontario, are larger than those from Lake Ontario.

Diagnostic Characters.-Shell light in weight, of medium size, usually of small diameter, and usually rather long and pointed at the anterior end, the point toward the ventral end; striae of medium coarseness; periostracum moderately dull; beaks narrow and moderately high, usually with ridges; dorsal margin short, tilted somewhat backward, joining ends with angles (best seen in immature specimens and in the form supinum); anterior end a fairly straight slope beginning at cusps and joining ventral margin with roundly pointed angle; ventral margin gently to much rounded, depending on length of shell, joining posterior end without angle; posterior end truncate and vertical; hinge rather short, gently curved, tilted backward; laterals mostly short; cusp of A I central to somewhat distal, of P I distal or on distal side of center, of A II proximal, of P II distal; cardinals near anterior cusps; C 3 considerably curved, enlarged at posterior end,

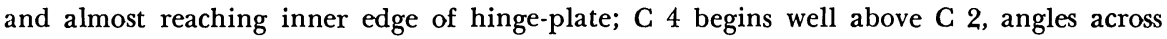
hinge-plate, but not as curved downward as in casertanum; C 2 somewhat as in casertanum, posterior end much curved and anterior end begins back from inner edge of hinge-plate.

The form $P$. henslowanum supinum differs from $P$. henslowanum s.s. by being shorter, heavier, with more widely spaced striae, and cardinals farther from the anterior cusps.

Comparisons. $-P$. lilljeborgi form cristatum Sterki has ridges on the beaks similar to those of $\boldsymbol{P}$. henslowanum and might be mistaken for a short form of the latter. But it is more inflated with the striae coarser and of a different kind, the anterior end more rounded, and the periostracum not so dull (aside from the ridges on the beaks, the form cristatum is like $P$. lilljeborgi rather than $P$. henslowanum).

Both $P$. henslowanum and $P$. subtruncatum have a tilted dorsal margin and a long anterior slope. However, $P$. henslowanum has narrower beaks, usually with ridges, and the beaks are not as tilted, they are not marked on the body of the shell, and the periostracum is not glossy but moderately dull. In addition, the cardinals usually show the following differences: C 3 is more curved and its posterior end enlarged; C 2 and C 4 are diagonal to the hinge-plate rather than nearly parallel; C 2 is considerably heavier than $\mathrm{C} 4$ and not lamelliform but much curved or bent.

Habitat.-In North America at least, $P$. henslowanum is not found in creeks, small rivers, ponds, or small lakes. In Europe it appears to be fairly common, in North America, rare. I have found it from only seven localities, mostly in shore debris.

Geographic Distribution.-Canada: Ontario (Lake Ontario, Bay of Quinte, Rideau River, and St. Lawrence River-all connected). UNITED states: Michigan (Lake Michigan off Grand Haven; collected in 1960). Sterki (1916b: 449) gives Lake Champlain and cites Dall, "Lake Superior to Lake Winnipeg." This species appears to be introduced. However, fossil specimens that were typical for the form supinum were recovered in numbers by the U.S. Geological Survey from the Upper Pliocene and Early Pleistocene of Idaho. Eurasia. ICFI.AND. 


\section{Pisidium idahoense Roper \\ (Pl. III, Fig. 3; P1. VII, Fig. 3)}

1890, Pisidium idahoense Roper.

MeAsurements.-UMMZ. 194204. Selected shells collected by Randolph, 1896. Washington State. Length: 10.3, 8.3, 6.5. Height: 9.5, 7.1, 5.3. Diameter: 7.0, 5.0, 3.7. UMM/2 194209. Floor of drained lake, Seward Peninsula, Alaska. Collected by W. B. Quay. L, 11.7; H. 9.8; D. 6.6 .

Diagnostic Characters.-Shell very large (some high, short, of great diameter, and very heavy; others high, of moderate diameter and weight, and longer); beaks low and broad; periostracum glossy; striae fine; dorsal margin very short and steeply rounded, joining anterior and posterior ends with very slight angle; anterior end a well-rounded, rather steep slope, joining ventral margin without angle; posterior end rounded; ventral margin well rounded; hinge moderately heavy, rather long and considerably curved; laterals in large specimens short; cusps rather blunt on top; cusp of A I on distal side of center or distal, of P I distal, of A II proximal or on proximal side of center, of P II central; cardinals slightly nearer anterior cusps; C. 2 very short and curved or forming an inverted D; C 4 much longer, straight or but slightly curved and directed toward cusp of P II or a little inside; C 3 rather long and considerably curved, about parallel with hinge-plate, center frequently much thinner than ends, posterior end slightly more enlarged than the anterior.

Comparisons. $-P$. idahoense is so different in outline from all other species of Pisidium that there is little danger of confusing it with anything else. Mention need be made only of some specimens found in Great Slave Lake, Northwest Territories, that are longer in outline than usual, and therefore have some resemblance to faintly striated P. amnicum, but the cardinals easily distinguish them.

Habitat.-Apparently, it lives in cool water-in large lakes, mountain regions, and the Far North. In Great Slave Lake, Northwest Territories, it has been collected at a depth of 24 meters (Herrington 1950a: 26). Roper (1890) collected it "in a muddy slough ... northern Idaho."

Geographic Distribution.-Canada: Prince Edward Island, Ontario, Saskatchewan, Alberta, and Northwest Territories (north to Great Bear Lake). UNITFD STATFs: Ohio (Lake Ontario), Indiana, Michigan (Hunt Creek, Ogemaw Co.), Wisconsin (Baker 1928a: 369), Montana, Washington, California, Idaho, and Aleutian Islands (Unimak Island).

\section{Pisidium insigne Gabb \\ (Pl. VI, Fig. 5; Pl. VII, Fig. 21)}

1868, Pisidium insigne Gabb.

MeAsurements.-UMMZ 188251. Spring Creek, Newburgh cheese factory, Camden Twp., Lennox and Addington Co., Ontario. Length: 2.2, 1.9, 1.7, 1.5. Height: 1.8, 1.6, 1.4, 1.1. Diameter: $1.3,1.1,0.8,0.7$.

Diagnostic Charactrrs.-Shell very small, long, small diameter, walls rather thin; beaks low, only slightly posterior; striae fine to very fine, somewhat irregular; periostracum slightly glossy, usually obscured by foreign substances; dorsal margin rather long and openly curved, sometimes with a slight bend at the beaks: anterior end roundly pointed; ventral 
margin fairly straight; posterior end truncate to roundly truncate, sometimes with an angle where it joins dorsal margin; hinge long and openly curved, sometimes with a bend at or near the cardinals; hinge-plate narrow; laterals long and slim, cusps rather sharp on top; cusp of A II distal or on distal side of center, of P II very distal (the distance from this cusp to the cardinals seems very great), of A I distal or on distal side of center, of P I distal; cardinals of right valve subcentral or nearer anterior cusps; C 2 small, almost straight, parallel with inside of hinge-plate; C 4 small, rather indistinct, slightly curved, almost parallel with C 2, posterior end a little nearer inside of hinge-plate and a little more posterior than C 2; C 3 slim, straight, or slightly curved, frequently slightly enlarged at posterior end, which is a little nearer the inside of hinge-plate.

Comparisons. - With nepionic shells of $P$. casertanum, see $P$. casertanum; with $P$. conventus, see under that species.

Habitat.-Mostly in creeks in low spots, i.e., slow-moving creeks or spring creeks.

Geographic Distribution.-Canada: Ontario (southern part, Muskoka District, east of Toronto), British Columbia. UnIted states: Maine, New York, Michigan, Montana (Sterki), Wyoming, Washington, Oregon, Idaho, California, Nevada, Colorado, Arizona, and New Mexico.

\section{Pisidium lilljeborgi Clessin \\ (Pl. IV, Fig. 2; Pl. VII, Fig. 8)}

1886, Pisidium lilljeborgi Clessin, in Esmark and Hoyer.

1896d, Pisidium scutellatum Sterki.

1928, Pisidum scutellatum cristatum Sterki.

Measurements.-UMMZ 195574. Rice Lake, Birdsall Beach, Otonabee Twp., Peterborough Co., Ontario. Length: 3.8, 3.1, 2.4, 1.7. Height: 3.2, 2.6, 2.0, 1.4. Diameter: 2.5, 2.0, 1.3, 0.9.

Diagnostic Characters.-Shell short, moderately large, walls thin, usually considerably inflated, asymmetrical; beaks very prominent, fairly far back, broad and full, but more upright and blending into the shell than is the case with $P$. subtruncatum; striae ranging from moderately fine to rather coarse; periostracum slightly dull to moderately glossy; dorsal margin very short, far back, openly curved and usually joining the ends with angles; posterior end roundly truncate, vertical, joining ventral margin imperceptibly; anterior end a very long, somewhat rounded slope, joining ventral margin low with a more or less rounded angle; ventral margin long, well curved and swinging up at the posterior end where it passes into the dorsal margin (in many specimens the posterior end and the back part of the ventral margin make the segment of a circle); hinge short, openly curved; hinge-plate moderately heavy; laterals A I, A II, and P II moderately long (A I and A III form a V); cusp of A I proximal or on proximal side of center, or central (somewhat blunt on top), of A II proximal (high and sharp on top), of P II distal (high, a rather steep incline and sharp on top); cardinals close to anterior cusps; C 3 rather long, usually bent with anterior end parallel with hinge-plate, posterior end quite expanded; C 2 short and broad; C 4 narrow, twice or more as long as C 2, beginning outside and extending straight (or in a gentle curve) back diagonally along hinge-plate to below its center, placing the posterior end of $\mathrm{C} 2$ and $\mathrm{C} 4$ quite a distance apart.

In $P$. lilljeborgi the ventral margin swings high at the posterior end, thus making the height of the posterior end of the shell much less than that of the anterior end; the dorsal margin is not parallel with the ventral margin. 
There is a form of $P$. lilljeborgi, found plentifully in Michigan, that is much longer in outline than the above, and longer than is usual for the species in other parts of the world.

The form $P$. lilljeborgi cristatum differs from the type in having ridges on the beaks; the shell is usually shorter.

Comparisons.-See $P$. henslowanum. A North American form of $P$. subtruncatum occurs in the western part of the United States and in Canada north to Great Slave Lake, Northwest Territories, which may easily be confused with $P$. lilljeborgi. These $P$. subtruncatum have a longer, less curved, anterior slope; the beaks are farther back, have a greater tilt and do not blend so quickly into the body of the shell; the cardinals of the left valve are more nearly alike, and more nearly parallel; and the cusp of A I is more proximal. On the whole these western specimens have a greater affinity with $P$. subtruncatum than with $P$. lilljeborgi, and intergrade with it in Great Slave Lake and in Lake Athabaska.

Habitat.-Lakes and rivers, with a preference for lakes; found in fine sand containing scattered small weeds. Fairly common in some localities; quite common in Europe.

Geographic Distribution.-canada: Quebec, Ontario, Saskatchewan, Alberta, and Northwest Territories (north to Great Bear Lake). UNiTED states: Vermont, Massachusetts, New York, Michigan, Indiana, Wisconsin, Montana, Washington, California, Utah, Colorado, and Aleutian Islands. Europe (north to Outer Hebrides). ICELAND.

$P$. lilljeborgi has been reported from Late Pleistocene deposits of Wisconsin age (Vanhem formation, Jones sink and Jones faunas), Meade Co., Kansas, U.S.A.

\section{Pisidium milium Held \\ (Pl. IV, Fig. 3; Pl. VII, Fig. 9)}

1836, Pisidium milium Held.

Measurements.-UMMZ 193966. Denbigh Lake, Denbigh Twp., Lennox and Addington Co., Ontario. Length: 2.9, 2.5, 2.2, 1.7. Height: 2.3, 1.9, 1.7, 1.4. Diameter: 2.0, 1.6, 1.4, 1.0.

Diagnostic Characters.-Shell small, long; walls thin, much inflated; beaks rather far back, considerably swollen and prominent; periostracum very glossy; striae rather widely spaced, but frequently low; "rest periods" quite prominent; dorsal and ventral margins parallel; dorsal margin short and considerably curved; ventral margin long and almost straight; posterior end truncate or rounded, almost vertical, and at right angles to both dorsal and ventral margins; anterior end a long, rather steep slope descending very low to where it joins the ventral margin with a sharp angle; hinge-plate narrow and not very long; laterals rather short; cusps inclined to be sharp on top; cusps of left valve toothpick-like, of A I and A II central or on distal side of center, of P II somewhat distal; cardinals fairly near anterior cusps, but varying, sometimes subcentral; C 3 slightly curved and uniform in width; C 2 and C 4 nearly same thickness and about parallel; C 4 begins well over C 2, slightly curving or straight (C 2 is the shorter of the two).

Comparisons.-Some $P$. nitidum approach $P$. milium in having the point of juncture of the ventral margin and the anterior end low; both have a high gloss. But $P$. nitidum has a greater altitude, a more curved ventral margin; the anterior cusps are more distal and not as sharp on top.

Specimens of $P$. nitidum form contortum may have the juncture of the anterior end with the ventral margin much as in $P$. milium, and the ventral margin straight. But $P$. $n$. 
form contortum is usually heavier; the anterior end is steeper and begins at, not above, the cusps; , the shell has a small diameter near the ventral margin, and is high at the beaks; the dorsal margin is not a uniform curve; the anterior end extends farther beyond the cusps, and the cusps are blunt on top; the cusps of A I and P I are more distal; and C 2 is heavier than $\mathrm{C} 4$.

Habitat.-Mud or ooze bottom in creeks and rivers, but mostly in ponds and small lakes. Rather scarce with usually only a few in a habitat. Apart from one drainage area in Lennox and Addington Co., Ontario, I have collected very few specimens. It appears to be more plentiful in Europe.

Geographic Distribution.-Canada: Ontario (north to James Bay), Manitoba (Sterki), Saskatchewan, and British Columbia. UnIrrd statrs: Maine (Sterki), New York, Michigan, Minnesota (Sterki), Montana, Oregon, Utah, Colorado and Aleutian Islands. FUROIE.

\section{Pisidium nitidum Jenyns \\ (Pl. V, Fig. 6; Pl. VII, Fig: 17)}

1832, Pisidium nitidum Jenyns.

1865, Pisidium contortum Prime.

1896d, Pisidium pauperculum Sterki.

1898a, Pisidium splendidulum Sterki.

1899b, Pisidium handwerki Sterki.

1901a, Pisidium tenuissimum Sterki. 1906d, Pisidium minusculum Sterki.

1913, Pisidium glabellum Sterki.

1913, Pisidium lermondi Sterki.

1916b, Pisidium latchfordi Sterki.

$1922 b$, Pisidium limpidum Sterki.

1922b, Pisidium prognathum Sterki

Measuriments.-UMMZ 189604. Napanee River, 3/4 mi. above Colebrook, Lennox and Addington Co., Ontario. Length: 3.0, 2.6, 2.2, 1.6. Height: 2.7, 2.2, 1.8, 1.4. Diameter: 2.0, 1.4, 1.3, 0.9. UMMZ 189639. Indian River, above Lang, Otonabee Twp., Peterborough Co., Ontario, form pauperculum. L: $2.8,2.4,2.0,1.7 ; \mathrm{H}: 2.6,2.2,1.8,1.6 ; \mathrm{D}: 1.8,1.6,1.3,1.0$.

Forms.-In addition to the typical species, two ecological forms are recognized: $P$. nitidum form pauperculum and $P$. nitidum form contortum.

Diagnostic Characters.-Shell moderately small, walls thin, rhomboid, of small diameter; beaks subcentral, broad, not very prominent; periostracum glossy; striae moderately fine, uniform and distinct (in some lots quite prominent), heavy striae around beaks not as common in North American specimens as in European; dorsal margin long, evenly curved, joins ends without angle; ventral margin more gently curved; anterior end with a rounded slope joining ventral margin low in a rounded point; posterior end vertical or undercut, joining ventral margin imperceptibly; hinge long, of moderate width and somewhat curved; laterals of moderate length, straight or flaring outward at distal end; cusps rather prominent, but inclined to be blunt on top; cusp of A I distal or on distal side of center, of P I, P II, and A II rather distal; cardinals subcentral; C 3 gently curved, of uniform width except at posterior end, and almost parallel with hinge-plate; C 2 slightly heavier than C 4; C 4 straight or gently curved, about parallel with C 2, space between the two of uniform width, straight or a little curved, and usually directed across hinge-plate at a gentle angle. The cardinals of $P$. nitidum are much as in $P$. subtruncatum but shorter.

The ecological form $P$. nitidum form pauperculum is rather short, high, heavy, with dorsal margin much curved; beaks sometimes more prominent than in the typical form: anterior end steep below the cusps; hinge-plate and teeth heavier; the cardinals morc nearly central. 
Comparisons.-Some $P$. nitidum form pauperculum might be mistaken for a small form of $P$. variabile. But the form pauperculum is much smaller, its anterior end steep (the steepness beginning low, at center of cusp or lower), C 3 only slightly curved, posterior end of C 2 comes nearer C 4 making these two more nearly parallel, cusp of A II is more distal; the nepionic shell is short, not long as in $P$. variabile. The very young specimens of variabile are much different.

For comparisons with $P$. aequilaterale, $P$. ferrugineum, $P$. milium, and $P$. variabile see appropriate sections under these species.

HaвiтAт.-Large ponds, bog ponds, lakes, creeks, and rivers. Seems to prefer shallow water; fairly common.

Geographic Distribution.-Canada: Newfoundland, Cape Breton Island, Magdalen Island, Prince Edward Island, New Brunswick, Quebec, Ontario, Manitoba, Saskatchewan, Alberta, British Columbia, and Northwest Territories. united states: Maine, Vermont, Massachusetts, Rhode Island, New York, New Jersey, Pennsylvania, District of Columbia, Virginia, Ohio, Michigan, Indiana, Wisconsin, Illinois, Minnesota, North Dakota, Iowa, Texas, Montana, Washington, California, Nevada, Utah, Colorado, Arizona, and New Mexico. Mexico. eurasia. AFrica: Egypt.

Fossils of $P$. nitidum of Early Pliocene origin (Laverne formation) have been reported from Beaver Co., Oklahoma, U.S.A. Further records exist from Early Pleistocene times onwards in the High Plains region.

\section{Pisidium obtusale Pfeiffer}

(Pl. IV, Fig. 4; P1. VII, Fig. 10)

1821, Pisidium obtusale Pfeiffer.

1851, Pisidium ventricosum Prime.

1851, Pisidium rotundatum Prime.
1865, Pisidium ventricosum Prime.

1865, Pisidium rotundatum Prime.

1896 , Pisidium vesiculare Sterki.

Forms.-In addition to Pisidium obtusale s.s (the European form) two forms are recognized within the species: $P$. obtusale form rotundatum and $P$. obtusale form ventricosum.

Measurements.-Pond in creek, Lennox and Addington Co., Ontario. Form rotundatum. Length. 2.7, 2.4, 1.7, 1.4. Height: 2.4, 2.1, 1.4, 1.1. Diameter: 2.0, 1.6, 1.0, 0.7. Hughes Lake, Lennox and Addington Co., Ontario. Form ventricosum. I.: 1.7, 1.7, 1.5, 1.2; $\mathrm{H}$ : $1.7,1.6,1.2,1.1 ; \mathrm{D}: 2.1,1.7,1.2,0.7$.

Diagnostic Cinaracters. $-P$. obtusale form rotundatum differs from the typical $P$. obtusale of Europe in being shorter, more inflated, having the beaks farther back, and in being higher at the beaks in comparison with the anterior end. However, I have numerous specimens from Europe that correspond with these North American specimens. $P$. obtusale form ventricosum has a heavy hinge and the beaks are very far back. My state. ments below concern $P$. obtusale form rotundatum.

Shell very small, walls thin, more or less oval in outline, well inflated; striae moderate to very fine, evenly spaced; periostracum glossy; beaks rather prominent and well posterior; dorsal margin short and well rounded; ventral margin long and more openly rounded; posterior end well rounded and vertical; anterior end descending rather low, round, shell without an angle; hinge very short, far back but almost parallel with ventral margin; hinge-plate narrow; laterals short; cusps short and high with near-vertical ends; cusps of A II proximal, of P II and A I central or on distal side of center; cardinals close 
to anterior cusps; C 3 curved, but not much enlarged at posterior end (in $P$. $o$. form ventricosum it is much enlarged); $\mathrm{C} 2$ and $\mathrm{C} 4$ short; C 2 almost parallel with hingeplate, straight, sometimes slightly curved, or just a peg; C 4 straight or slightly curved, sometimes parallel with hinge-plate, but more often directed slightly downward, then not parallel with C 2; proximal end of posterior sulcus of right valve closed by a pseudocallus on inner side of proximal end of P III and, therefore, does not run out on top of hingeplate.

$P$. obtusale form ventricosum looks like a $P$. obtusale form rotundatum with a heavier hinge-plate, and with the ventral margin pushed forward, making the posterior end not vertical but undercut. What Sterki called $P$. vesiculare is found in specimens in which the process is not carried as far. $P$. obtusale form ventricosum sometimes has a slight angle at the anterior end, and some specimens are greatly inflated.

Comparisons.-See $P$. ferrugineum.

Habitat--The form rotundatum is found in sheltered spots in lakes, creeks, and rivers, but is most commonly found in ponds and lagoons; it usually takes shelter among dead leaves of trees. The form ventricosum is found principally in lakes and large rivers.

Geographic Distribution.-Canada: Quebec, Ontario, Manitoba (Sterki), Saskatchewan, Alberta, and Northwest Territories. united states: Maine, Massachusetts, New York, New Jersey, Ohio, Michigan, Illinois, Minnesota, Montana, Washington, California, Utah, North Dakota, South Dakota, and Colorado. MExico. Eurasia (Ireland to Japan).

The earliest fossil records are from Middle Plcistocene deposits (Cudahy and Berends faunas) in southwestern Kansas and Oklahoma, U.S.A.

\section{Pisidium punctiferum (Guppy) \\ (Pl. VI, Fig. 2; Pl. VII, Fig. 19)}

1867, Cyclas punctifera Guppy.

1895b, Pisidium punctatum Sterki. 1898a, Pisidium singleyi Sterki. 1905a, Pisidium limatulum Sterki. $1911 b$, Pisidium inornatum Sterki. 1918, Pididium tenuilineatum Stelfox.

There is some question about the specific validity of $P$. tenuilineatum. Two Europcan authorities agrec that it is a valid species; two say it is not.

Measurimentrs.-UMMZ 200801. Bon Echo Creek, Barric Iwp., Frontenac (co., Ontario. Length: 2.2, 2.0, 1.8, 1.7. Height: 1.8, 1.7, 1.6, 1.3. Diameter: 1.2, 1.2, 1.0, 1.0. UMMZ 198653. Drift, Rio Culiacán, Sinaloa, México. L: 2.4, 2.0, 1.7, 1.3; H: 2.1, 1.7, 1.3, 1.1; I): $1.7,1.1,0.8,0.6$.

Diagnostic Charactirs.-Shell small with fairly thick wall, varying somewhat in shortness and height; beaks varying in prominence, subcentral to somewhat farthcr back; striac faint to rather prominent, uniformly spaced; periostracum dull; dorsal margin rounded, in large specimens more steeply and roundly curved; in some specimens there are angles wherc it joins the ends; ventral margin well rounded; anterior end has a slope more or less rounded and differing in degree of stcepness, ending in a rounded point; posterior end roundly truncate, vertical; hingc fairly long, moderately to considerably curved; hinge-plate in some specimens very narrow at cardinals, of moderate breadth and length; laterals rather long, with distinct cusps, of moderate height, but not very sharp; cusp of A I fairly distal or on distal side of center, of P I distal or on distal side of center, of A II about central or on distal side of center, of P II distal; cardinals subcentral; C 2 short, of moderate wiclth, parallel with hinge-plate, or almost so; C 4 a little longer than 
C 2, straight or slightly curved, and, beginning above center of C 2, directed toward or slightly inside or outside the cusp of P II; C 3 straight or slightly curved and about parallel with hinge-plate, enlarged posterior cnd frequently overhanging inside of hinge-plate.

This species varies greatly. The specimens from Europe usually have a longer anterior slope. There is a tendency for northern specimens from both Canada and Europe to show heavier striae than southern ones, but some southern specimens show a considerable dcgree of striation, and some Canadian specimens are rather finely striated. A few specimens have incipient ridges on the beaks. Some southern specimens attain a rather largc sizc. In some specimens that have a heavy hinge the laterals are heavier and appear to bc shorter. But, in spite of the variation, the hinge characters are constant, the anterior end slopes, and the specimens are small. They impress me as all belonging to one species; I cannot clearly separate them. Nils $\mathrm{Hj}$. Odhner, Stockholm, after examining the animals of some specimens of $P$. punctatum that I sent him, concluded that they were the samc species as $P$. tenuilineatum.

Comparisons.-See $P$. conventus and $P$. insigne.

Habitat.-Creeks (the more angular form), lakes, and rivers. It has been collected from the St. Lawrence River at a depth of 34 feet.

Geographic Distribution.-Ganada: Ontario. united states: Massachusetts, Pennsylvania, Virginia, Mississippi, Alabama, Florida, Ohio, Michigan, Indiana (Sterki), Illinois (Sterki), Wisconsin, Texas, and Arizona. méxico. Central and south america: Guatemala, Uruguay, and West Indies (including Trinidad). EURope.

What appcars to be an early form of this species was recovered by the U.S. Geological Survey from the Latc Pliocenc of Utah and Idaho.

\section{Pisidium subtruncatum Malm}

(Pl. VI, Fig. 1; Pl. VII, Fig. 18)

1855, Pisidium subtruncatum Malm. 1909c, Pisidium marci Sterki.
1913, Pisidium overi Sterki. $1922 b$, Pisidium apiculatum Stcrki.

Mrasurfiments.-UMMZ 192442. Stoco Lake, Hungerford Twp., Hastings Co., Ontario. Length: $3.4,2.9,2.4,1.8$. Height: $2.8,2.4,2.0,1.5$. Diameter: 1.8, 1.7, 1.3, 0.9 .

Diagnostic Ciharacitrs.-Shell varying in size from rather small to medium; walls thin; long to rather short; periostracum usually glossy; striac moderately finc and evenly spaced; beaks narrow, prominent and far back, tilted back and not blending quickly into body of shell; dorsal margin short, not parallel with ventral margin but far back, joining anterior cnd above, or at, anterior cusps with an angle, also joining posterior end with angle; anterior end usually long (but in short specimens it is short and stecp) with long, almost straight slope, beginning above or at anterior cusps and joining ventral margin in low rounded point; posterior end roundly truncate, passing into ventral margin without angle; ventral margin gently rounded; hinge short and openly rounded; hinge-plate narrow; laterals rather long, cusps prominent; cusps of A I and A II proximal to central, of P I and P II central; cardinals near anterior cusps or subcentral; C 2 and C 4 roughly parallel, posterior ends slightly nearer inner edge of hinge-plate; C 3 long and not much curved; width of hinge-plate and size of shell influences cardinals considerably.

A North American form of P. subtruncatum in the western part of the United States 
and in Canada north to Great Slave Lake, Northwest Territories (which I have been calling a "western form"), has considerable resemblance to P. lilljeborgi.

Comparisons. $-P$. subtruncatum resembles $P$. walkeri in its tilted hinge and its long, straight anterior slope. But $P$. walkeri has a silky, not glossy, periostracum; the cusp of A I is not so proximal and the cardinals of the left valve are not parallel, but, as in $P$. casertanum, C 2 is more like an inverted D. $P$. walkeri is flatter in appearance than is $P$. subtruncatum.

For comparisons with $P$. casertanum, $P$. henslowanum, and $P$. lilljeborgi see the sections dealing with those species.

Habitat.-Streams, bays, and lakes, including the Great Lakes. In Europe they arc abundant, but on this continent there are only a few at a station. The "western form" is very abundant where found.

Geographic Distribution.-Canada: Ontario, Manitoba, Saskatchewan, Alberta, British Columbia, and Northwest Territories (north to Great Slave Lake). United stATEs: New York, Ohio, Michigan, Wisconsin (Baker, 1928a: 429), South Dakota, Montana, Wyoming, California, and Colorado. EUROPE.

$P$. substruncatum is known from Late Pleistocene deposits of Wisconsin age (Vanhem formation, Jones Sink fauna), Meade Co., Kansas, U.S.A.

\section{Pisidium ultramontanum Prime}

(Pl. V, Fig. 3; Pl. VII, Fig. 15)

1865, Pisidium ultranontanum Prime.

Measurements.-UMMZ 198837. Shore drift, Eagle Lake, Lasser Co., California. Length: 5.9, 4.7, 3.6, 2.1. Height: 5.6, 4.3, 3.2, 1.8. Diameter: 3.3, 2.5, 1.9, 1.1 .

Dingnostic Characters.-This species varies considerably. The shell is about medium in size, moderately heavy, somewhat oval, and of small diameter; beaks subcentral, low and rather sharp on top; periostracum dull; striae moderately fine, but beginning at the beaks in many specimens there are two or more very coarse striae or ribs interspersed irregularly among the fine striae. If there were only one on each beak it would be called a "ridge" on the beaks (as in $P$. compressum and some others), but when this striation occurs, there are usually two or more ridges and sometimes they cover most of the shell. The dorsal margin is very short and steeply curved; the anterior end a long curve, sometimes becoming a moderately steep slope at the cusps (or slightly above or below) and joining the ventral margin without an angle or with a slight and rather low angle; posterior end rounded or truncate and inclined to swing outward; ventral margin very long and well rounded, joining posterior end without an angle; hinge long, hinge-plate broad; cusps rather low and blunt on top; cusps of A I, P I, and P II distal or on distal side of center, of A II central or on distal side of center; cardinals central or slightly nearer anterior cusps; C 2 in the shape of a peg or an inverted D; C 4 curves toward inside of shell; C 3 rather steeply curved or bent, with posterior end much enlarged.

Prime made no mention of ridges on the beaks or over the shell. More than half of my specimens are without these coarser striae or ridges. Somc of the specimens in Prime's collection at the Museum of Comparative Zoology also have these coarse striae.

Comparisons.-See $P$. compressum.

Grographic Distribution.-united states: Known only from a few localities in northernmost California and southwestern Oregon. 
Further details may be found in Taylor (1960b). As far as known he collected the first living specimens. P. ultramontanum appears to be a relict species. Fossil shells were found by the U.S. Geological Survey in Lower Pliocene and later deposits east of its present restricted distribution, as far as southern Idaho.

\section{Pisidium variabile Prime \\ (Pl. III, Fig. 4; Pl. VII, Fig. 4)}

1851, Pisidium variabile Prime.

1853, Pisidium cicer Prime.

1865, Pisidium compressum cicer Prime.

1865, Pisidium variabile Prime. 1916b, Pisidium variabile cicer Sterki.

1922, Pisidium decisum Sterki.

1923, Pisidium probum Sterki.

Measurements.-UMMZ 187738. In creek, Hughes Lake, Denbigh Twp., Lemnox and Addington Co., Ontario. Length: 4.6, 3.8, 3.0, 1.8. Height: 3.9, 3.2, 2.4, 1.4. Diameter: 2.8, $2.3,1.7,0.9$.

Diagnostic Characters.-Shell heavy, varying from short and high to moderatcly long; beaks rather prominent, quite far back and broad; striae rather coarse to rather fine; periostracum glossy; dorsal margin short and round; anterior end begins near beaks without angle, has a rather steep, almost straight slope which begins near the proximal side of cusps and descends to where it joins ventral margin with an angle; ventral margin long (in the longer specimens three times that of the dorsal margin) and considerably curved, passing into posterior end without angle; posterior end broadly rounded, vertical or slightly undercut; hinge long, heavy and rather steeply curved; laterals rather short, incorporated into hinge-plate; A III and P III tend to curve around pit of sulcus; cusps blunt on top; cusps of A I distal, of P I, A II, and P II central or on distal side of centcr; cardinals central; C 3 short, much curved, posterior end much the larger; $\mathrm{C} 2$ short and stout like an inverted D; C 4 fairly short, only slightly curved and directed toward cusp of P II; considerable space between posterior ends of C 2 and C 4 .

Comparisons.-See sections dealing with $P$. aequilaterale, $P$. casertanum ponderosum, $P$. compressum and $P$. nitidum form pauperculum.

HАвгтАт.-Creeks, rivers, and lakes; usually in still water where soft sceliments accumulate.

Geographic Distribution.-Canada: Prince Edward Island, New Brunswick, Quebec, Ontario (north to James Bay), Saskatchewan, and British Columbia. UnITrd sTatrs: Maine, Vermont, Massachusetts, Rhode Island, Connecticut, New York, New Jersey, Pennsylvania, District of Columbia, Tennessee, Alabama, Ohio, Michigan, Indiana, Wisconsin, Illinois, South Dakota, Iowa, Montana, Washington, Idaho, California, Utah, and Colorado. 


\section{Pisidium walkeri Sterki}

(Pl. III, Fig. 6; Pl. VI, Fig. 4; Pl. VII, Fig. 6)

1895c, Pisidium walkeri Sterki.

1903, Pisidium mainense Sterki.

Measurements.-UMMZ 194908. Stoco Lake, Hungerford Twp., Hastings Co., Ontario. Length: $5.9,3.7,3.0$, 2.1. Height: 4.9, 3.0, 2.4, 1.7. Diameter: 3.6, 2.0, 1.4, 1.0. UMMZ 187161. Dry Lake, Marlbank, Hastings Co., Ontario. Form mainense. L: 3.1, 2.6, 2.1, 1.7; $\mathrm{H}: 2.5,2.2,1.7,1.4 ; \mathrm{D}: 1.7,1.5,1.2,0.8$.

Diagnostic Characters.-Shell of medium size, long, moderate diameter, thin walls; beaks far back, rather prominent, narrow; striae medium to somewhat heavy, uniformly spaced; periostracum dull to slightly silky; dorsal margin tilted back, short, openly curved, joining anterior end with small angle and posterior end with greater angle; anterior end a long, slightly curved slope, joining ventral margin quite low with rounded angle; ventral margin very long and not much curved, joining posterior end without angle; posterior end vertical; hinge rather short, light, far back, tilted (not parallel with ventral margin); laterals rather long; cusps moderately sharp; cusps of A I central or on distal side of center; of P I distal, of A II proximal or on proximal side of center, of P II central; cardinals subcentral; C: 2 short, much curved (sometimes an inverted D); C 4 much lighter, short, curved, directed toward interior of shell; C 3 parallel with hinge-plate varying in degree of curvature, its posterior end enlarged.

The form mainense is smaller with finer striae, the anterior slope a little more rounded and, usually, beginning a little nearer the beaks. The shell is relatively shorter and, therefore, appears to be higher in outline. The cardinals of the left valve are more nearly parallel (as in $P$. subtruncatum) and $\mathrm{C} 2$ is longer than in the usual $P$. walkeri s.s.

A form found in Mazinaw Lake and vicinity, Lennox and Addington Co., Ontario, is even higher for the length than the form mainense, of less diameter, and the beaks are less prominent. The striae are also finer than in the usual $P$. walkeri.

Comparisons.-See sections dealing with $P$. casertanum and $P$. subtruncatum.

HABITAT.-Creeks, rivers, and small lakes. Scarce and usually not abundant in any one place. $P$. walkeri form mainense is found in bodies of water having a soft bottom. From the 19 stations that had yielded the specimens of the form mainense in my collection, 17 were small lakes or ponds; there was one creek and one small river. It is found in relatively few places, but is abundant in some small lakes that are filling up with shells and marl.

Geographic Distribution.-Canada: Ontario, Saskatchewan, Alberta, and Northwest Territories (Big Buffalo River at Great Slave Lake). United stATEs: Maine, New York, Pennsylvania, Virginia (Sterki), Wisconsin (Baker, 1928a: 394), Minnesota, Michigan, Iowa, Missouri (Sterki), S. Dakota (Sterki), Montana, and Arizona.

The form mainense has been found in Canada in Alberta, Saskatchewan, and the southern part of Ontario. In the United States: Maine, Massachusetts, Rhode Island, New York, Ohio (Sterki), Michigan and Illinois (Sterki).

$P$. walkeri is known from Late Pleistocene deposits of Sangamon age (Jinglebob and Jones fauna) Meade Co., Kansas, U.S.A. 


\section{SYNONYMY}

abditum Haldeman, 1841 (Pisidium) $=$ casertanum Poli, 1791. abruptum Haldeman, 1841 (Pisidium $)=$ dubium Say, 1816. abyssorum Sterki, 1898 a (Pisidium) $=$ conventus Clessin, 1877. acuminatum Prime, 1851 (Cyclas) $=$ [Sphaerium] striatinum Lamarck, 1818. affine Sterki, 1901c (Pisidium) = adamsi Prime, 1851. albidum Sterki, $1911 b$ (Pisidium) $=$ casertanum Poli, 1791. alleni Sterki, 1912c (Pisidium) $=$ casertanum Poli, 1791. apiculatum Sterki, $1922 b$ (Pisidium) = subtruncatum Malm, 1855. ashmuni Sterki, $1903 b$ (Pisidium) $=$ casertanum Poli, 1791. atlanticum Sterki, $1905 b$ (Pisidium) $=$ casertanum Poli, 1791. aurea Prime, 1851 (Cyclas) $=[$ Sphaerium $]$ striatinum Lamarck, 1818. australe Sterki, 1916b (Musculium) $=$ [Sphaerium $]$ securis Prime, 1851. cicer Prime, 1853 (Pisidium) = variabile Prime, 1851. cinereum Alder, 1838 (Pisidium) $=$ casertanum Poli, 1791. columbianum Sterki, 1913 (Pisidium) $=$ casertanum Poli, 1791. complanatum Sterki, 1903c (Pisidium) = casertanum Poli, 1791. crassum Sterki, 1901 (Sphaerium) = sulcatum Lamarck, 1818. cuneiforme Sterki, 1903c (Pisidium) $=$ casertanum Poli, 1791. decisum Sterki, 1922b (Pisidium) = variabile Prime, 1851. declive Sterki, 1912a (Musculium) $=$ [Sphaerium $]$ lacustre Müller, 1774. declive Sterki, $1922 b$ (Sphaerium) = striatinum Lamarck, 1818.

deflexum Sterki, $1922 b$ (Pisidium) $=$ adamsi Prime, 1851. dentata Haldeman, 1841 (Cyclas) $=$ [Sphaerium] striatinum Lamarck, 1818. dispar Sterki, $1911 b$ (Pisidium) $=$ casertanum Poli, 1791.

elevata Haldeman, 1841 (Cyclas) $=[$ Sphaerium $]$ partumeium Say, 1822. elevatum Sterki, $1916 b$ (Pisidium) $=$ casertanum Poli, 1791. emarginata Prime, 1851 (Cyclas) $=$ [Sphaerium $]$ striatinum Lamarck, 1818. equalis Rafinesque, 1820 (Phymeroda) $=$ [Pisidium] dubium Say, 1816. fabale Sterki, $1916 b$ (Pisidium) $=$ casertanum Poli, 1791. fallax Sterki, 1930 (Sphaerium) = sulcatum Lamarck, 1818. ferrissi Sterki, 1902b (Calyculina) $=$ [Sphaerium $]$ partumeium Say, 1822. flava Prime, 1851 (Cyclas) $=$ [Sphaerium] striatinum Lamarck, 1818. friersoni Sterki, 1906d (Pisidium $)=$ casertanum Poli, 1791 furcatum Sterki, 1913 (Pisidium) $=$ casertanum Poli, 1791. glabellum Sterki, 1913 (Pisidium) $=$ nitidum Jenyns, 1832. griseolum Sterki, $1922 b$ (Pisidium) $=$ casertanum Poli, 1791. handwerki Sterki, 18996 (Pisidium) $=$ nitidum Jenyns, 1832. hannai Sterki, 1916a (Pisidium) $=$ casertanum Poli, 1791. hendersoni Sterki, 1923 (Pisidium) = conventus Clessin, 1877. hendersoni Sterki, 1906 (Sphaerium) = striatinum Lamarck, 1818. hibernicum Westerlund, 1894 (Fossarina $)=[$ Pisidium $]$ ferrugineum Prime, 1851 . hodgsoni Sterki, 1902b (Calyculina) $=[$ Sphaerium $]$ partumeium Say, 1822. huachucanum Sterki, $1916 b$ (Pisidium) $=$ casertanum Poli, 1791. inornatum Sterki, $1911 b$ (Pisidium) = punctiferum Guppy, 1867. jalapense Pilsbry, 1903 (Sphaerium) $=$ striatinum Lamarck, 1818. jayensis Prime, 1851 (Cyclas) $=$ [Sphaerium] lacustre Müller, 1774. kirklandi Sterki, 1899a (Pisidium) $=$ fallax Sterki, $1896 c$. 
latchfordi Sterki, $1916 b$ (Pisidium) $=$ nitidum Jenyns, 1832.

lenticula Prime, 1865 (Sphaerium) = lacustre Müller, 1774.

lermondi Sterki, 1913 (Pisidium) $=$ nitidum Jenyns, 1832.

lilycashense Baker, 1898 (Sphaerium) = striatinum Lamarck, 1818.

limatulum Sterki, $1905 a$ (Pisidium) = punctiferum Guppy, 1867.

limpidum Sterki, $1922 b$ (Pisidium) $=$ nitidum Jenyns, 1832.

lineatum Sterki, 1901a (Sphaerium) = sulcatum Lamarck, 1818.

lucidum Sterki, 1923 (Pisidium) $=$ casertanum Poli, 1791.

mainense Sterki, 1903 (Pisidium) $=$ walkeri Sterki, 1895c.

marci Sterki, 1909 (Pisidium) = subtruncatum Malm, 1855.

medianum Sterki, 1899a (Pisidium) $=$ ferrugineum Prime, 1851 .

minor Adams, 1841 (Cyclas) $=[$ Pisidium $]$ casertanum Poli, 1791.

minusculum Sterki, 1906d (Pisidium) $=$ nitidum Jenyns, 1832.

mirum Sterki, 1923 (Pisidium) = casertanum Poli, 1791.

modesta Prime, 1851 (Cyclas) $=[$ Sphaerium $]$ striatinum Lamarck, 1818.

neglectum Sterki, $1906 b$ (Pisidium $)=$ casertanum Poli, 1791.

nevadense Sterki, 1913 (Pisidium) $=$ casertanum Poli, 1791.

nobile Gould, 1855 (Sphaerium) = patella Gould, 1850.

notatum Sterki, 1927 (Sphaerium) = striatinum Lamarck, 1818.

noveboracense Prime, 1853 (Pisidium) $=$ casertanum Poli, 1791.

occidentale Newcomb, 1865 (Pisidium) = casertanum Poli, 1791.

ohioense Sterki, 1913 (Sphaerium) = striatinum Lamarck, 1818.

orbiculare Sterki, 1913 (Musculium) $=[$ Sphaerium $]$ partumeium Say, 1822.

orcasense Sterki, $1922 b$ (Pisidium) $=$ casertanum Poli, 1791.

overi Sterki, 1913 (Pisidium) $=$ subtruncatum Malm, 1855.

ovum Sterki, 1916b (Pisidium) $=$ casertanum Poli, 1791.

pallidium Gray, 1856 (Sphaerium) = transversum Say, 1829.

paradoxum Sterki, $1922 b$ (Pisidium) $=$ casertanum Poli, 1791.

paroum Sterki, 1909c (Sphaerium) = securis Prime, 1851.

pauperculum Sterki, 1896d (Pisidium) = nitidum Jenyns, 1832.

pilsbryanum Sterki, 1909a (Sphaerium) = striatinum Lamarck, 1818.

politum Sterki, 1895c (Pisidium) = casertanum Poli, 1791.

primeanum Clessin, 1878 (Sphaerium) = patella Gould, 1850.

probum Sterki, 1923 (Pisidium) = variabile Prime, 1851.

prognathum Sterki, $1922 b$ (Pisidium) = nitidum Jenyns, 1832.

proximum Sterki, 1906b (Pisidium) $=$ casertanum Poli, 1791.

punctatum Sterki, 1895 b (Pisidium) = punctiferum Guppy, 1867.

pusillum Sterki, 1910c (Musculium) $=$ [Sphaerium] lacustre Müller, 1774.

randolphi Roper, 1896a (Pisidium) = casertanum Poli, 1791.

raymondi Cooper, 1892 (Sphaerium) = lacustre Müller, 1774.

regulare Prime, 1851 (Pisidium) $=$ casertanum Poli, 1791.

roperi Sterki, $1898 b$ (Pisidium $)=$ casertanum Poli, 1791.

rosacea Prime, 1851 (Cyclas) $=$ [Sphaerium] lacustre Müller, 1774.

roseum Scholtz, 1843 (Pisidium) $=$ casertanum Poli, 1791.

rotundatum Prime, 1851 (Pisidium) = obtusale Pfeiffer, 1821.

rowelli Sterki, 1903 c $($ Pisidium $)=$ casertanum Poli, 1791.

ryckholti Normand, 1844 (Cyclas) $=[$ Sphaerium $]$ lacustre Müller, 1774.

sargenti Sterki, 1901c (Pisidium) =adamsi Prime, 1851.

scutellatum Sterki, 1896d (Pisidium) = lilljeborgi Clessin, 1886. 
similis Say, 1816 (Cyclas) $=[$ Sphaerium $]$ sulcatum Lamarck, 1818. singleyi Sterki, 1898a (Pisidium) = punctiferum Guppy, 1867.

solidula Prime, 1851 (Cyclas) $=[$ Sphaerium] striatinum Lamarck, 1818. sphaerica Anthony, 1853 (Cyclas) $=[$ Sphaerium $]$ securis Prime, 1851. sphaericum Sterki, 1912c (Pisidium) = adamsi Prime, 1851. splendidulum Sterki, 1898a (Pisidium) = nitidum Jenyns, 1832. spokani Baird, 1863 (Sphaerium) = striatinum Lamarck, 1818. staminea Conrad, 1834 (Cyclas) $=[$ Sphaerium $]$ striatinum Lamarck, 1818. steenbuchi Möller, 1842 (Cyclas) $=[$ Pisidium $]$ casertanum Poli, 1791. streatori Sterki, 1901a (Pisidium) $=$ casertanum Poli, 1791. strengi Sterki, 1902a (Pisidium) = casertanum Poli, 1791. subrotundum Sterki, 1906d (Pisidium) = casertanum Poli, 1791. subtransversum Prime, 1860 b (Sphaerium $)=$ transversum Say, 1829. succineum Sterki, 1907 b (Pisidium) $=$ casertanum Poli, 1791. superius Sterki, $1907 b$ (Pisidium) $=$ casertanum Poli, 1791. tenue Prime, $1916 b \quad($ Sphaerium $)=$ nitidum Clessin, 1876. tenuilineatum Stelfox, 1918 (Pisidium) $=$ punctiferum Guppy, 1867. tenuissimum Sterki, 1901a (Pisidium) = nitidum Jenyns, 1832. torsum Sterki, 1916b (Sphaerium $)=$ striatinum Lamarck, 1818. trapezoideum Sterki, 1896a (Pisidium) = casertanum Poli, 1791. triangularis Say, 1829 (Cyclas) $=[$ Sphaerium] striatinum Lamarck, 1818. truncata Linsley, 1848 (Cyclas) $=[$ Sphaerium $]$ partumeium Say, 1822. tumidum Baird, 1863 (Sphaerium) = striatinum Lamarck, 1818. uintaense Call, 1886 (Sphaerium) = nitidum Clessin, 1876. ventricosum Prime, 1851 (Pisidium) $=$ obtusale Pfeiffer, 1821. vermontanum Prime, 1861 (Sphaerium) = striatinum Lamarck, 1818. vesiculare Sterki, $1896 c$ (Pisidium) $=$ obtusale Pfeiffer, 1821. vexum Sterki, $1916 b$ (Pisidium) = ferrugineum Prime, 1851. virginicum Prime, 1865 (Pisidium) $=$ dubium Say, 1816. virginicum Sterki, $1916 b$ (Pisidium) $=$ dubium Say, 1816. walkeri Sterki, 1901 (Sphaerium) $=$ nitidum Clessin, 1876. winkleyi Sterki, 1909c (Musculium) $=[$ Sphaerium $]$ lacustre Müller, 1774. 


\section{GLOSSARY}

ANTERIOR END: In Pisidium this is the longer end of the shell; in Sphaerium it is the shorter end. The foot of the animal is directed toward this end.

BEAKs (UMBONES): The embryonic shell around which the later shell develops. The raised part on the dorsal margin of the shell.

CALYCULATE (CAPPED): Cup-like, as the beaks when separated from the rest of the shell by being distinctly raised, as in "Musculium."

CARDInALS: The small "teeth" under the beaks. There are usually two cardinal teeth in the left valve and one in the right; sometimes this order is reversed.

COMPRISSFD: Flattened laterally; pressed together.

cusps: The elevations on the lateral teeth.

DEPRESSED: Flattened dorso-ventrally.

DIP: A downward inclination.

DISTAL: Farthest from the beaks.

DORSAL MARGIN: The upper edge of the shell; includes the hinge.

EMBRYO: The unborn young, often still in the gill pouches.

HINGE: Includes the hinge-plate, the cardinals, and the laterals.

HINGE-PLATE: That part of the hinge between the laterals.

INFLATED: Swollen; opposite of compressed.

JUveniles: This term covers all the young, from birth to less than half-grown.

laterals (LAminaE): The long "teeth" at each end of the hinge-plate.

LFFT VALVE: When a shell is placed with the hinge up and the anterior end forward, the valve on the left side is the left valve.

NEPIONIC: The young that have been born only a short time, or the very early young stage. POSTERIOR END: The shorter end in Pisidium, and the longer end in Sphaerium; also the end from which the siphons extend.

PRoximal: Nearest the beaks.

RIBS: Very heavy striae.

RIDGES (APPENDICUlAE): A wrinkle on the beaks of Pisidium forming a ridge or raised part. RIGHT VALVE: Valve on right side (see under left valve).

STRIAE: Concentric raised lines or striations which vary from very fine to very coarse; very coarse striae are often called ribs.

SUBCENTRAL: Not quite central.

sulcus: A longitudinal furrow, one on each end of the hinge-plate, usually on the right valve, serving as socket for the teeth of the other valve.

TRUNCATE: Having the end cut off rather squarely. 


\section{BIBLIOGRAPHY}

Adams, Charles Baker

1841 $a$ Catalogue of the mollusca of Middlebury, Vermont and vicinity: with observations. Amer. Jour. Sci., ser. 1, 40:266-77.

$1841 b$ Descriptions of eleven new species of New England shells. Boston Jour. Nat. Hist., 3:318-32, Pl. 3, Fig. 11.

1842 Fresh-water and land shells. In: Zadock Thompson, History of Vermont, natural, civil and statistical, in three parts. Burlington, Vermont, 1:151-69.

Adams, Charles Christopher

1892 Mollusks as Cat-fish food. Nautilus, 5:127.

Adamstone, F. B.

1923 Distribution and economic importance of mollusca in Lake Nipigon. Univ. Toronto Biol. Studies, 22:67-119.

1924 The distribution and economic importance of the bottom fauna of Lake Nipigon. Ibid., 25:35-100.

Alder, Joshua

1838 A catalogue of the land and freshwater testaceous Mollusca found in the vicinity of Newcastle-upon-Tyne, with remarks. Trans. Nat. Hist. Soc. Northumbld. Durham, 2:337-42 (p. 341).

1848 A catalogue of the mollusca of Northumberland and Durham. Trans. Tynesidc Nats'. Field Club, 1:97-209.

Allen, John A.

1911 Notes on collecting Sphaerium and Pisidium. Nautilus, 24:140-42.

ARNold, RalPH

1909 Paleontology of the Coalinga District, Fresno and King counties, California. U. S. Geol. Surv. Bull., 396:94-95.

Bailey, Albert

1891 Shells of Erie Canal. Nautilus, 5:23.

Baily, Joshua L., JR., ANd Ruth Ingersoll Baily

1951 Further observations on the mollusca of the relict lakes in the Great Basin. Ibid., 65:46-49.

BAIRD, $W$.

1863 Descriptions of some new species of shells, collected at Vancouver Island and in British Columbia by J. K. Lord, Esq., Naturalist to the British-American Boundary Commission, in the years 1858-1862. Proc. Zool. Soc. London, 1863: 66-71.

Baker, Frank Collins

1895 The geographic distribution of the mollusca. Science, 2:179-83.

1898 A new Sphaerium. Nautilus, 12:65-66.

1899 On the mollusks of Lilycash Creek, (III). Ibid., 13:30-31.

1901 The molluscan fauna of the Genesee River. Amer. Nat., 35:659-64.

1904 The molluscan fauna of the Dells of Wisconsin. Trans. Acad. Sci. St. Louis, 14:99-105.

$1905 a$ The molluscan fauna of McGregor, Iowa. Ibid., 15:249-58. 
$1905 b$ Notes on a collection of shells from Bass Lake, Indiana. Nautilus, 19:27-28.

$1906 a$ Notes on a collection of mollusks from the vicinity of Alpena, Michigan. Trans. Acad. Sci. St. Louis, 16:1-15.

$1906 b$ A catalogue of the mollusks of Illinois. Bull. Ill. State Lab., 7:53-136.

1906c A new Sphaerium from Illinois. Nautilus, 20:21.

1909 Mollusks from Kansas and Oklahoma. Ibid.,. 23:91.

$1910 a$ The ecology of the Skokie marsh area, with special reference to the mollusca. Bull. Ill. State Lab. Nat. Hist., 8:441-99.

$1910 \mathrm{~b}$ Mollusks of Unionville, Connecticut. Nautilus, 24:68.

1911 The molluscan fauna of Tomahawk Lake, with special reference to its ecology. Trans. Wis. Acad., 17 (1):232-33.

$1913 a$ Notes on Post-glacial mollusca. I. Emmet Co., Michigan. Nautilus, 27:7-8.

$1913 b$ Mollusca from Wyoming County, New York. Ibid., 27:54.

1914 Mollusks from Magician Lake, Cass and Van Buren counties, Michigan. Ibid., 28:8-10.

1915 Mollusks fiom Berrien County, Michigan. Ibid., 29:47.

$1916 a$ The relation of mollusks to fish in Oneida Lake. Tech. Publ. N. Y. State Coll. Forestry. (Syracuse Univ.), 4:1-366.

$1916 b$ The fresh-water mollusca of Oneida Lake, N. Y. Nautilus, 30:5-9.

1918 Further notes on the mollusca of Oneida Lake, New York: The mollusks of Lower South Bay. Ibid., 31:81-93.

1919 Fresh-water mollusca from Colorado and Alberta. Bull. Amer. Mus. Nat. Hist., 41:527-39.

$1920 a$ Pleistocenc mollusca from Indiana and Ohio. Jour. Geol., 28:446-52.

$1920 b$ The effect of sewage and other pollutions on animal life of rivers and streams. Trans. Ill. State Acad. Sci., 13:271-79.

1920 c Animal life and sewage in the Genesee River, New York. Amer. Nat., 54:152-61. $1920 d$ Notes on a small collection of shells from Alaska. Nautilus, 34:67-68.

$1922 a$ Pleistocene mollusca from Northwestern and Central Illinois. Jour. Geol., 30: 43-62.

$1922 b$ Pleistocene mollusca from the vicinity of Joliet, Ill. Trans. Ill. State Acad. Sci., 15:408-20.

1924 The fauna of Lake Winnebago region: a quantitative and qualitative survey with special reference to the mollusca. Trans. Wis. Acad., 21:109-46.

1926 Fresh-water mollusca from White Lake, Oakland Co., Michigan. Nautilus, 40:49-52.

1927 Molluscan associations of White Lake, Michigan: a study of a small inland lake from an ecological and systematic viewpoint. Ecology, 8:353-70. (Rev. Naut., 41:143).

$1927 b$ On the division of the Sphaeriidae into two sub-families; and the description of a new species and genus of Unionidae with descriptions of new varieties. Amer. Midland Nat., 10:220-23.

$1928 a$ The fresh water mollusca of Wisconsin. Part 2. Bull. 70, Wis. Geol. and Nat. Hist. Survey Ser., 1527:310-429.

$1928 b$ The mollusca of Chautauqua Lake, New York, with descriptions of a ncw variety of Ptychobranchus and of Helisoma. Nautilus, 42:48.

1928c Molluscan life of the Loess deposits of Illinois. Trans. Ill. State Acad. Sci., 20:273-91.

1929 A study of the Pleistocene mollusca collected in 1927 from deposits in Fulton County, Illinois. Ibid., 21:309-11. 
1930 A review of our present knowledge concerning the character and distribution of the Pleistocene aquatic molluscan life of Illinois. Ibid., 22:411-34.

1934 The molluscan fauna of the great river valleys of Illinois. Ibid., 26:129.

1935 Land and freshwater mollusca from North Star Lake and vicinity, Itasca County, Minnesota. Amer. Midland Nat., 16:268-69.

1938 New land and freshwater mollusca from the Upper Pliocene of Kansas and a new species of Gyraulus from the early Pleistocene strata. Nautilus, 51:126-31.

1939 Land and freshwater mollusca from Western Ontario. Can. Jour. Res. D, 17:87102.

BAKER, F. C., AND A. R. CAIIN

1929 Freshwater mollusca from Central Ontario. Can. Dept. Mincs. Natl. Mus. Can., Ann. Rept., Bull. 67:46-48.

BAKER, H. B.

1921 The mollusca of Dickinson Co., Michigan. Occ. Papers, Mus. Zool. Univ. Mich., $3: 1-44$.

1930 The mollusca collected by the University of Michigan-Williamson Expedition in Venezuela. Ibid., 210:52-59.

Baudon, A.

1857 Essai monographique sur les pisidies Françaises. Mém. Soc. Acad. Oise, Beauvais, $3: 315-67,5$ pls.

BeEtle, Dorothy E.

1957 The mollusca of 'Teton County, Wyoming. Nautilus, 71:12-13.

\section{BeLl, Robert}

1861 On the occurrence of freshwater shells in some of our Post-Tertiary deposits. Can. Nat., 6:42-51.

BERNARD, FÉLIX

1895-1897 Première (-Quatrième) note sur le développement et la morphologie de la coquille chez les Lamellibranches. Bull. Soc. Géol. France, Ser. 3, 23:104-54, 24:54-82, 412-49, 25:559-66.

Berry, Elmer G.

1931 Mollusca of Lamb's Canyon, Utah. Nautilus, 44:113-14.

\section{Berry, Samuel Stillman}

1909 The known mollusca of San Bernardino Co., California. Nautilus, 23:73.

1910 Mollusks of Unity, Maine. Ibid., 24:61.

1916 Notes on the mollusca of Central Montana. Ibid., 29:124.

BøGGILD, O. B.

1930 The shell structure of the mollusks: D. Kgl. Danske Vidensk. Selsk. Skrifter, Naturvidensk. og Mathem. Afd., 9. Raekke, 2(2):233-325.

Brooks, Stanley Truman, and H. B. Herrington

1944 The Sphaeriidae, a preliminary survey. Nautilus, 57 (3):93-97.

BURCH, JOHN BAYARD

1952 A preliminary list of the mollusca of Hanover County, Virginia. Nautilus, $66: 60-63$. 
Burch, Paul Randolph, and John Thornton Wood

1955 The salamander Siren lacertina feeding on clams and snails. Copeia, no. 3:25556.

Caffrey, G. W.

1911 The molluscan fauna of Northampton Co., Pennsylvania. Copeia, no. 25:25.

\section{Call, Richard Ellsworth}

1885 a Contributions to a knowledge of the freshwater mollusca of Kansas. 1. Fresh water bivalves. Bull. Washburn Col. Lab. Nat. Hist., 1, 2:49-51.

$1885 \mathrm{~b}$ Contributions to a knowledge of the freshwater mollusca of Kansas. 4. Ibid., $4: 115-24$.

1886 On certain Recent, Quaternary, and new fresh-water Mollusca. Proc. Davenport Acad. Nat. Sci., 5:1-8, P1. 1.

1887 Sixth contribution to a knowledge of the freshwater mollusks of Kansas. Bull. Washburn College Lab. Nat. Hist., 2:11-25.

1900 A descriptive illustrated catalogue of the mollusca of Indiana. 24th Ann. Rept. Geol. Survey Indiana. Indianapolis. Pp.335-535, Pls. 1-76.

Chamberlain, Ralph V., and Elmer G. Berry

1929 Notes on the mollusca of southeastern Utah. Nautilus, 42:123-25.

1930 Mollusca from the Henry Mountains and some neighboring points of Utah. Bull. Univ. Utah, 21, 2: 1-7.

Clarke, W. T., Jr.

1938 List of mollusks from drift debris of Paladora Creek, Texas. Nautilus, 52: 14-15.

1939 Pleistocene mollusks from the Panhandle of Texas. Notulae Naturae, 22.

Clench, William J.

1925 A short list of land and freshwater mollusks from southeastern Texas. Nautilus, 39: 11-12.

1959 Mollusca. In: W. T. Edmondson, Ward and Whipple's Fresh-water Biology. 2nd edition. John Wiley and Sons, N.Y., 1248 pp. (pp. 1117-60).

Ciench, William J., And Ruth D. Turner

1956 Freshwater mollusks of Alabama, Georgia and Florida from the Escambia to the Suwannee River. Bull. Florida State Mus., Biol. Sci., 1 (3): 97-239.

Ca.fssin, S.

1877 Die Mollusken der Tiefenfauna unserer Alpenseen. Malak. Blätt., 24: 159-85 (pp. 181-82).

1878 Aus meiner Novitäten-Mappe. Ibid., 25: 122-29 (pp. 122-23).

1879 Die Familie der Cycladeen. Syst. Conch.-Cab., Martini und Chemnitz, neu herausgegeb. H. C. Küster, Nürnberg, 9 (3) : 1-282 (pp. 7, 59).

Cockerfill, T. D. A.

1906 The fossil mollusca of Florissant, Colorado. Bull. Amer. Mus. Nat. Hist., 22: 459-62.

Colton, Harold S.

1929 Fossil fresh water shells from Winona, Coconino County, Arizona. Nautilus, 42:93-94.

Conrad, Timothy A.

1834 Description of some new species of fresh-water shells from Alabama, Tennessee \&c. Amer. Jour. Sci. and Art, 25:338-43 (p. 342). 
CoOper, J. G.

1892 Additional notes and descriptions of new species. Proc. Calif. Acad. Sci., (2) 3:70-89.

Cristy, Robert Miller

1885 Notes on the land and freshwater mollusca of Manitoba. Jour. Conch., 4:33949.

Dall, William H.

1895 A new classification of the Pelecypoda. Wagner Free Inst. Sci., $3(3): 481-947$.

1905 Land and fresh water mollusks. Vol. 13. In: Harriman Alaska Expedition with cooperation of Washington Academy of Sciences. Doubleday, Page and Co., N.Y. 171 pp.

1919 Molluscs, Recent and Pleistocene. Report of the Canadian Arctic Expedition, 1913-1918; 8. Mollusks, echinoderms, coelenterates, etc. Part A, Ottawa, 1919.

DANCE, S. P.

1956 A new Sussex locality for Pisidium pseudosphaerium Favre. Jour Conch., $24(3): 91-92$.

DANiELS, LORENZO E.

1903 A checklist of Indian mollusca with localities. 27th Ann. Rept. Dept. Geol. and Nat. Res. Ind. 1902, Pp. 643-46.

\section{DeCamp, William $\mathrm{H}$.}

1881 List of the shell-bearing mollusca of Michigan. Kent Sci. Inst. Misc. Publ., $5: 1-15$.

Drew, Gilman A.

1896 The anatomy of Sphaerium sulcatum Lam. Proc. Iowa Acad. Sci., 3:173-82, Pls. 8-10.

Eggleton, Frank E.

1931 A limnological study of the profundal bottom fauna of certain fresh-water lakes. Ecol. Mon., 1 (3):231-331 (pp. 255, 258).

1937 Productivity of the profundal benthic zone in Lake Michigan. Papers Mich. Acad. Sci. Arts and Letters, 1936. 22:602.

ELLIS, A. E.

1940 The identification of British species of Pisidium. Proc. Malac. Soc. London 24 (2) :44-88, Pls. 3-6.

1946 Freshwater bivalves (mollusca) (Corbicula, Sphaerium, Dreissena). Synopses of the British fauna, 4: 1-15, Pls. 1-6.

1949 Nomenclature notes. Jour. Conch. 23:50-51.

1959 Proposed addition to the official list of specific names in zoology of the specific name casertanum Poli, 1791 as published in the binomen Cardium casertanum (Class Pelecypoda). Z. N. (S.) 500. Bull. Zool. Nomencl., 17 (1/2):43-44.

ESmark, FrL. B., AND Aug. Hoyer

1886 Systematisches Verzeichniss der im arctischen Faunengebiete Norwegens lebenden Binnenmollusken. Malak. Blätt., N. F. 8:98-123 (p. 119).

EYFRDAM, WALTER J.

1934 Land and freshwater shells from the vicinity of Yakima, Wash. Nautilus, 48: $46-48$. 
Favre, Jules

1940 La faune malacologique post-glaciaire et actuelle du Lac du Bourget. Ann. École Nat. Eaux Forêts Stat. Recher. exper. forest, 2:326-50.

1941 Les Pisidium du Canton de Neuchâtel. Bull. Soc. Neuchâteloise Sci. Nat., 66:57-112.

1943 Révision des espèces de Pisidium de la Collection Bourguignat du Muséum d'Histoire naturelle de Genève. Parts I and II. Rev. Suisse Zool., 50:1-64.

Feliksiak, Stanislaw

1938 Pisidium subtruncatum Malm v. tenuilineatiformis v. n. oraz kilka nowych lub rzadkich dla Polski groszkowek (Pisidium C. Pfeiffer). Fragmenta Faun. Mus. Zool. Polon., 3 (24) :485-93.

Foster, Thural Dale

1932 Observations on the life history of a fingernail shell of the genus Sphaerium. Jour. Morph., 53 (3):473-97.

Foster, Thural Dale, and William C. Van Deventer

1933 A comparative study of river, pool and pond communities, with special reference to the Sphaeriids. (abstract). Trans. Ill. State Acad. Sci., 26 (2) :132.

Franzen, Dorothea S.

1957 Types of mollusks described by F. C. Baker. Part II, Univ. Wisconsin. Nautilus, 71:34.

Frye, John C., AND A. Byron LEONARd

1952 Pleistocene Geology of Kansas. Bull. State Geol. Surv. of Kansas, 99:150-82.

GABB, W. M.

1868 Description of a new species of Pisidium from California. Amer. Jour. Conch., $4(2): 69$.

Gilmore, RALPH J.

1917 Notes on reproduction and growth in certain viviparous mussels of the family Sphaeriidae. Nautilus, 31:16-30.

Goodrich, Calvin

1932 The mollusca of Michigan. Mich. Handbook Series, Mus. Zool. Univ. Mich., no. $5,120 \mathrm{pp}$.

1933 Mollusks of Moose Factory. Nautilus, 47:7.

1939 Certain mollusks of the Ogeechee River, Georgia. Ibid., 52:129-31.

Goodrich, Calvin, and Henry van der Schalif.

1939 Aquatic mollusks of the Upper Peninsula of Michigan. Misc. Publ. Mus. Zool., Univ. Mich., 43:7-33.

Gould, A. A.

1848 Descriptions of Connecticut shells collected and named by the late Rev. J. H. Lindsley. Amer. Jour. Sci., new ser., 6:233-36, 8 figs.

1850 (Descriptions of Shells). Proc. Boston Soc. Nat. Hist., 3:292-96.

1855 Cyclas nobilis. Ibid., 5:229.

GRAY, J .E.

1856 Descriptions of new species of Sphaerium found near London. Ann. and Mag. Nat. Hist., 17 (2):465-66. 
Greger, Darling K.

1916 Pleistocene mollusca from Gallaway County, Mo. Nautilus, 30:64.

GregG, Wendell $O$.

1947 Fresh water mollusca of California. Min. Conch. Club So. Calif., 69:3-18; 70: $14-20$.

Guppy, R. J. LeCHMERE

1867 Description of a new freshwater bivalve found in Trinidad. Ann. and Mag. Nat. Hist., ser. 3, 19:160-61.

Haldeman, S. S.

1841 Descriptions of four species of Cyclas, three of which belong to the subgenus Pisidium. Proc. Acad. Nat. Sci. Philadelphia 1:53.

HANHAM, A. W.

1890 List of land and freshwater shells of the Hamilton District to the end of the year 1889. Rept. of the Conchological Division of the Biol. Soc. Hamilton Assn. J. and Proc. Ham. Soc., Pp. 111-20.

1899 A list of the land and freshwater shells of Manitoba. Nautilus, 13: 1-6.

Hanna, G. Dallas

1920 Pleistocene mollusks from Wallace Co., Kansas. Kansas Univ. Sci. Bull., 13: 17-19.

1923 Upper Miocene lacustrine mollusks from Sonoma County, California. Proc. Calif. Acad. Sci., 12 (3) : 35-37.

1924 Freshwater mollusks of Eagle Lake, California. Ibid., ser. 4, 13: 131-36.

Hannibal, Harold

1912 A synopsis of the Recent Tertiary freshwater mollusca of the Californian Province, based upon an ontogenetic classification. Proc. Malac. Soc. London, 10: 112-211.

Hfilman, Robert A.

1948 A preliminary report of the mollusca of Lebanon County, Pennsylvania. Proc. Penna. Acad. Sci., 22: 73-75.

1951 The mollusks of Daphin County, Pennsylvania. Nautilus, 64: 100-101.

1952 The molllusks of Berks County, Pennsylvania. Ibid., 65: 103-104.

Hfilman, Robert A., and Gordon K. Macmillan

1953 Revised list of mollusks from York County, Pennsylvania. Ibid., 66: 128-29.

HrLd, F.

1836 Aufzählung der in Bayern lebenden Mollusken. Isis, 29: 271-82.

Henderson, John B., Jr.

1907 Land and fresh-water shells of Yamassee, South Carolina. Nautilus, 21:7.

Henderson, Junius

$1929 a$ Non-marine mollusca of Oregon and Washington. Univ. Colorado Studies, 17 (2) :61-71.

$1929 b$ Some fossil fresh-water molllusca from Washington and Oregon. Nautilus, 42:119-23.

1931 The problem of the mollusca of Bear Lake and Utah Lake, Idaho-Utah. Ibid., 44:109-13. 
1936a Mollusca of Colorado, Utah, Idaho and Wyoming. Univ. Colorado Studies Suppl., 23 (2) :65-223.

$1936 b$ The non-marine mollusca of Oregon and Washington. Univ. Colorado Studies Suppl., 23 (4):251-80.

Henderson, Junius, and Hugo G. Rodeck

1934 New species of Pliocene mollusca from Eastern Oregon. Jour. Paleo., $8(3): 266$.

Heron, Gilbert Clifford

1880 On the land and freshwater shells of the Ottawa. Trans. Ottawa Field-Nat. Club, 1:36-40.

Herrington, H. B.

1944 Does Sphaerium occidentale mature in one season? Can.. Field-Nat., 58:6-7.

1945 Determining species in Pisidium by the shell. Nautilus, 59 (1): 24-26.

1948 Further proof that Sphaerium occidentale does not attain full growth in one year. Can. Field-Nat., 62:74-75.

$1950 a$ Sphaeriidae of Athabaska and Great Slave lakes, Northwestern, Canada. Ibid., $64: 25-32$.

$1950 b$ Some wrong identifications of Sphaeriidae. Nautilus, 65:115-19.

1954 Pisidium species and synonyms, North America, north of Mexico. Ibid., 67:97104; 131-38.

1957 The Sphaeriidae of Lake Nipigon. Can. Field-Nat., 71:7-8.

1958 Sphaerim nitidum and $S$. patella. Nautilus, 72:10.

1959 Remarks on Sphaeriidae. (abstract). Amer. Malac. Union Ann. Repts, 1958, Bull. no. 25:22-23.

Herrington, H. B., ANd E. J. Roscol

1953 Some Sphacriidae of Utah. Nautilus, 66:97-98.

Herrington, H. B., AND DWight W. TaYlor

1958 Pliocene and Pleistocene Sphaeriidae (Pelecypoda) from the Central United States. Occ. Papers Mus. Zool., Univ. Mich., no. 596, 28 pp.

Hibrard, Claude W., and Dwight W. Taylor

1960 Two late Pleistocene faunas from southwestern Kansas. Contrib. Mus. Paleo. Univ. Mich. $16(1): 1-223,16$ pls.

Jacor, AkThur P.

1923 On the freshwater shells of Monroe, Connecticut. Nautilus, 37:28-31.

JVNYNS, L.

1832 A monograph of the British species of Cyclas and Pisidium. Trans. Camb. Phil. Soc., 4:289-311, 3 pls.

JOHNSON, RichaRd I.

1959 The types of Corbiculidae and Sphaeriidae (Mollusca: Pelecypoda) in the Museum of Comparative Zoology, and a bio-bibliographic sketch of Temple Prime, an early specialist of the group. Bull. Mus. Comp. Zool. Harvard College, $120(4): 431-79,8$ pls.

Jones, David T.

1932 Mollusks in the vicinity of Yankton, South Dakota, Nautilus, 45: 115-18. 
KENNARD, A. S., AND B. B. WOODWARD

1926 Synonymy of the British non-marine mollusca (Recent and Post-Tertiary). British Mus. (Natural History), London, 447 pp. (pp. 300-28).

Klappenbach, Miguel, A.

1960 Über die Gattungen Byssanodonta und Eupera. Arch. Moll. 89 (4/6) : 141-43.

Krull, Wendell $\mathrm{H}$.

1936 Raising Musculium partumeium Say under laboratory conditions. Papers Mich. Acad. Sci., Arts, and Letters, 21: 635-38.

KUIPER, J. G. J.

1942 Beiträge zur ökologie der niederländischen Pisidien. Basteria, 7 (1) : 23-40.

1943 Over Inversodontie bij Cycladen. Ibid., 8: 33-41.

1944 Bijdrage tot de kennis der niet-mariene mollusken van de Provincie Zeeland. Ibid., 9: 18-29.

1947 Bijidrage tot de kennis der noetwaterweekdieren van het natuurmonument Naardermeer. Ibid., 11: 35-53.

1949 Pisidium pseudosphaerium Favre in England. Jour. Conch., 23 (2): 27-32.

1952 Pisidium georgeanum, une nouvelle espèce africaine. Basteria, 16:46-48.

1953 Description de trois nouvelles espèces de Pisidium de Madagascar. Jour. de Conch., 93:26-32.

1956 Pisidium viridarium, eine neue Art aus Ost-Afrika. Arch. Moll., 85 (1/3). 61-63.

1957 Pisidium lepus, eine neue Art aus Afrika. Ibid., 86 (1/3): 85-90.

LAMARCK, J. B. P. A. de M.

1818 Histoire naturelle des animaux sans vertèbres. Paris. 5:1-612.

LaRocQue, Aurèle

1932 Mollusca of Chilcott Lake, Quebec. Can. Field-Nat., 46:152-53.

1936 The molluscan fauna of Meach Lake, Quebec. Can. Jour. Res., D, 13:45-59.

1938 Mollusca of the Ottawa Region. (Clams, snails and slugs.) Can. Field-Nat., 52:111-15.

1953 Catalogue of the Recent mollusca of Canada. Natl. Mus. Can. Dept. Resources and Development, Natl. Parks Bur. Bull. 129 (biol. ser.), 44:99-117.

LaRocque, Aurèle, and C. D. Edwards

1954 Bear River and Aspen formations in Willow Crcek, Teton County, Wyoming. Bull. Geol. Soc. Amer., 65:323.

LATCHFORD, F. R.

1913 Preliminary list of Ottawa Sphacriidac. Ottawa Nat., 27:19-20.

1916 New Sphaeriidae. Ibid., 30:93-97.

1919 Canadian Sphaeriidae. Can. Field-Nat., 33:83-86.

1920 Canadian Sphaeriidae. Ibid., 34:30-34;69-71.

1921 Canadian Sphaeriidae. Ibid., 35:68-70.

1922 Canadian Sphaeriidae. Ibid., 36:4-6.

Lionard, Alice E.

1943 The mollusca of Meade and Clark counties, Kansas. Trans. Kansas Acad. Sci., 46:231-34.

Leonard A. Byron

1950 A Yarmouthian molluscan fauna in the midcontincnt region of the United States. Univ. Kansas Paleo. Contrib., Mollusca, 3:40-42.

1952 Illinoian and Wisconsinan molluscan faunas in Kansas. Ibid., 4:8,9,20,23. 
Leonard, A. Byron, and Dorothea S. Franzen

1944 Mollusca of the Laverne Formation (Lower Pliocene) of Beaver County, Oklahoma. Univ. Kansas Sci. Bull., 30 (2) :18.

Leonard, A. Byron, and C. Raymond Goble

1952 Mollusca of the University of Kansas Natural History Reservation. Univ. Kansas Sci. Bull., 34 (2):1045-46.

LERmond, Norman WALlace

1909 Shells of Maine: A catalogue of the land, freshwater and marine mollusca of Maine. Report Agric. Comm. (7th Ann.) 1908. Waterville, Me.

Liwis, JAMES

1856 Shellbearing species of mollusca observed in portions of Herkimer and Otsego counties, New York. Proc. Boston Soc. Nat. Hist. 6:2-4.

LINK, H. F.

1807 Beschreibung der Naturalien-Sammlung der Universität zu Rostock. Rostock, 2/3: $82-160$.

\section{Linneus, Carolus}

1758 Systema Naturae, per regna tria naturae, secundum classes, ordines, genera, species, cum characteribus, differentiis, synonymis, locis. Laurentii Salvii, Holmiae. 10th ed.

Linstey, JAMES H.

1845 Catalogue of the shells of Connecticut. Amer. Jour. Sci., ser. 1, 48 (2):271-86.

Macmillan, Gordon K.

1954 Preliminary survey of the land and fresh-water gastropods of Cape Breton Nova Scotia. Can. Proc. Nova Scotia Inst. Sci., 23 (4) : 389-403.

MALM, A. W.

1855 Om Svenska Landt- och Söttvattens Mollusker, etc. Götheborgs Kungl. Vetensk\&. Vitterh.-Samh. Handl., Ny Tidsf. iii:75-152 (p. 92).

Maury, Carlotta Joaquina

1908 An interglacial fauna found in Cayugo Valley and its relation to the Pleistocene of Toronto. Jour. Geol., 16:565-67.

1916 Freshwater shells from Central and Western New York. Nautilus, 30:29.

MAZYCK, W. G.

1913 Catalog of mollusca of South Carolina. Contrib. Charleston Mus., 2:25-26.

Migitels, J. W., and C. B. Adams

1841 Descriptions of twenty-five new species of New England shells. Proc. Boston Soc. Nat. Hist., 1:48-50.

MöltLfR, H. P. C.

1842 Index Molluscorum Groenlandiac Hafniae. 24 pp. (20).

Mörch, O. A. L.

1868 On the land and freshwater mollusca of Greenland. Amer. Jour. Conch., 4:2540.

1877 The Greenland fauna IV. Mollusca. In: Henry Rink, Danish Greenland; its people and its products. Henry S. King, London. Pp. 435-42. 
Mozley, Alan

$1926 a$ Mollusca from the Manitoba-Ontario Boundary. Nautilus, 39:121.

$1926 \mathrm{~b}$ Preliminary list of the mollusca of Jasper Park. Ibid., 40: 53-56.

1926c Some molluscs from Western Canada. Ibid., 40:56-62.

1927 Molluscs from the Lake Brereton District, Manitoba. Can. Field-Nat., 41:59-61.

1928 Post-Glacial fossil molluscs from a delta deposit at Winnipeg, Manitoba. Geol. Magazine, 65:267-70.

1931 Reports of the Jasper Park Lakes investigations, 1925-26. The mollusca of Jasper Park. Trans. Roy. Soc. Edinb., 56 (3):647-69, Pls. 1-2.

1932 Fresh water mollusca in some Jasper Park lakes. Can. Alpine Jour., 1931, 20:14858.

1933 The local and geographic distribution of some Rocky Mountain mollusca. Proc. Malac. Soc. London, 20 (4) :214-21.

1935 The fresh-water and terrestrial mollusca of Northern Asia. Trans. Roy. Soc. Edinb., 58 (3) :605-96.

1936 The statistical analysis of the distribution of pond mollusca in Western Canada. Amer. Nat., 20 (728):237-44.

MüLleR, O'Tho FRIDERICUS

1774 Vermium terrestrium et fluviatilium, seu animalium infusoriorum, helminthicorum, et testaceorum, non marinorum, succincta historia. Heineck and Faber, Havniae and Lipsiae. 2: $214+$ xxxvi (p.205).

NeWCOMB, WrSi.EY

1863 Description of new shells. Proc. Calif. Acad. Sci., 2:91.

Nicolson, H. Alineyne

1872 Contributions to a fauna Canadensis, being an account of the animals dredged in Lake Ontario in 1872. Can. Jour., new ser., 13:490-506.

Normand, N. A. J.

1844 Notice sur plusieures nouvelles espèces de Cyclades découvertes dans les environs de Valenciennes. Valenciennes, 8 pp., 1 pl.

Nutting, C. C.

1893 Report on zoological explorations on the Lower Saskatchewan River. Iowa Univ. Lab. Nat. Hist. Bull., 2:235-93.

NyLANDER, OloF O.

1895 Shells of Aroostook County, Maine. Nautilus, 8:125.

1901 Shells of the marl deposits of Aroostook Co., Maine, as compared with the living forms in the same locality. Ibid., 14:101.

1914 Freshwater shells in Moose River, Somerset Co. Maine. Ibid., 28:89.

ODHNER, NiLs HJ.

1921 On some species of Pisidium in the Swedish State Museum. Jour. Conch., $16(7): 218-23$.

$1923 a$ On the anatomical characteristics of some British pisidia. Proc. Malac. Soc. London, 16:155-61.

1923 bollusca: Pisidium conventus Clessin (P. clessini Surbeck, partim). Report of the scientific results of the Norwegian expedition to Novaya Zemlya 1921, no. 6, Soc. Arts and Sci. of Kristiania, 6 pp., 1 pl.

1929 Die Molluskenfauna des Tåkern. Sjön Tåkerns Fauna och Flora. Utgiven av K. Svenska Vetenskapsakademien, 8:39-93. 
1937 Pisidium prashadi n. sp., eine neue Hochgebirgsmuschel aus Thibet. Arch. Moll., 69 (3) :117-23.

1938 Sphaeriiden aus den Adrialändern. Ibid., 70 (5/6):226-38.

1939 Sphaeriids from the Aleutian Islands. Nautilus, 52:79-84.

1940 Über Pisidien aus Süd-Schweden. Arkiv för Zoologi, 32A (11) : 1-16, P1. 1.

1951 Swedish high mountain mollusca. The mountain fauna of the Virihaure area in Swedish Lapland. Lunds universitets Arksskrift N. F. Avd. 2., 46 (2):26-35.

PfeIfFer, C.

1821-28 Naturgeschichte Deutscher Land- und Sïsswasser-Mollusken. Weimar, 3. Abth. 4to.

Pinllips, R. A.

1915 The non-marine mollusca of South Galway. Irish Nat., pp.137-50.

Pilsbry, Henry A.

1897 New species of mollusks from Uruguay. Proc. Acad. Nat. Sci. Philadelphia (1897) :290-98 (pp. 292-93) , Pl. 6.

1903 Mexican land and freshwater mollusks. Ibid., pp. 761-89 (pp. 786-87), Pls. 53,54 .

1909 Mollusca of Southwestern States. 3. Ibid., pp. 495-516.

1910 Mollusca of the Southwestern States. 4. Ibid., pp. 44-147.

1911 Non-marine mollusca of Patagonia. Reports. Princeton Univ. Exped. to Patagonia, 1896-1899. $3(5): 513-633$.

1924 South American land and freshwater mollusks. Notes and descriptions. Proc. Acad. Nat. Sci. Philadelphia, 76:53-54.

1935 Mollusks of the fresh-water Pliocene beds of the Kettleman Hills and neighboring oil fields, California. Lbid., 86:545-46.

1946 Two misunderstood Sphaeriidae. Nautilus, 59 (3):83-87.

Pilsbry, H. A., And J. H. Freriss

1906 Mollusca of the southwestern States. 2. Proc. Acad. Nat. Sci. Philadelphia, $58: 173$

Pilsrby, H. A., and Axel A. Olsson

1935 New mollusks from the Panamic Province. Nautilus, 49:16-19.

Pou, J. X.

1791 Testacea utriusque Siciliae, etc. Parma. 1:65.

Prashad, B.

1925 Notes on Lamellibranchs in the Indian Museum. Indian species of the genus Pisidium. Records of the Indian Mus., 27 (5) :405-22.

1933 Notes on Lamellibranchs in the Indian Museum. Ibid., 35 (1):1-8.

Pratt, W. H.

1871 List of the land and fresh water shells found at Davenport, Iowa. Proc. Davenport Acad. Sci., 1:165-68.

Price, Sadie F.

1900 Mollusca of Southern Kentucky. Nautilus, 14:75.

Prime, Temple

1851 Pisidium ventricosum Prime. Proc. Boston Soc. Nat. Hist., 4:68. 
$1852 a$ Descriptions of Cycladidae. Ibid., 4:155-65.

$1852 b$ Descriptions of two new species of freshwater shells. Ann. N. Y. Lyc. Nat. Hist., 5:218-19, P1. 6.

1853 Notes on the species of Cyclas found in the United States; with descriptions and wood-cuts. Proc. Boston Soc. Nat. Hist., 4:271-86.

1854 Descriptions of three new species of Pisidium. Ann. N. Y. Lyc. Nat. Hist., 6:6466.

1859 List of known species of Pisidium with their synonymy. Ibid., 7:94.

$1860 a$ Synonymy of the Cyclades, a family of acephalous Mollusca. Part I. Proc. Acad. Nat. Sci. Philadelphia (1860):267-301.

$1860 \mathrm{~b}$ Descriptions of new shells from the collection of Hugh Cuming, Esq. Proc. Zool. Soc. London, 28:319-22 (p. 322).

1861 Descriptions of new species of Cyrena, Corbicula and Spaerium. Proc. Acad. Nat. Sci. Philadelphia (1861):125-28.

$1861 b$ Monograph of the species of Sphaerium of North and South America. Ibid., Pp. 402-409.

1865 Monograph of American Corbiculadae. (Recent and Fossil). Smithsonian Misc. Coll., no. 145. Pp. $80+x$ i.

1895 Catalogue of the species of Corbiculadae in the collection of Temple Prime, now forming part of the collection of the Museum of Comparative Zoology at Cambridge, Massachusetts. Temple Prime. 62 pp.

RAFinesQue, C. S.

1820 Monographie des coquilles bivalves et fluviatiles de la rivière Ohio (contenant douze genres et soixante-huit espèces). Ann. Gen. Sci. Phys., Bruxelles, 5 (15) : 287-322.

Rawson, Donald S.

1928 Preliminary studies of the bottom fauna of Lake Simcoe, Ontario. Univ. Toronto Studies (Publ. Ont. Fish. Res. Lab. 36)., 31:75-102.

1930 Bottom fauna of Lake Simcoe and its role in the ecology of the lake. Ibid., $34: 40$.

RAwson, D. S., AND J. E. MOORE

1944 The saline lakes of Saskatchewan. Can. Jour. Res., D, 22:179.

RAYMOND, W. J.

1890 Notes on the subalpine mollusca of the Sierra Nevada, near lat. $38^{\circ}$. Proc. Calif. Acad. Sci., $3(2): 61-69$.

REFS, W. J.

1952 The role of amphibia in the dispersal of bivalve mollusks. British Jour. Herpet., $1: 7$.

Rfinder, Harald A.

1942 A list of mollusks from Intervale, N. H. Nautilus, 37:96-97.

Richards, Horace G.

1932 Molluscs from St. Joseph Island, Ontario, Canada. Can. Field-Nat., 46:33.

1934. A list of the molluscs of the District of Columbia and vicinity. Amer. Midland Nat., 15 (1):85-89.

Richardson, Robert E.

1925) Changes in the small bottom fauna of Peoria Iake, 1920-1922. Bull. Nat. Hist. Surv. Ill., 15:327-88. 
ROBERTSON, A. D.

1915 The mollusca of Georgian Bay. Contr. to Can. Biol. Suppl. to 47th Ann. Rep. Can. Dept. Marine and Fish., Pp. 95-111.

ROPER, EDWARD W.

1890 A new American Pisidium. Nautilus, 4:85.

$1896 a$ Notes on the Washington sphaeria and pisidia, with descriptions of new species. Ibid., 9:97-99.

1896b A word about sphaeria. Ibid., 10:29.

ROSCOE, ERNEST J.

1948 Some mollusca collected in the vicinity of Kanab, Kane County, Utah. Proc. Utah Acad. Sci., Arts and Letters, 24:135-36.

RusselL, LoRIS S.

1934 Pleistocene and Post-Pleistocene molluscan faunas of Southern Saskatchewan. Can. Field-Nat., 48:34-37.

SAMPSON, F. A.

1893 A preliminary list of the mollusca of Arkansas (exclusive of the Unionidae). Ann. Rept. Geol. Surv. Arkansas for 1891, 2:179-99.

SAY, T.

1816 Conchology. In: The first American edition of the British encyclopedia or dictionary of arts and sciences, comprising an accurate and popular view of the present improved state of human knowledge: by William Nicholson and C. Samuel A. Mitchell and Horace Ames, Philadelphia. Vol. 2: no pagination.

1822 Description of univalve terrestrial and fluviatile shells of the United States. Jour. Acad. Nat. Sci. Philadelphia, 2:370-81.

1829 Descriptions of some new terrestrial and fluviatile shells of North America. New-Harmony Disseminator of Useful Knowledge, New-Harmony, Indiana, 23:355-56.

\section{SCHLESCH, HaNS}

1943 Pisidium (Neopisidium) vincentianum B. B. Woodward, in altalluvialen Ablagerungen des früheren "Lerso" in Kopenhagen (Dänemark). Arch. Moll., 75 (2/3): 121-29.

Schмid, A. W. F.

1850 Malakologische Mittheilungen. Zeitschr. für Malakozool., 7:118-19.

Scopoli, J. A.

1777 J. A. Scopoli ... Introductio ad Historiam Naturalem, etc. Prague, Pp. 506 + viii.

SHEppard, J. R.

1825 Description of seven new British land and fresh-water shells, etc. Trans. Linn. Soc., 14:148-70.

\section{SHImek, BohumiL}

1921 Mollusks of the McGregor, Iowa, Region. 1. Iowa Conservation, 5 (4):81.

1935 The effect of pollution on mollusks in Iowa. Nautilus, 48:109-11.

SMith, Frank

1894 List of the protozoa and mollusca observed in Lake St. Clair in the summer 1893. In: Reighard, J. E., A biological examination of Lake St. Clair. Bull. Mich. Fish. Comm. 4: 42-44. 
Solem, Alan

1952 Some mollusks from Door Co., Wisconsin. Nautilus, 65:127-29.

SPARKS, B. W.

1955 Notes on four Quaternary deposits in the Cambridge region. Jour. Conch., 24: 47-53.

Stelfox, A. W.

1918 The Pisidium fauna on the Grand Junction Canal in Herts. and Bucks, Ibid., 15 (10):289-304, Pls. 7-9.

1922 On the Pisidium gassiesianum of Dupuy. Proc. Malac. Soc. London, 15 (1): $52-57$.

STFRKI, VICTOR

1894 The land and fresh-water mollusca in the vicinity of New Philadelphia. Beobachter Press, New Philadelphia, Ohio. $14 \mathrm{pp}$.

1895 a Some notes on Recent mollusca. 3rd Ann. Rep. Ohio State Acad. Sci., 1895: $32-37$.

$1895 b$ Two new pisidia. Nautilus, $8(9): 97-100$, P1. 2.

1895c Descriptions of new pisidia. Ibid., $9(7): 74-76$.

$1896 a$ North American pisidia. Ibid., $9(11): 124-25$.

$1896 b$ A few notes on pisidia. Ibid., 10(1):8-9.

$1896 c$ Descriptions of new pisidia. Ibid., $10(2): 20-21$.

$1896 d$ Two new pisidia. Ibid., $10(6): 64-68$.

1898 a New pisidia. Ibid., 11 (10):112-14.

$1898 b$ Descriptions of new pisidia. Ibid., 11 (11):124-26.

1898 c New pisidia. Ibid., $12(7): 77-79$.

1899a Pisidia new to our country, and new species. Ibid., 13 (1): 9-12.

$1899 b$ Pisidium handwerki, n. sp. Ibid., 13 (8):90-91.

$1900 a$ List of the land and fresh water mollusca of Tuscarawas County, Ohio. 8th Ann. Rept. Ohio State Acad. Sci., Pp. 30-42.

$1900 b$ New pisidia and some general notes. Nautilus, $14(1): 5-8$.

$1901 a$ New pisidia. Ibid., 14 (9):99-101.

$1901 b$ New North American sphaeria. Ibid., 14 (12):140-42.

$1901 c$ New pisidia. Ibid., 15 (6) :66-69.

1902 a Pisidium strengi, n. sp. Ibid., 15 (11):126.

$1902 b$ Some notes on the North American Calyculinae, with new species. Ibid., 16 (8) : 89-93.

$1902 c$ Some additions and corrections to the list of land and fresh water mollusca. Ohio Nat., 2 (8):286-87.

$1903 a$ New pisidia. Nautilus, 17 (2) :20-22.

$1903 b$ New North American pisidia. Ibid., 17 (4):42-43.

1903 c New pisidia. Ibid., 17 (7) :79-82.

$1905 a$ New species of Pisidium. Ibid., $18(9): 108$

$1905 b$ A new species of Pisidium. Ibid., 18 (11):128-29.

1905c Cycladidae of the Southern States. Ibid., 19 (3):30-32.

$1905 d$ New varieties of North American pisidia. Ibid., 19 (7) :80-84.

$1906 a$ New varieties of North American pisidia. Ibid., 19 (10):118-20.

$1906 b$ New species of Pisidium. Ibid., 20 (1):5-6.

$1906 c$ On the pathology of Sphaerium. Ibid., 20 (1):11.

1906d New species of Pisidium. Ibid., 20 (2) :17-20. 
$1906 e$ Sphaerium hendersoni, n. sp. Ibid., $20(6): 69-70$.

$1906 f$ New pisidia. Ibid., $20(8): 87-89$.

$1906 \mathrm{~g} \mathrm{~A}$ few general notes and remarks with respect to the land and fresh water Mollusca. Ohio Nat., 6:449-50.

1906/ Notes on list of Ohio Mollusca and a suggestion in regard to local lists. Ibid., 6:462.

$1907 a$ Fossil land and fresh water mollusca collected in Defiance County, Ohio. Ibid., 7 (5):110-11.

$1907 b$ New pisidia. Nautilus, $20(9): 98-100$.

1909a Sphaerium pilsbryanum, n. sp. Ibid., 22 (12) :141-42.

$1909 b$ Some observations and notes on Musculium. Ibid., 23 (2):17-19.

1909c Pisidium marci, n. sp. Ibid., 23 (3) :42-43.

1909d Descriptions of two new species of Musculium, Ibid., 23 (5):66-67.

$1910 a$ New species of Sphaeriidae. Ibid., 23 (11):142-43.

$1910 b$ A new species of Musculium. Ibid., $24(1): 3$.

$1911 a$ The cardinal teeth of Pisidium. Ibid., 25 (1):1.

$1911 b$ New pisidia from Alabama. Ibid., $25(1): 2-3$.

1912a. Musculium declive, n. sp. Ibid., 25 (9):103-104.

$1912 b$ Drift shells from Texas. Ibid., 25 (10):115-17.

$1912 c$ Sphaeriidae, old and new. Ibid., 26 (1):6-9; (8):95-96.

1913 Sphaeriidae, old and new. Ibid., 26 (10):117-19; (12):136-40.

1914 Ohio mollusca. Additions and corrections. Ohio Nat., 15 (5):270-72.

$1916 a$ A new mollusk of the genus Pisidium from Alaska, with field notes by G. Dallas Hanna. Proc. U.S. Natl. Mus., 51 (216): 475-77.

$1916 b$ A preliminary catalogue of the North American Sphacriidae. Ann. Carnegie Mus., 10 (3/4): 429-74.

$1916 c$ Some directions and suggestions for collecting the Sphaeriidae and aquatic gastropods. Ibid., $10(3 / 4): 478-86$.

1920 Marl deposits in Ohio and their fossil mollusca. Ohio Jour. Sci., 20 (6): 173-84.

$1922 a$ Some notes on the hinge of the Sphaeriidae. Nautilus, 35 (4):104-17, P1. 3.

$1922 b$ Some notes on Sphaeriidae with descriptions of new species. Ann. Carnegie Mus., 13 (3/4):425-39.

$1922 c$ Some notes on minute pisidia. Nautilus, $36(2): 39-41$.

1923 Colorado pisidia. Ibid., 37 (1):16-22, Pls. 1-3.

1926 Sphacriidac, Palearctic and Nearctic. Ibid., $40(1): 26-30$.

1927 A new species of Sphaerium (Sphaerium notatum). Ibid., 41 (2):55-57.

1928 Sphaeriidae, Palearctic and Nearctic II. Ibid., 42 (1) :23-27.

1930 Sphaerium Scopoli; Sulcastrum, new subgenus, and Sphaerium fallax, new species. Ibid., $43(3): 93-95$.

STLUSLOFF, ULRICH VON

1937 Beiträge zur Fauna and Flora des Quartärs in Mecklenburg, III. Einige Fundorte rezenter und alluvialer Pisidien in Mecklenburg. Zur Ökologie von Pisidium scholtzi. Arch. Ver. Freunde Naturgesch. Meckl. 12, 1937.

STrode, W. S.

1891 Mollusks of Spoon River, Illinois. Nautilus, 5:61.

STUPAKofF, S. H.

1894 Land and freshwater shells of Alleghany Co., Pa. Ibid., 7:135. 
TAYLOR, DWIGHT W.

1957 Pliocene fresh-water mollusks from Navajo County, Arizona. Jour. Paleo., $31(3): 656-57$.

$1960 a$ Late Cenozoic molluscan faunas from the High Plains. U.S. Geol. Survey Prof. Paper 337. 85 pp., 4 pls.

$1960 b$ Distribution of the freshwater clam Pisidium ultramontanum: a zoogeographic inquiry. Amer. Jour. Sci., 258-A:325-34, 1 pl.

Taylor, Dwight W., and Claude W. Hibbard

1955 A new Pleistocene fauna from Harper County, Oklahoma. Okla. Geol. Surv. Circ. no. 37. 23 pp.

Thiele, JohanNES

1935 Handbuch der Systematischen Weichtierkunde, Jena., 2:852-54.

Thomas, Grace J.

1954 Notes on raising sphaeriid clams in the laboratory. Turtox News, 32:10.

1959 Self-fertilization and production of young in a sphaeriid clam. Nautilus, 72 (4):131-40.

Vanatta, Edward G.

1914 Land and freshwater shells from Eastern Canada. Proc. Acad. Nat. Sci. Philadelphia, 66:222-26.

1926 Texas land and freshwater shells. Nautilus, 40:16-17.

1927 Mollusks in Sphagnum moss (from Bradford, Pa.). Ibid., 41:34.

van Benthem Jutting, W. S. S., And J. G. J. Kuiper

1942 De Lamellibranchia van bet Naardermeer. Basteria, 7:41-72.

van Cleave, Harley J., A. Gilbert Wright, and C. William Nixon

1947 Preliminary observations on reproduction in the molluscan genus Musculium. Nautilus, 61 (1):6-11.

van Der Schalie, Henry

1948 The land and fresh-water mollusks of Puerto Rico. Misc. Publ. Mus. Zool. Univ. Mich., 70:1-128.

1953 Mollusks from an interglacial deposit (Sangamon? age) in Meade Co., Kansas. Nautilus, 66:80-90.

van Regteren Altena, C. O., and J. G. J. Kuiper

1945 Pleistocene land-en Zoetwater-mollusken uit den ondergrond Van Velzen. Zoologische Mededeelingen, 25:167-99.

VAUGHaN, T. WAYLAND

1892 Mollusks of Dorcheat Bayou, Lake Bisteneau, Louisiana. Nautilus, 5:109.

WALKER, BRYANT

1895 Review of our present knowledge of the molluscan fauna of Michigan. Bryant Walker, Detroit. 27 pp.

$1896 a$ Appendix V, Report upon the mollusca collected in the vicinity of Charlevoix, Michigan, in the summer of 1894. In: A biological examination of Lake Michigan in the Traverse Bay region, by Henry B. Ward. Bull. Mich. Fish. Comm., 6:1-99 (pp. 96-99).

$1896 b$ On certain abnormal sphaeria. Nautilus, 9:135.

1898 Mollusca contemporaneous with the mastodon. Ibid., 11:121.

1899 Mollusca associated with the mastodon in Berrien Co., Mich. Ibid., 13:55. 
1900 The origin and distribution of the land and fresh-water mollusca of North America. Mich. Acad. Sci., 1st Ann. Rept.:43-61.

1903 On the shells of marls. Geol. Surv. Mich., 8 (3):97-102.

1908 Annotated list of the mollusca of Isle Royal, Michigan. Ann. Rept. Geol. Surv. Mich.: 281-98, Figs: 61-63.

1911 A check-list of the Michigan mollusca. Mich. Acad. Sci. 13th Ann. Rept.: 12129.

1916 The mollusca collected in northeastern Nevada by the Walker-Newcomb expedition of the University of Michigan. Occ. Papers Mus. Zool. Univ. Mich., 29:1-8.

1918 A synopsis of the classification of the fresh-water mollusca of North America, north of Mexico, and a catalogue of the more recently described species, with notes. Misc. Publ. Mus. Zool. Univ. Mich., 6:85-87; 188-89.

Wal.ker, Bryant, and A. C. Lane

1900 Shells of the marls of Huron County. Recent shells (of the marl). Geol. Surv. Mich., 7 (2) :247-52.

Walker, R. D., and W M. H. Collidge, JR.

1908 Mollusca of Keene, New Hampshire. Nautilus, 22:32.

WAL'TON, JOHN

1891 The mollusca of Monroe County, N.Y. Proc. Rochester Acad. Sci., 2:3-18.

1898 Mollusca of Monroe Co., N.Y. The Museum 4 (9):132-34.

Ward, Henry $B$.

1895 A biological examination of Lake Michigan in Traverse Bay Region. Bull. Mich. Fish. Comm. Appendix V, 6: 1896.

WELCH, R.

1904 Decalcification of freshwater shells. Irish Nat., 13:29.

Westerlund, C. A.

1876 Neue Binnenınollusken aus Sibirien. Nachrichtsbl. d. deutsch. malakozool. Ges. 8:97-104 (p. 102)

1886-90 Fauna der in der paläarctischen Region ... lebenden Binnenconchylien (-Supplement-Zusätze). 9 pts. (7), 8vo. Lund.

1894 Specilegium Malacologicum. Neue Binnen-Conchylien aus der Paläarctischen Region. Nachrichtsbl. d. deutsch. malakozoolog. Ges., 26:190-205.

WHEELER, H. E.

1912 The mollusca of Monte Sano, Alabama. Nautilus, 25:121.

Whiteaves, Joseph Frederick

1863 On the land and freshwater mollusca from Manitoba and the valley of the Nelson River. Geol. Surv. Can. Rept. of Progr. 1878-79, Rep. of Explorations of the Churchill and Nelson Rivers (by Robert Bell) App. 3:61-62 C.

1895 Recent mollusca from the headwaters of the Ottawa. Ottawa Nat., 9:22.

1901 Notes on some land and fresh-water mollusca from Fort Chimo, Ungava Bay, Ungava. Ibid., 14:221.

1902 Notes on some fresh-water and land shells from Keewatin, Northern Ontario and British Columbia. Ibid., 16:91.

$1905 a$ Notes on some fresh-water shells from the Yukon Territory. Nautilus, 19:1.

$1905 b$ Notes on some fresh-water shells from the Yukon Territory. Ottawa Nat., 19:63-64.

1905c Some new localities for Canadian land and fresh-water shells. Ibid., 19:169-71. 
1905d List of land and fresh water shclls from the district of Keewatin. Rept. Gcol. Surv. Can. 1905, 6.

1906a List of some fresh-water shells from Northwestern Ontario and Keewatin. Ottawa Nat., 20:29-32.

1906b Notes on some fresh water shells from British Columbia. Ibid., 20:115-16.

1907 Notes on some fresh water shells from Manitoba. Ibid., 20:239.

WHITTAKER, E. J.

1921 The fossil molluscan faunas of the marl deposits of the Ottawa District. Gcol. Surv. Can. Geol. Ser., Bull. 33:59-77.

1922 Bottom deposits of McKay Lake, Ottawa. Trans. Roy. Soc. Can., 3rd ser., 16 (4): $141-56$.

1924 Fresh water mollusca from Mackenzie River Basin, Canada. Nautilus, 38:8-12.

WINKLEY, HENRY W.

1909 Pisidium in Massachusetts. Nautilus, 22:113-14.

1914 Mollusca of Maine. Ibid., 28:48.

WinsLow, Mina L.

1917 Annotated list of shells from Northern Michigan. Occ. Papers Mus. Zool. Univ. Mich., 42:1-16.

1921 Mollusca of North Dakota. Ibid., 98:1-18.

1926 A revised check list of Michigan mollusca. Ibid., 181:24-28.

WoOD, KenNETH G.

1953 The bottom fauna of Louisa and Redrock Lakes, Algonquin Park, Ontario. Trans. Amer. Fish. Soc., 82:203-12.

WOODS, FARRIS H.

1931 History of the germ cells in Sphaerium strialinum (Lam.). Jour. Morph. Physiol., 51 (2):545-95.

WOODWARD, B. B.

1913 Catalogue of the British species of Pisidium (Recent and Fossil) in the ... British Museum (Natural History), etc. British Museum (Nat. Hist.), London. Pp. $144+$ ix.

1918 On the Pisidium nitidum and P. pusillum of Jenyns: a reply. Jour. Conch., 15:260-61.

1921 Notes on some specics of Pisidium. Proc. Malac. Soc. London, 14 (5 and 6): 209-20.

Wurtz, Cilarles B.

1949 Mollusks of the Nucltin Lake expedition, Kcewatin, 1947. Notulac Naturac, 213:1-5.

1956 Fresh-water mollusks and stream pollution. Nautilus, 69:96-100.

Yen, Teng-Chien

1944 Notes on fresh-water mollusks of Idaho formation at Hammett, Idaho. Jour. Paleo., $18(1): 108$.

1947 Pliocene fresh-water mollusks from northern Utah. Jour. Paleo., 21 (3): 268-74.

1950 A molluscan fauna from the type section of the Truckec formation. Amcr. Jour. Sci., 248: 180-93.

1950 Fresh-water mollusks of Cretaceous age from Montana and Wyoming. Geol. Surv. Prof. Paper 233-A: 1-20. 


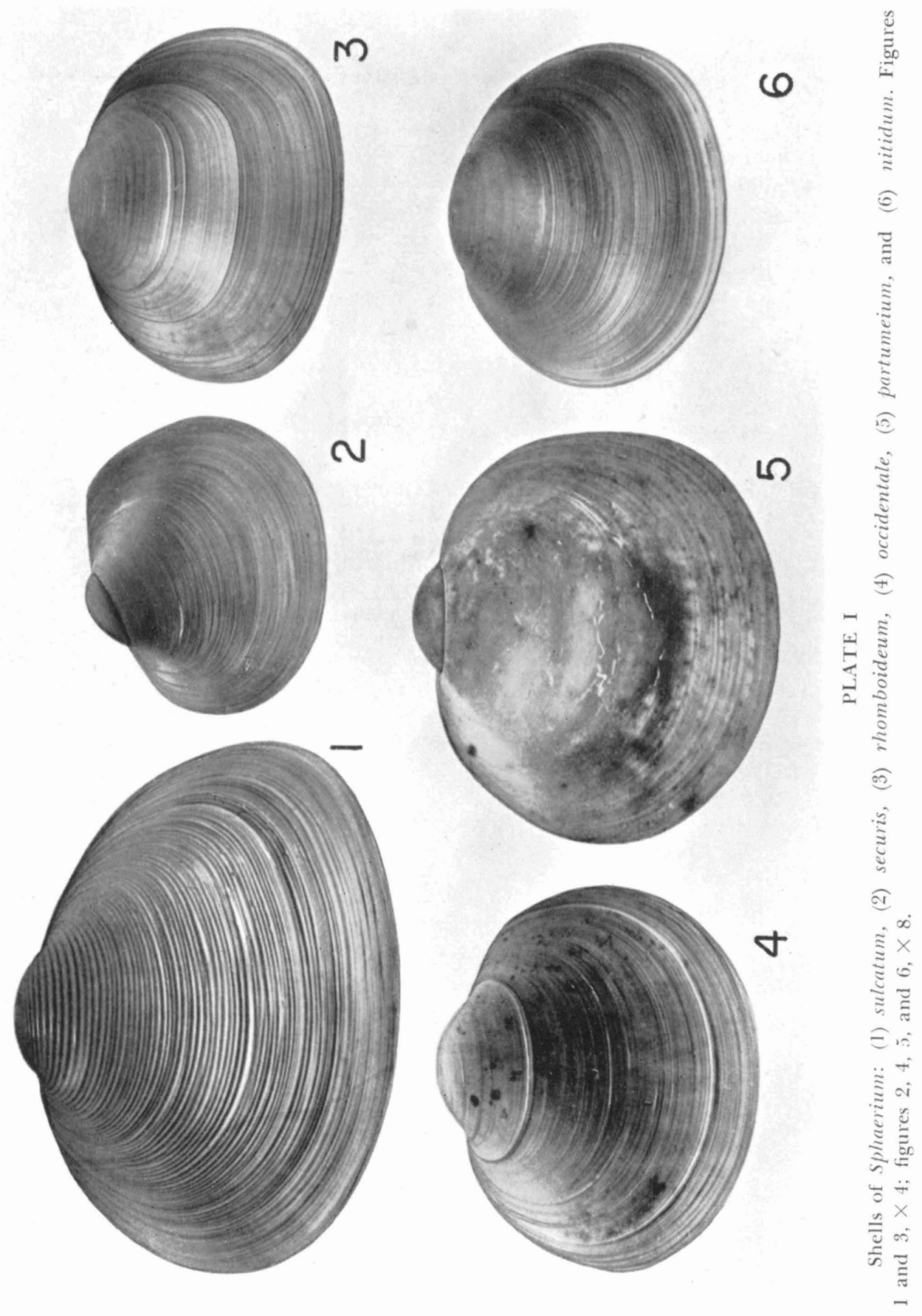




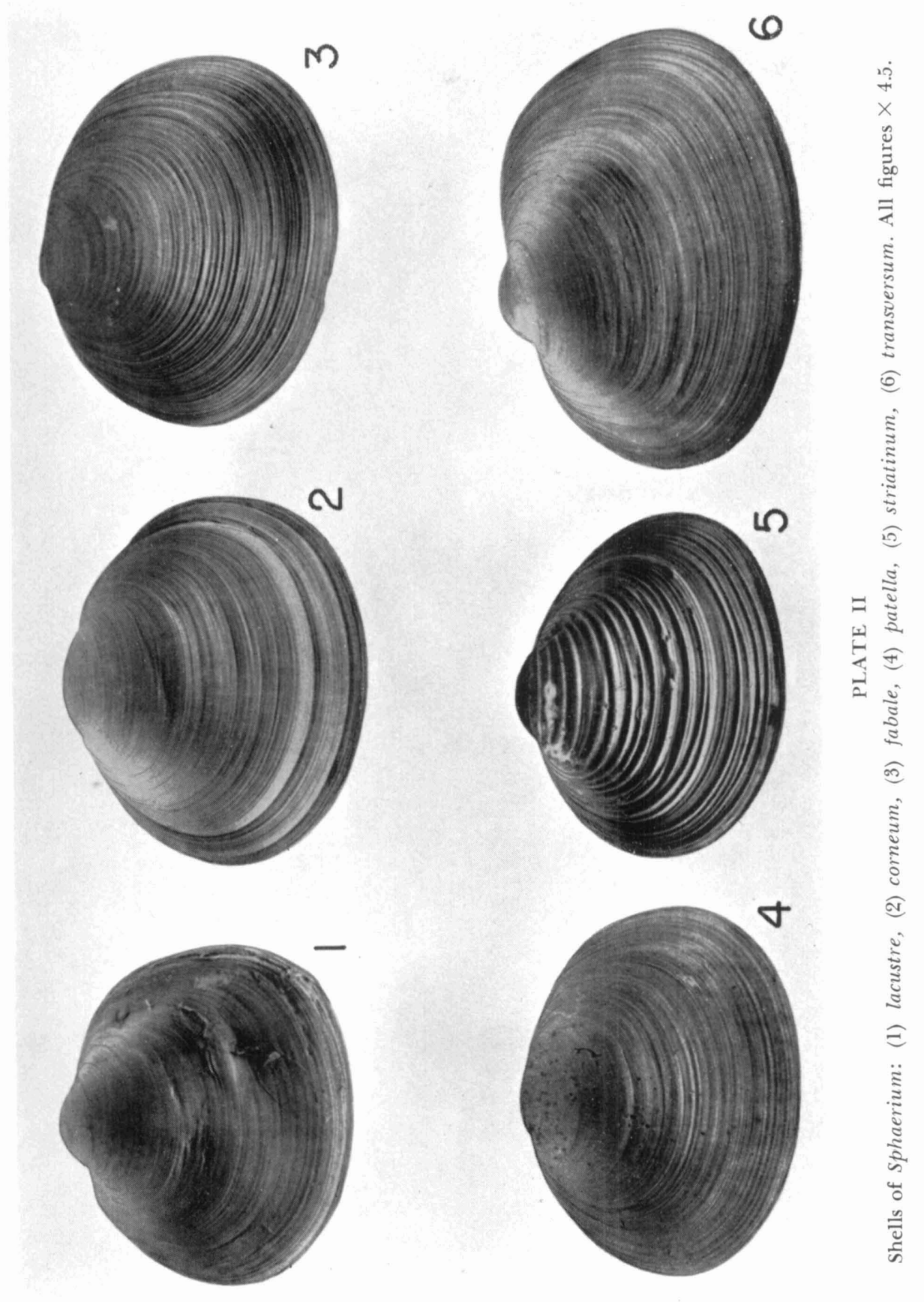



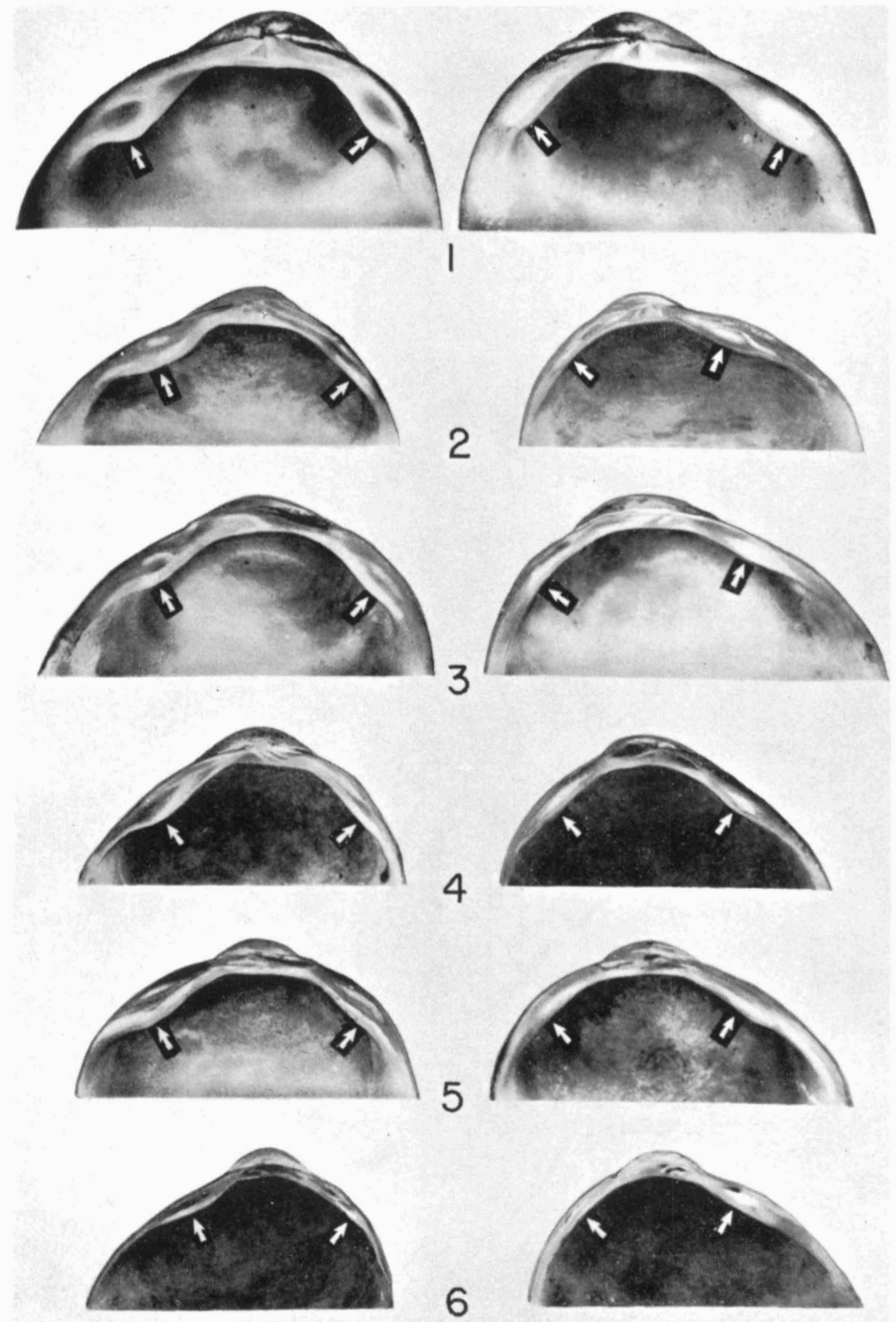

PLATE III

Hinges of Pisidium: (1) dubium, (2) amnicum, (3) idahoense, (4) variabile, (5) adamsi, (6) walkeri. Figures 1-3, $\times 6.5$; figures $4-6, \times 10$. 

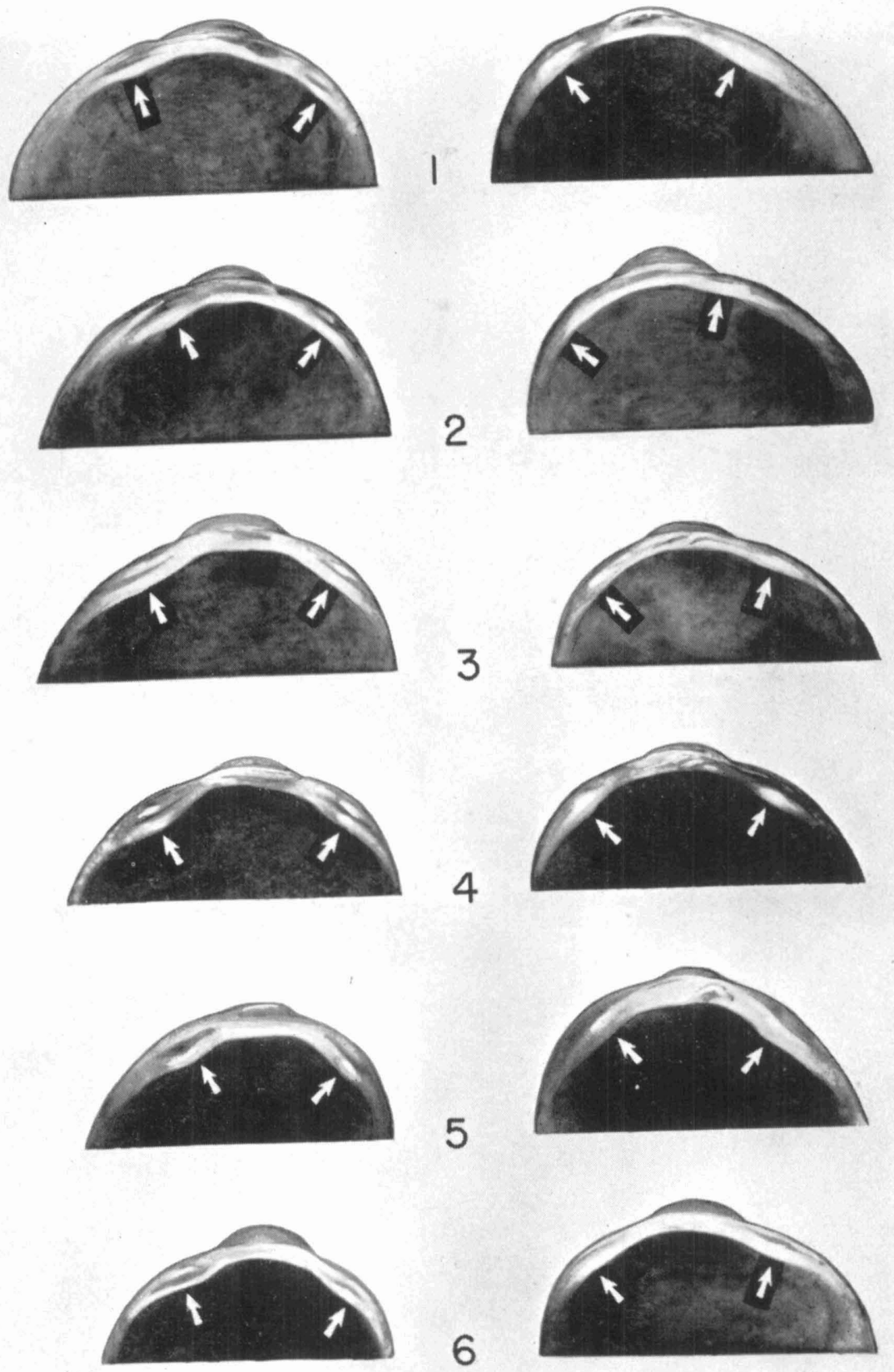

PLATE IV

Hinges of Pisidium: (1) casertanum, (2) lilljeborgi, (3) milium, (4) obtusale, (5) fallax, (6) ferrugineum. Figures $1,3,4,5$, and 6 , $\times 15$; figure $2, \times 12.5$. 

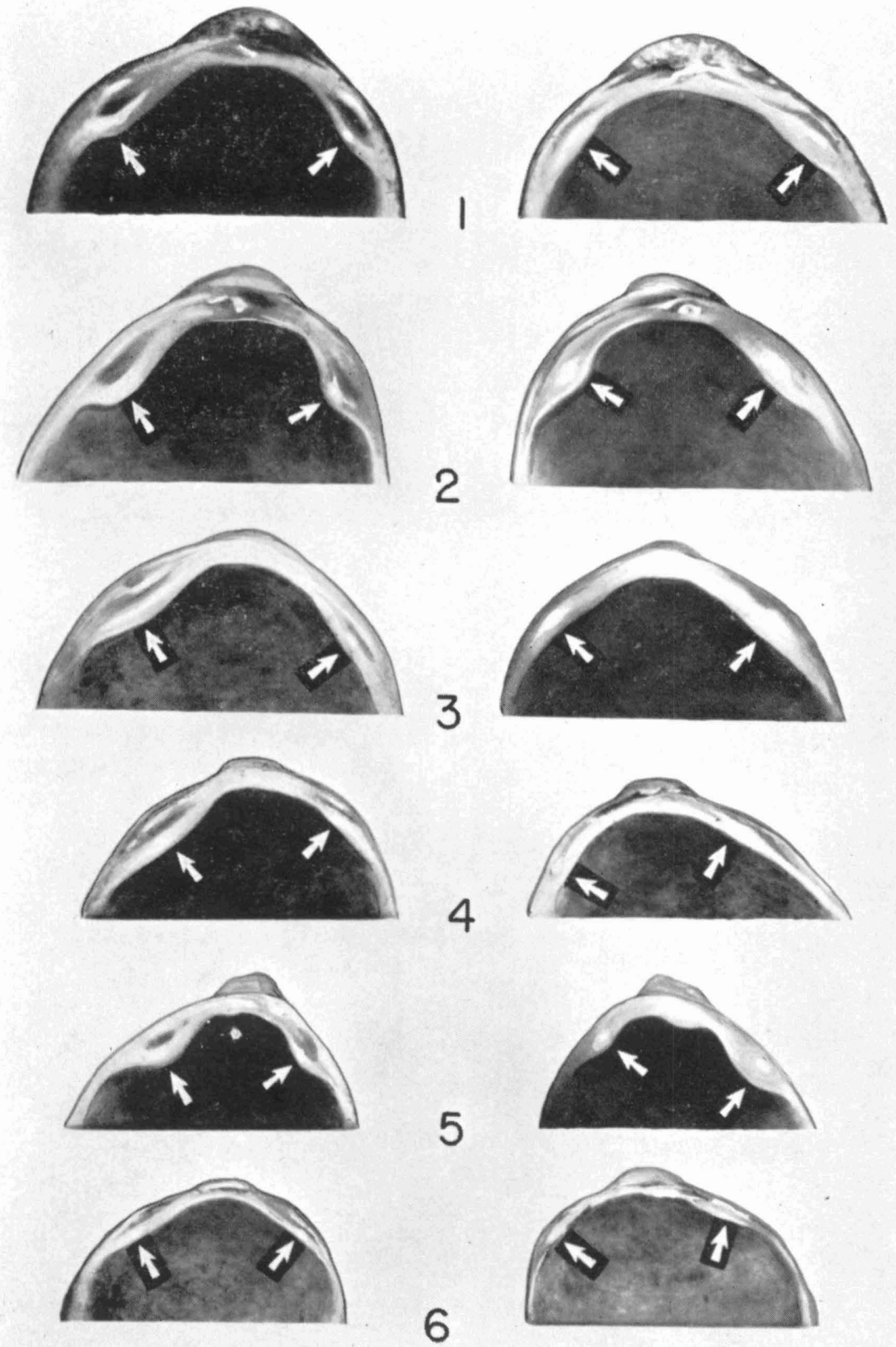

PLATE V

Hinges of Pisidium: (1) aequilaterale, (2) compressum, (3) ultramontanum, (4) henslowanum form supinum, (5) cruciatum, (6) nitidum. Figures 1 and 5, $\times 17$; figures $2,3,4$, and $6, \times 13$. 

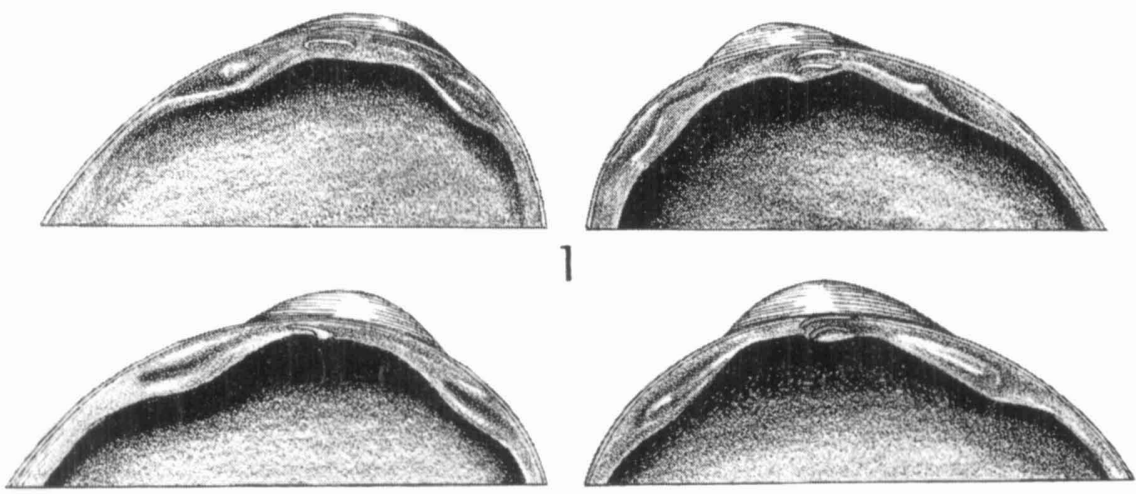

2
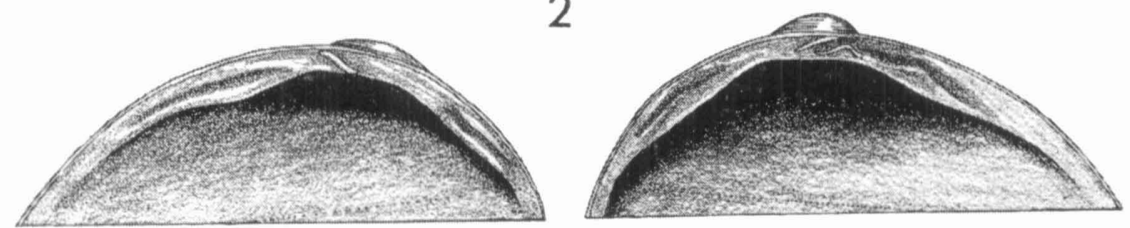

3
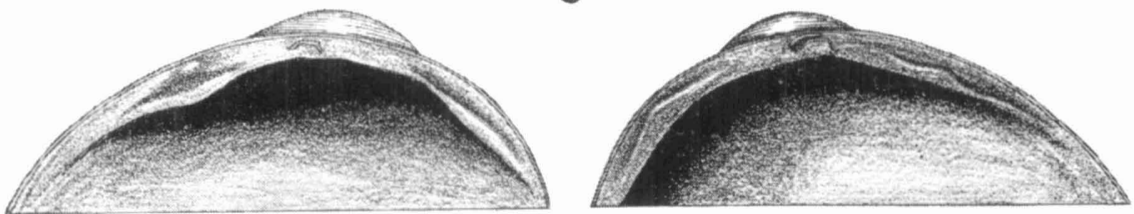

4
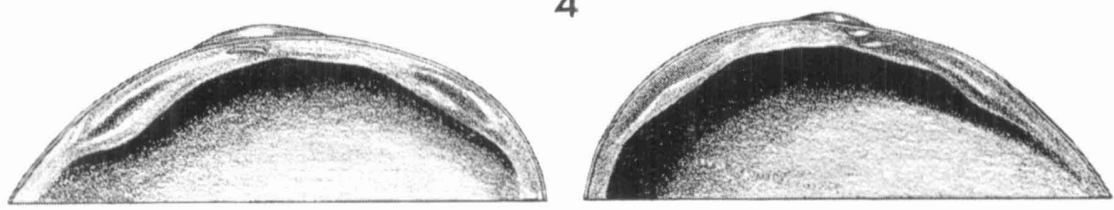

5
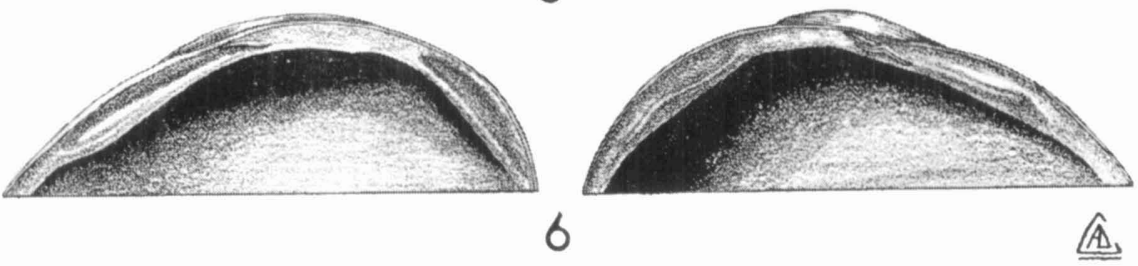

PLATE VI

Hinges of Pisidium: (I) subtruncatum, (2) punctiferum, (3) henslowanum, (4) walkeri form mainense, (5) insigne, (6) conventus. Not to scale. 


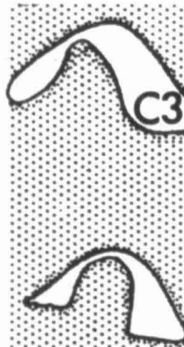

\section{2}

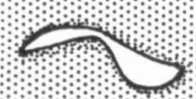

3
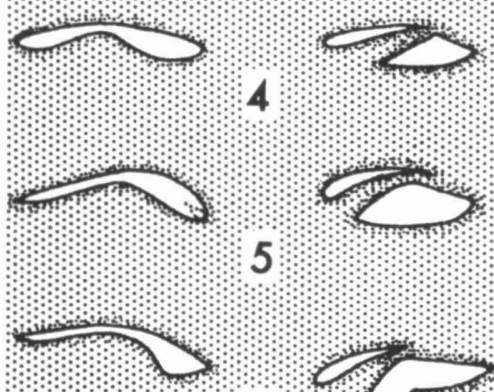

6
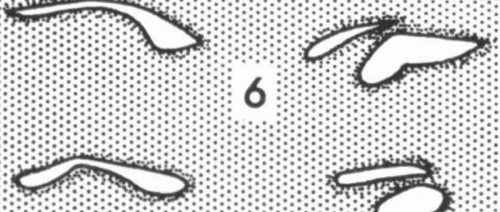

7
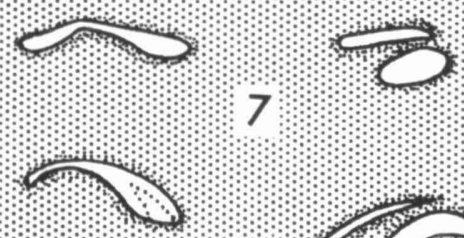

8
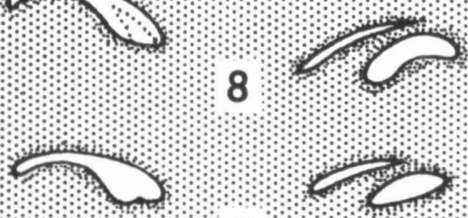

9
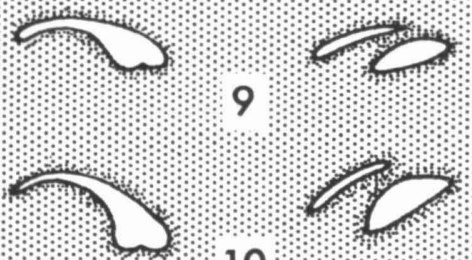

10

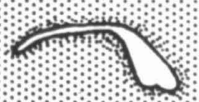

11
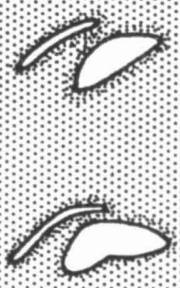

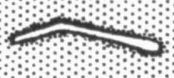

12
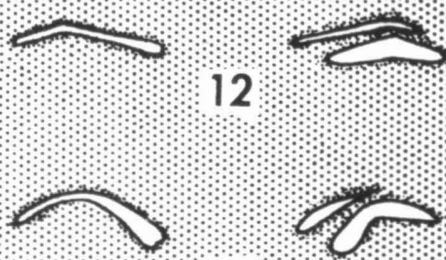

13
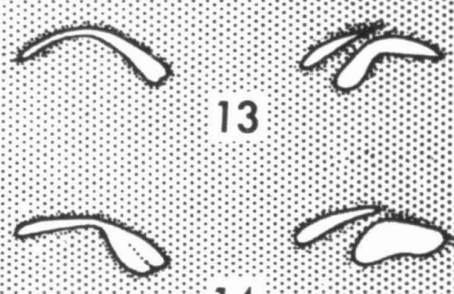

14
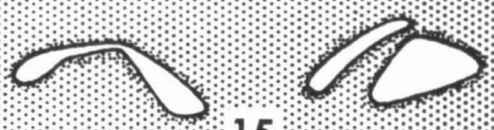

15

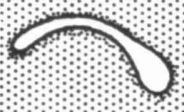

16
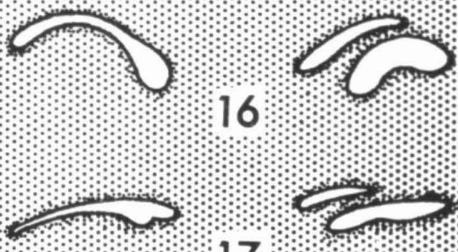

17
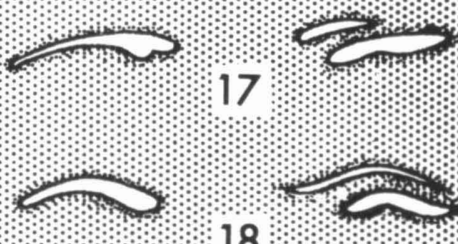

18

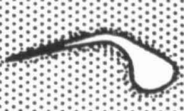

19
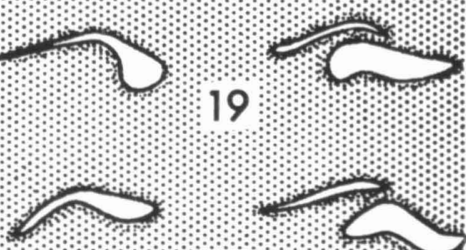

20

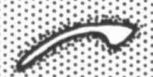

21
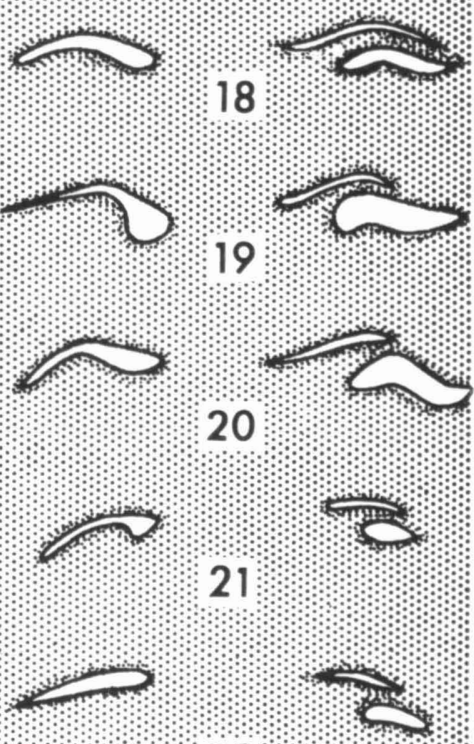

22

$J$ B.B

PLATE VII

Cardinal teeth of Pisidium: (1) dubium, (2) amnicum, (3) idahoense, (4) variabile, (5) adamsi, (6) walkeri, (7) casertanum, (8) lilljeborgi, (9) milium, (10) obtusale, (11) fallax, (12) ferrugineum, (13) aequilaterale, (14) compressum, (15) ultramontanum, (16) cruciatum, (17) nitidum, (18) subtruncatum, (19) punctiferum, (20) henslowanum, (21) insigne, (22) conventus. Not to scale. 




